\title{
Article
}

\section{Toward a Theory of Effective Supranational Adjudication}

\author{
Laurence R. Helfer ${ }^{\dagger}$ \\ Anne-Marie Slaughter ${ }^{\dagger \dagger}$
}

\section{CONTENTS}

I. The Measure of Success: Defining "EFFective" Supranational. ADJUDICATION . . . . . . . . . . . . . . . . . . . . . . . . . . 282

A. Defining Effective Adjudication by Domestic Courts . . . . . . 282

B. Assessing the Effectiveness of International Adjudication . . . 284

C. Defining Effective Supranational Adjudication . . . . . . . . 287

II. THE STORY OF EUROPE . . . . . . . . . . . . . . . . . . . . . . 290

A. The European Court of Justice . . . . . . . . . . . . . . . . 290

B. The European Court of Human Rights . . . . . . . . . . . 293

C. The European Courts Compared . . . . . . . . . . . . 297

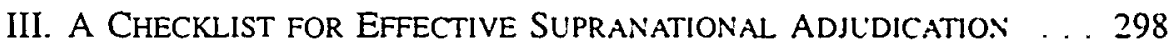

A. A Methodological Note . . . . . . . . . . . . . . . . . 298

B. The Checklist . . . . . . . . . . . . . . . . . . . . 300

1. Factors Within the Control of States Part) to an Agreement Establishing a Supranational Tribunal . . . . . . 300

$\dagger$ Associate Professor of Law, Loyola Law Sihool. Los Angeles

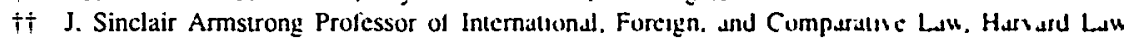
School. We are gratelul to Amanda Frost, Stephen Frug. Stusn Gnder. Amir Licht, Shatun Kasuk. Mittum Porter, Tamar Shapiro, and Tim Wu for restearch assislance Lyonelte Louls-Jacques. Foreign and Intemational Law Reference Librarian at the University of Chicago Sthool ol Law. and Stephen Wiles ot the International Legal Studies Library at Harvard Luw School were also indelalugable in tracking down sources. Joseph H.H. Weiler provided inspiration and encouragement at a cntical pount We also wish to thank Rober Wintemute for comments on an earlier dralt and Marths Minow and Henry Steiner lor particularly helpful comments at a Harvard Law School faculty lunch 

a. Composition of the Tribunal .............. 300
b. Caseload or Functional Capacity of the Court . . . . . 301
c. Independent Factfinding Capacity . . . . . . . . . 303
d. Formal Authority or Status as Law of the Instrument That the Tribunal Is Charged with Interpreting and Applying 304

2. Factors Within the Control of the Judiciary . . . . . . . 307
a. Awareness of Audience . . . . . . . . . . . . 308
b. Neutrality and Demonstrated Autonomy from Political Interests . . . . . . . . . . . . . . . . 312
c. Incrementalism . . . . . . . . . . . . . 314
d. Quality of Legal Reasoning ............. 318
e. Judicial Cross-Fertilization and Dialogue . . . . . 323
f. Form of Opinions ................. 326

3. Factors Often Beyond the Control of States or Judges . . 328

a. Nature of Violations . . . . . . . . . . . . . . 329

b. Autonomous Domestic Institutions Committed to the Rule of Law and Responsive to Citizen Interests . . . . . . 331

c. Relative Cultural and Political Homogeneity of States Subject to a Supranational Tribunal . . . . . . . . 335

C. Reviewing the Checklist ............... 336

IV. APPLYING THE CHECKLIST TO THE UNITED NATIONS

Human Rights CoMmitTeE . . . . . . . . . . . . . . . . . . . 337

A. An Overview of the Committee . . . . . . . . . . . . 338

1. The Reporting Process ................ 338

2. General Comments . . . . . . . . . . . . . . . . . 340

3. The Petition System ... . . . . . . . . . . 341

B. Toward an Increasingly Judicial Approach to the

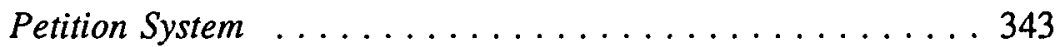

1. Factors Principally Within the Control of States Parties . . 345

a. Composition of the Tribunal . . . . . . . . . . . 345

b. Case Load or Functional Capacity of the Tribunal . . 347

c. Independent Factfinding Capacity . . . . . . . . . . 349

d. Formal Authority or Status as Law . . . . . . . . . . 351

2. Factors Within the Control of the Tribunal ........ 352

a. Awareness of Audience . . . . . . . . . . . 352

b. Neutrality and Demonstrated Autonomy from Political Interests . . . . . . . . . . . . . . . 353

c. Incrementalism and Awareness of Political Boundaries 355

d. Quality of Legal Reasoning . . . . . . . . . . . 356

e. Judicial Cross-Fertilization and Dialogue . . . . . 358

f. Form of Opinions ................. 361

3. Factors Often Beyond the Control of States or Judges . . 362 
a. Nature of Violations . . . . . . . . . . . 362

b. Autonomous Domestic Institutions Committed to the Rule of Law and Responsive to Citizen Interests . . . . . 363

c. Cultural and Political Homogeneity .......... 365

C. Summing Up the Commitlee's Performance Under the Checklist 365

V. A PRESCRIPTION FOR ENHANCING THE EFFECTIVENESS OF THE HUMAN RIGHTS COMMITTEE: CONVERGING WITH THE ECHR IN A GLOBAL COMMUNITY of LAW . . . . . . . . . . . 366

A. Elements of a Community of Law . . . . . . . . . . . . . . 367

B. Building a Global Community of Law . . . . . . . . . . . . . 370

C. A Modest Proposal: Dialogue and Comvergence Between the European Human Rights Tribunals and the Committee . . . . 373

1. Thoughtful Convergence ... . . . . . . . . . . 373

2. A Bounded Framework for Divergence . . . . . . . . . 376

a. Differences in the Rights Protected by the Two Treaties 377

b. Divergence Where Object and Purpose Differ . . . . 378

i. Reference to Democratic Principles . . . . . . . . 379

ii. Teleological Methods of Interpretation . . . . . . 382

3. Divergence from a "European Gloss" on Human Rights . 384

4. Divergence Where the Committee Improves on European

Precedents . . . . . . . . . . . . . . . . 385

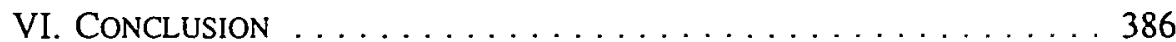


Supranational adjudication in Europe is a remarkable and surprising success. Over the past few decades, it has become increasingly clear that the European Court of Justice (ECJ) and the European Court of Human Rights (ECHR) have convinced national governments, individual litigants, and the European public to endorse and participate in frequent and often high-stakes adjudication at a level above the nation-state. Both tribunals began their existence as creatures of classic public international law, established by treaties-the Treaty of Rome ${ }^{1}$ and the European Convention for the Protection of Human Rights and Fundamental Freedoms (the Convention) ${ }^{2}$-and perched atop national governments and national law with no direct relationship to either. ${ }^{3}$ Somehow, however, through a combination of perspicacity, foresight, and tenacity, both tribunals developed successful strategies to make their judgments as effective, for the most part, as national court rulings. ${ }^{4}$

The central question motivating this Article is whether the success of supranational adjudication in Europe can be translated or transplanted to other regions of the globe. Alleged obstacles are easy to find. ${ }^{5}$ The nations of Western Europe that form the core of the European Union and the Council of Europe are established liberal democracies with strong domestic traditions of the rule of law. ${ }^{6}$ They also share a common core of social, political, and legal values that European jurists themselves have linked to the effectiveness of the two tribunals. ${ }^{7}$ Their hopes for economic integration and their determination

1. Treaty Establishing the EuRopean ECONOMIC COMmUNITY, Mar. 25, 1957, 298 U.N.T.S. 11 (1958) [hereinafter TREATY OF ROME].

2. Nov. 4, 1950, 213 U.N.T.S. 222 [hereinafter Convention].

3. Both European tribunals were originally established as "international" tribunals in the sense that they were created by intergovernmental agreements and charged with interpreting and applying those agrecments as international law. The impact of their decisions on domestic law was intended to be a function of the actions of the states party to those agreements.

4. See infra Sections II.A-B (discussing compliance with ECJ and ECHR rulings).

5. For example, Jost Delbrueck argues:

[T] he regional experience of today is of such a particular nature, made in more or less culturally and politically homogeneous regions, that it hardly could be taken as a model that could be easily transferred elsewhere and that could thereby possibly make a universal approach to the implementation of human rights obsolete.

Jost Delbrueck, International Protection of Human Rights and State Sovereignty, 57 IND. L.J. 567, 576 (1982).

6. See Michael W. Doyle, An International Liberal Community, in RETHINkING AMERtCA's SECURITY: BEYOND COLD WAR TO NEW WORLD ORDER 307, 329-31 (Graham T. Allison \& Gregory F. Treverton eds., 1992); Michael W. Doyle, Kant, Liberal Legacies, and Foreign Affairs, 12 PHIL. \& PUB. ArF. 205, 206-09 (1986) [hereinafter Doyle, Foreign Affairs]. Doyle defines liberal democracies as having four major characteristics: (1) protection of private property; (2) a market economy; (3) equality under the law and respect for human rights; and (4) a representative government deriving its authority from the consent of individuals. See Doyle, Foreign Affairs, supra, at 206-09.

7. As Judge Rudolf Bernhardt of the ECHR states:

The main reason for the effectiveness of the European Convention and the Court is the considerable measures of homogeneity among European states. The member states of the Council of Europe and the parties to the Convention have recognized that the interpretation and the application of the European Convention can contribute to uniform European standards... . [T]here is a feeling among the member states that there exists a common European standard and that this standard should be further developed. 
to safeguard basic human rights were rooted in the searing experience of two world wars. These conditions do not hold for the global community of nations; ${ }^{8}$ they may well be absent even for geographically linked nations in other regions."

Yet, what impact, if any, do these factors have on successful supranational adjudication? We suggest that a critical component of the ECJ's and the ECHR's success is the distinctive nature of their jurisdiction. Although both tribunals have the power to adjudicate state-to-state disputes-the province of traditional international adjudication-each has compiled a more successful compliance record in cases involving private parties litigating directly against state governments or against each other. We define adjudication of these cases as supranational adjudication and jurisdiction over these categories of cases as supranational jurisdiction. The provisions for such jurisdiction in the founding documents of both tribunals provide a point of departure for penetrating the surface of the state, allowing the tribunals to interact directly with the principal players in national legal systems. ${ }^{10}$ Further, stripping the state of its unitary facade creates the possibility of direct relationships between the tribunals and different governmental institutions such as courts, administrative agencies, and legislative committees. The result, at least in Europe, has been the emergence of a "community of law": a partially insulated sphere in which legal actors interact based on common interests and values, protected from direct political interference.

The simple provision of supranational jurisdiction, however, is not a guarantee of effective adjudication. We contend that the European tribunals have been at least the partial architects of their own success and that their experience can form the basis of a potentially universalizable model. What is needed is an actual theory of effective supranational adjudication, an effor to isolate the various factors that have contributed to the European success story and to identify those that can be replicated beyond Europe. Developing such

Rudolf Bemhardt, Commentay: The European System, 2 CONN J INT'L L 299. 299-300 (1987), see also Henry G. Schermers, International Human Rigitss in the European Comumunn and in the Natuons of Central and Eastern Europe: An Ovenview. 8 CONN. J INT'L L 313. 319 (1993) ("In the internal debates in the [ECHR] the legal approach to problems by the different members is very similar Ideds abuut issues like a fair trial, a reasonable time, or the protection of private life are very much the same amongst all lawyers in Westem Europe.").

8. Cf. Rosalyn Higgins, The United Nations: Stll a Force for Peace. 52 MOD L Rrv I. 8 (1989) ("What may be an appropriate and sensitive interpretation for the Western European democraties is not necessarily so for a global system embracing highly diverse polutucal and economic systems ")

9. See Andrew Moravcsik, Explaining International Hunan Rights Regunes Leberal Thicon and Western Europe, 1 EUR. J. INT'L REL. 157, 159, 178-80 (1995) (examining conditions under which effective human rights regimes are likely to emerge and concluding that the relative suctess of the European regime is best explained by factors internal to the countnes concerned)

10. The ECJ has a direct link to individual citizens through the Artucle 177 provision of the Trealy of Rome, allowing national courts to refer cases brought by indwiduals to the ECJ in c.dses involving questions of European Community law. See TREATY OF ROME an. 177 The ECHR has such a link through the right of individual petition first to the European Commission of Human Rights (the Cummission) and then through the Commission to the Court. See, e.g., infra Subsection III B 2 a 
a theory first requires defining "effective" supranational adjudication as precisely as possible. We define effective adjudication in terms of a court's basic ability to compel or cajole compliance with its judgments. In the supranational context, effective adjudication depends on a supranational tribunal's ability to secure such compliance by convincing domestic government institutions, directly and through pressure from private litigants, to use their power on its behalf.

The next step is to distill the factors that observers of and participants in ECJ and ECHR adjudication have identified as common elements in the two

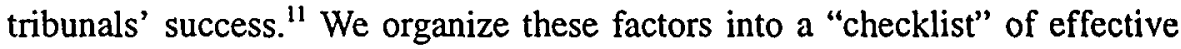
supranational adjudication, categorizing and ranking them in rough order of their presumed importance. We make no effort to test these factors systematically, a process that would require expanding the range of tribunals examined, ensuring variation in their relative performance, and controlling across factors. We instead offer the checklist primarily as a distillation of current knowledge and as a starting point for further research into these and other tribunals.

Even as a preliminary effort, however, the checklist should prove a useful tool for at least a rough assessment of the effectiveness of other supranational tribunals relative to the ECJ and the ECHR. States around the world have increasingly recognized the right of private parties to bring claims against them before supranational tribunals and adjudicatory bodies. ${ }^{12}$ This trend is

11. By focusing on the ECHR, we do not mean to exclude the abundant decisional law of the Commission, a quasi-judicial tribunal that screens claims by individuals before they may be appealed to the court. Under a revision to the European Convention expected to take effect in the next one to two years, however, the Commission will be abolished and will be replaced by a permanent court that, for the first time, individuals can access directly. See infra notes $92-98$ and accompanying text (discussing the structurc of claims under the European Convention and Protocol No. 11).

12. United Nations treaty bodies that are authorized to hear claims against governments by private parties include the Human Rights Committee, the Committee on the Elimination of Race Discrimination, and the Committee Against Tonure. See generally Andrew Bymes, The Committee Against Torture, in THB UNITED Nations and Human Rights 509 (Philip Alston ed., 1992); Karl Joseph Partsch, The Committee on the Elimination of Racial Discrimination, in THE UNITED NATIONS AND HUMAN RIGHTS, supra, at 339; infra Part IV (discussing the Human Rights Committee). The Committee on the Elimination of All Forms of Discrimination Against Women cannot as yet receive communications from individuals but has recommended that an optional protocol to the Convention on the Elimination of All Forms of Discrimination Against Women be drafted. See Andrew Bymes \& Jane Conners, The Adoption of a Petition Procedure Under the Convention on the Elimination of All Forms of Discrimination Against Women, 21 BROOK. J. LNT'L L. 679 (1996).

Under Chapters 11 and 19 of the North American Free Trade Agreement (NAFTA), private partics may seek review from supranational panels to resolve investment-related and antidumping disputes with foreign national governments and administrative agencies. See David Lopez, Dispute Resolution Under NAFTA: Lessons from the Early Experience, 32 TEX. INr'L L.J. 163, 173-84 (1997); Alexandra Maravel, Constructing Democracy in the North American Free Trade Area, 16 J. INr'L Bus. 331, 334-45 (1996). Similar, although not identical, review was available under the Canada-United States Free Trade Agrecment. See Jonathan T. Fried, Two Paradigms for the Rule of International Trade Law, 20 CAN.-U.S. L.J. 39, 4749 (1994); Andreas F. Lowenfeld, Binational Dispute Under Chapter 19 of the Canada-United States Free Trade Agreement: An Interim Appraisal, 24 N.Y.U. J. INT'L L. \& POL. 269 (1993).

The ad hoc panels and the standing appellate body recently established within the World Trado Organization (WTO) may currently entertain trade and trade-related disputes only between governments, 
particularly evident in international human rights law. ${ }^{13}$ Human rights law is a particularly suitable area for testing the generalizability of the European experience with supranational adjudication because the global and regional human rights regimes protect common legal norms that, on the whole, are grounded upon identical or substantially similar treaty texts. ${ }^{\text {is }}$

We thus proceed in the second half of the Article to apply the checklist to the United Nations Human Rights Committee (the Committee or the UNHRC), an eighteen-member panel of experts that issues nonbinding "views" indicating whether a state has violated the International Covenant on Civil and Political Rights (ICCPR or the Covenant). ${ }^{15}$ Under the First Optional Protocol to the Covenant (the Optional Protocol), ${ }^{16}$ states parties may authorize individuals alleging human rights violations to file complaints against the states directly with the Committee. Since its first meeting in 1977, the Committee has established, through a slow accretion of case law, a more precise understanding of global human rights norms in a variety of complex factual settings.

Although the Committee is the most active global counterpart to the European human rights tribunals, its work is far less well-known to scholars, litigants, and human rights activists, and its success as a supranational

but commentators have already argued in favor of grantung standing to pnvate and other nongovemmental parties. See G. Richard Shell, Trade Legalism and International Relatons Theon" An Analysus of the World Trade Organization, 44 DUKE L.J. 829, $911-22$ (1995); Glen T. Schleyer, Notc. Power to the People: Allowing Private Parties To Raise Claims Before the WTO Dispute Resolution System, 65 Fok1)HAt L REV, 2275 (1997).

13. For the purposes of this Aricle, we have limited our focus to the civil and politucal liberies that comprise the "first generation" of international human rights. It is only for this calegory of nghts that states have developed complaint procedures permitting individuals to seck review of governmental practices before imparial international tribunals and review bodies. Even in Europe. "second" and "Uhurd" generation human rights, which include social, economic, cultural, development, and group-based nghts, see Brenda Cossman, Reform, Revolution, or Retrenclument? Internasıonal Hunan Rights ith the Post.Cold War Era. 32 HARV. INT'L L.J. 339, 344 \& n.18 (1991), have not yet become subject to even a limited form of supranational adjudication. See Protocol Amending the European Social Charter Providing for a System of Collective Complaints, opened for signature Nov. 9, 1995. Europ. T.S No. 158. 34 1.L.M 1453 As of June 1997, this protocol had been ratified by only two states and had not yet entered into force See Councll of Europe, Chart of Signatures and Ratifications of European Treatifs. June 6. 1997 Update [hereinafter CHART OF SIGNATURES 1997].

14. See infra Section V.C (comparing rights protected by the Intemational Covenant on Civil and Political Rights to those protected by the European Convention)

15. International Covenant on Civil and Political Rights and Optronal Protocol, adopted Dec 16, 1966, G.A. Res. 2200, U.N. GAOR, 2I st Sess., Supp. No. 16, at 52. 59. U.N Doc. A/6316 (1966), 999 U N TS 171, 301 (1967) (entered into force Mar. 23, 1976) (hereinafter Covenant and Optional Protocol. respectively]. The Covenant is also known as one pant of the "Intemational Bill of Rights" See THE INTERNATIONAL BILL OF RIGHTS: THE COVENANT ON CIVIL AND POLTICAL RIGHTS (Louis Henkin ed. 1981) [hereinafter THE INTERNATIONAL BILL OF RIGHTS]; cf. MANFRED NOWAK. U.N COVENANT ON CVVIL AND POLITICAL RIGHTS: CCPR COMMENTARY al xvii (1993) (refernng to the Universal Declaration of Human Rights, the Covenant on Civil and Political Rights, and the Covenant on Economic. Soctal and Cultural Rights as the "International Bill of Human Rights"). As of April 1997, 136 states had ratufied the Covenant, and 86 states had ratified the Optional Protocol. See UNTtEo NATIONS. ECONONIC ANd SOCLAL COUNCIL, HUMAN RIGHTS COMMITTEE, PRESS RELEASE: HuMAN RIGHTS COMMITTEE CONCLUdeS ThREEWEEK HEADQUARTERS SESSION, U.N. Doc. HR/CT/494 (1997) (hereinafter HuMAN RIOHTS COMMITTEE PRESS RELEASE].

16. Optional Protocol, supra note 15. 
institution (including the record of compliance with its decisions) is far less certain. ${ }^{17}$ Recently, however, the Committee's activities have sparked renewed interest. ${ }^{18}$ Emboldened by the success of regional regimes, by the end of the Cold War and the rise of fledgling democracies in Eastern Europe, and by several recent high-profile cases, commentators have begun to explore whether a legally binding individual complaint procedure can be replicated at the global level. Some of their proposals have focused on creating new institutions, ${ }^{19}$ and others have considered whether the Optional Protocol should be amended to permit the Committee to issue legally binding opinions similar to the judgments of the ECHR. ${ }^{20}$

Measuring the Committee's performance against the various factors enunciated in the checklist reveals an important trend: In numerous and diverse ways, the Committee, even without the power to issue legally binding judgments, is behaving more and more like a court. Although by no means a court in the formal sense and lacking many of the institutional characteristics possessed by the ECJ and the ECHR, the Committee has, within the limits of

17. See HenRy J. Steiner \& PHILIP Alston, INTERnational human Rights IN CONTEXT: LaW, POLITICS, MORALS 550 (1996) ("The record of compliance by states with views rendered by the Committce under the Optional Protocol is patchy."); TOM ZWART, THE ADMISSIBILTTY OF HUMAN RIOHTS PETITIONS 22 (1994) (noting that prior to 1990 the UNHRC "received a growing number of complaints from victims stating that no appropriate remedy had been provided by the State party concerned" and that as a result the Committee adopted new procedures to monitor compliance with its views); see also DoMINIC MCGOLDRICK, THE HUMAN RIGHTS COMMITTEE 504 (1991) ("It is very oifficult to provide positive cvidence that the existence of the Covenant and the work of the HRC is having any concretc and positive effect on the human rights position in the States parties."); Torkel Opsahl, The Human Rights Commitfee, in THE UNITED NATIONS AND HUMAN RIGHTS, supra note 12, at 369, 437 (identifying "the absence of direct and effective fact-finding" as a "basic weakness in the system" and linking such absence to the ineffectiveness of the UNHRC). McGoldrick goes on to urge that the Committee document carcfully all instances of compliance. See MCGoLDRICK, supra, at 504.

18. See Manfred Nowak, The Activities of the UN-Human Rights Committee: Developments from I August 1989 Through 31 July 1992, 14 HUM. RTS. L.J. 9, 10 (1993) (hereinafter Nowak, UNHRC Activities] ("The growing importance of human rights in general and of the Covenant in particular is ... reflected by a steady expansion of the legal literature on this subject." (emphasis omitted)); Manfred Nowak, UN-Human Rights Committee: Survey of Decisions Given up till July 1989, 11 HUM. RTS. L.J. 139, 152 (1990) ("The comparably high number of communications against Western industrialized countries shows that lawyers are increasingly aware of this individual communication procedure being available in addition to or as an altemative to the one under the European Convention on Human Rights.").

19. In a recent law review article, for example, John Barton and Barry Carter suggest that the United States should "push[] for a global umbrella organization comprised of all those democracies willing to submit themselves to the type of international judicial human rights review now available in Europe." John H. Barton \& Barry E. Carter, International Law and Institutions for a New Age, 81 GEo. L.J. 535, 557 (1993). The key feature of such an organization, they argue, is that the human rights protections it provides "should be important and strict; countries should only be allowed to join if they are willing to accept formal legal surveillance, and there should be an effective enforcement mechanism that allows individuals to initiate cases and to have at least a role in pursuing their case." Id.

20. See Markus G. Schmidt, Individual Human Rights Complaints Procedures Based on United Nations Treaties and the Need for Reform, 41 INT'L \& COMP. L.Q. 645, 650 \& n.17 (1992); see also Thomas Buergenthal, International Human Rights Law and Institutions, 63 WASH. L. REV. 1, 13 (1988) (noting the weak powers of the Committee but stressing the importance of "pushing for impartial international human rights institutions with judicial and quasi-judicial powers"). But see Nisuke Ando, The Future of Monitoring Bodies-Limitations and Possibilities of the Human Rights Committee, 1991-1992 CAN. HUM. RTS. Y.B. 169, 172 (arguing that it may be premature to expect states parties to authorize the Committee to issue legally binding decisions). 
its powers, followed an increasingly judicial method of operation. Its efforts to enhance its effectiveness as a supranational tribunal will remain handicapped by a number of factors on the checklist that are either within the control of the states party to the Covenant or inherent in the universal scope of its jurisdiction; nevertheless, it is moving in the right direction with respect to the factors within its control.

We conclude by proposing a strategy whereby the UNHRC could enhance its effectiveness further by helping to construct a global community of law. We recommend that Committee members engage in an active dialogue with the ECHR and the European Commission of Human Rights (the Commission) as the first step toward a broader effort to increase communication with both national and supranational courts and tribunals over the interpretation and evolution of human rights norms. In particular, we propose that the Committee adopt a policy of thoughtful convergence with European jurisprudence, supplemented by informed divergence from that jurisprudence based on specific and articulated reasons.

Part I discusses effective domestic adjudication, distinguishes between international and supranational adjudication, and defines effective supranational adjudication. Part II recounts the "story of Europe," summarizing the successes achieved by the ECJ and the ECHR over the last forty" years and focusing on the methods used by both tribunals to build a constituency among the individuals, lawyers, interest groups, and national courts that refer cases to them. Part III develops the checklist, dividing factors into those within the control of states responsible for establishing a supranational tribunal, those within the control of the tribunal itself, and those that are arguably beyond the control of either. Part IV applies the checklist to the recent practice and procedure of the UNHRC. Finally, Part V elaborates the principal elements of a community of law as it has evolved in Europe. It also describes the recent increase in communication and interaction among national and supranational courts and tribunals that could mark the beginnings of a global community of law. This final part also outlines our proposal for structured interaction between the UNHRC and its European counterparts.

Taken as a whole, this Article seeks to contribute to the existing literature along three different dimensions. First, we hope that the preliminary model of effective supranational adjudication developed here will spur the gathering of additional data from the experience of other supranational tribunals, tribunals concerned with diverse substantive areas of the law and exercising jurisdiction over many different groups of countries. At a time when the right of individual petition is spreading rapidly, both to other human rights tribunals and to various entities charged with resolving trade-related disputes, effors to develop such a model are both timely and important. Second, we use our model to develop a concrete proposal for improving the effectiveness of the UNHRC and thus to strengthen hopes for proceeding simultaneously along regional and 
universal tracks to strengthen the global protection of human rights. Third, we develop the concept of a global community of law, constituted not by a world court but rather by overlapping networks of national, regional, and global tribunals. By communicating with one another in a form of collective deliberation about common legal questions, these tribunals can reinforce each other's legitimacy and independence from political interference. They can also promote a global conception of the rule of law, acknowledging its multiple historically and culturally contingent manifestations but affirming a core of common meaning.

\section{The Measure of SuCCESS: \\ DEFINING “EFFECTIVE” SUPRANATIONAL AdJUdication}

Defining effective supranational adjudication first requires defining effective adjudication and supranationalism. The definitions offered here cannot be definitive; both terms are broad and already subject to multiple meanings. Our purpose is instead to develop an agreed upon terminology that is as precise as possible for the analysis that follows.

\section{A. Defining Effective Adjudication by Domestic Courts}

When can adjudication be said to be "effective"? The effectiveness of a particular court or of courts in general quickly becomes intertwined with larger jurisprudential questions such as the nature of law and the sources of compliance. Defining effectiveness also inevitably requires asking the question "effective for what purpose?"- an inquiry that will in turn depend on a prior conception of the functions of specific courts within specific legal systems. These functions can include dispute resolution, "social control,"21 lawmaking, ${ }^{22}$ articulating social and political ideals, ${ }^{23}$ protecting individual and minority rights, and securing social change. ${ }^{24}$ These functions may conflict with one another; they may also each generate a different metric of effectiveness.

21. "Social control" here means the imposition of preexisting rules on disputants. See MARTIN ShaPIRo, Courts: A Comparative AND POlTICAL ANALYSIS 26 (1981).

22. Courts typically make new rules as an inevitable part of their interpretation of existing law. See id. at 28-36.

23. See Eugene V. Rostow, The Democratic Character of Judicial Review, 66 HARV. L. REv. 193, 208 (1952) ("The Supreme Court is, among other things, an educational body, and the Justices are incvitably teachers in a vital national seminar."); see also ALEXANDER M. BICKEL, THE LEAST DANGEROUS BRANCH: THE SUPREME COURT AT THE BAR OF AMERICAN POLITICs 26 (2d ed. 1986) (endorsing and claborating on Rostow's observation). For further discussion, see Christopher L. Eisgruber, Is the Supreme Court an Educative Institution?, 67 N.Y.U. L. REV. 961 (1992).

24. See Abram Chayes, The Role of the Judge in Public Law Litigation, 89 HaRv. L. REV. 1281 , 1288-304 (1976) (describing a model of "public law litigation" in which judges must resolve disputes involving multiple parties, prospective rather than retrospective consequences, and a range of remedies enjoining categories of undesirable social and economic behavior). 
We offer a much more basic definition of effective adjudication. In the first instance, the effectiveness of a particular court rests on its power to compel a party to a dispute to defend against a plaintiff's complaint and to comply with the resulting judgment. This power is the characteristic that typically distinguishes courts from other dispute resolvers such as go-betweens, mediators, and arbitrators. ${ }^{25}$ Thus formulated, this power is one that is exercised during the pendency of a particular dispute and immediately after a dispute is resolved through the issuance of a judgment. The effects of this power are felt ex ante as well as ex post, however, in that paries who are in a similar legal position to actual litigants are likely to comply with the courts judgment "in the shadow" of prospective litigation. ${ }^{26}$

The power of a court to compel parties to appear before it and to comply with its judgments also determines its significance as a political actor. To the extent that it can exercise this power against other govemment institutions, it can change the dimension and scope of the political bargaining space. Domestic debates in the United States about the power of the Supreme Court, for instance, begin from the premise that it is an important actor on the political landscape, equal to Congress and the President. ${ }^{27}$ In this sense, the United States is the "peculiar home of the expansion of judicial power,"

25. See SHAPIRO, supra note 21, at 7. Even in domestic adjudication, however, judictal effectiveness is easy to overestimate. Lawyers and legal scholars are often likely to posit a congruence between paper commands and popular practice. The debate between Abram Chayes, on the one hand. and Theodore Eisenberg and Stephen Yeazell, on the other, illustrates the point. Chayes posits a tradituonal model of "private law litigation" in which the judge issues a reirospective judgment with which parties more or less automatically comply, while Eisenberg and Yeazell point out the frequent noed for judges to issue repeated compliance orders against recalcitrant litigants. Compare Chayes, supra note 24, at 1283. 1285-88, with Theodore Eisenberg \& Stephen C. Yeazell. The Ordinany and the Extraordinan' in Instututional Lutigation. 93 HARV. L. REV. 465, 481-91 (1980).

26. See Robert H. Mnookin \& Lewis Komhauser. Bargainng in the Shadow of the Law: The Case of Divorce, 88 YALE L.J. 950, 968-69 (1979) (arguing that in divorce procecelings the parties' bargaining is a direct result of the "shadow of the law" under which they bargain). It is important to distinguish between the above definition of the power of cours and the power of law generally to compel complance: the latter is a related but larger subject beyond the scope of this Arucle. Legal rules may be obeyed independent of the power of cours, through what H.L.A. Har calls "habits of obedience." H L.A. HART. THE CONCEPT OF LAW 50-60 (1961); see also ARCHIBALD COX. THE ROLE OF THE SUPRENE COURT IN AMERICAN GOVERNMENT 103-04 (1976) (discussing the operation of law without force or whth only a minimum of force against "a few recalcitrants"). Such tranquil vistons are hardly the result only of the effectiveness of cours; they rely also on deeply ingraned histoncal expenence, political design, and collective culture. For an empirical study of complance. soc TOM R. TYLER. WHY PEOPLE OBEY THE LAW (1990).

27. See, e.g., CoX, supra note 26, at 104 (arguing that the Supreme Coun "command[s] atecplane and support not only for its decisions but also for its role in govemmeni"): see also THE GLOBAL EXPANSION OF JUDICLAL POWER (C. Neal Tate \& Torbjom Vallinder eds., 1995) (describing the enhanced policymaking role of cours in different countries around the world, with a particular focus on the rise of judicial power relative to legislative or executive powcr).

28. Marin Shapiro, The United States, in THE Global. Expansion of Judiclal Power, supra note 27, at 43, 43. Rober McCloskey's classic treaument of the Supreme Coun simularly begins with a chapter titled "The Genesis and Nature of Judicial Power." Robert G MCCloskey. The AMierican Supreme COURT 1 (2d ed. 1994). 
phenomenon now being documented around the world. ${ }^{29}$

The power of a court to compel litigants to appear before it and to comply with the resulting judgment stems in part from its ability to harness the coercive power of the state. Supplementing and surrounding this core of potential coercion, however, is the power of legitimacy: a court's ability "to command acceptance and support from the community so as to render force unnecessary." 30

Legitimacy, in turn, is a concept or attribute that often eludes precise definition, more susceptible to subjective perception than to objective measurement. ${ }^{31}$ Various formulations of the sources of judicial legitimacy include the following components, related to both structure and process: impartiality; principled decisionmaking; reasoned decisionmaking; continuity of court composition over time, ${ }^{32}$ consistency of judicial decisions over time; respect for the role of political institutions at the federal, state, and local levels ${ }^{33}$ and provision of a meaningful opportunity for litigants to be heard. This list is not intended to be exhaustive; further, many of the factors overlap. Nevertheless, it offers a sense of the judicial attributes that undergird the "compliance pull" of judicial decisions. ${ }^{34}$

\section{B. Assessing the Effectiveness of International Adjudication}

Assessing the effectiveness of courts, whether domestic or international,

29. See The Global EXPANSION OF Judicial POWER, supra note 27, at 27 (arguing that "there is an expansion of judicial power afoot in the world's political systems"). The volume includes chapters discussing the growth of judicial power throughout Western Europe, as well as in Canada, Scandinavia, Malta, Israel, Australia, several post-communist states, the Philippines, and Namibia. Judicial power in this sense, however, often depends on the granted or assumed power of judicial review of legislation, a power quite distinct from the power to compel compliance that we identify as the linchpin of cffective adjudication.

30. Cox, supra note 26 , at 103 . The question of judicial legitimacy arises in different contexts. Legal scholars in the United States tend to concentrate on the legitimacy of judicial review. See, e.g., BICKEL. supra note 23; Jesse H. ChOPER, Judiclal Review and the National Political Process: A Functional RECONSIDERATION OF THE ROLE of THE SUPREME COURT (1980); JOHN HART ELY, DEMOCRACY AND DISTRUST: A THEORY OF JUdICIAL REVIEW (1980); William A. Fletcher, The Discretionary Constitution: Institutional Remedies and Judicial Legitimacy, 91 YALE L.J. 635 (1982). From this vantage point, judicial legitimacy depends largely on maintaining the proper boundarics between the judiciary and its fellow branches. Equally important, however, is the role of judicial legitimacy in the relationship between the citizen and the state. See, e.g., TYLER, supra note 26 , passim. We attempt to consolidate the two perspectives.

31. A useful overview of the literature on judicial legitimacy is Susan P. Sturm, A Normative Theory of Public Law Remedies, 79 GEO. L.J. 1357, 1390-411 (1991). Cf. BICKEL, supra note 23, at 49 (discussing the importance of procedural justice to legitimacy); TYLER, supra note 26 , at 6, 163-64 (same). A complementary analysis, identifying several of the factors that we list in Pant III with regard to supranational tribunals, is contained in Scott C. Idleman, A Prudential Theory of Judicial Candor, 73 TEX. L. REV. 1307, 1388 (1995). Idleman finds three factors affecting judicial legitimacy: (1) unanimity or near unanimity in decisions; (2) professional civility in opinions; and (3) continuity of the law over timc. See id.

32. See BICKEL, supra note 23 , at $25-31$.

33. See Sturm, supra note 31 , at 1380.

34. Thomas M. Franck, The POWer of Legtrmacy Among Nations 24 (1990). 
is not a binary determination. It instead requires locating courts along a continuum of effectiveness. Applying the criteria set forth above, international dispute resolution tribunals are substantially less effective than most domestic courts. ${ }^{35}$

The problem is relatively straightforward. International tribunals lack a direct coercion mechanism to compel either appearance or compliance. They must rely instead on such factors as the immediate perceived interests of states involved in particular disputes in securing judicial settlements, their own legitimacy and the legitimacy of any particular judgment reached, the strength and importance of the international legal rules goveming a specific dispute, and the general force of normative obligation. In practice, reliance on these mechanisms has been problematic. Consider the following assessment of the International Court of Justice (ICJ) by the authors of a popular American international law casebook:

[T] he [ICJ] has not lived up to the hopes of many of its early supporters that the Court, along with the United Nations, would evolve into an international government. To begin with, 90 cases in almost 50 years is not a heavy caseload .... Moreover, many of the cases have not been of great international importance. And, in more than 20 contentious cases, the Court's jurisdiction . . . was challenged, with the Court dismissing almost half of these cases. When the Court did reach a judgment on the merits, the affected parties have generally complied with it, but there have been exceptions, especially in recent years. ${ }^{36}$

This assessment reflects the problems of international adjudication on several levels. To begin with, states are reluctant to sue one another. The decision to invoke the jurisdiction of an international tribunal, even where it

35. We use the term "international tribunals" to include not only entulies offictally designated "courts," such as the International Coun of Justice (ICJ), but also less formal or permanent bodies established to resolve specific disputes or clusters of disputes. Examples include panels convened under the 1947 General Agreement on Tariffs and Trade (GATT), dispute setuement procedures avaluble under vanous environmental treaties, the underutilized Permanent Coun of Arbitration. and ad hoc interstite sibitration tribunals. See generally David A. Wirth, Reexaminmg Deciston-Making Processes in Internahonal Environmental Law, 79 IOWA L. REV. 769. $779-90$ (1994) (Idenufying inteistate dispute resolution mechanisms).

36. Barky E. Carter \& Phillip R. Thimble, International law 300 (20 ed 199S) Similar problems arose with the interstate dispute seulement system of GATT Under this system. \& GATT member country that lost before a dispute setllement pand could effectively block the adoption by the GATT Council of the panel's repor, thereby preventing the decision from becoming legally binding See JoHs H. JACKSON, RESTRUCTURING THE GATT SYSTEM 66 (1990). Through use of this veto procedure. delaying tactics, or outright recalcitrance, several states, particularly politically powerful industralized nations. refused to adhere to certain GATT panel recommendations. See id. al 67. Kenneth W Abbult. The Uruguay Round and Dispute Resolution: Building a Private-Interests System of Justuce. 1992 COLUM BUS L REV 111,140 . In the years immediately prior to the completion of the Uruguay Ruund. the rate of noncompliance increased. See Emst-Ulrich Petersmann. The Dispute Settlement Sistem of the World Trade Organization and the Evolution of the GATT Dispute Settlement System Since 1948. 31 Comisus MikT L REV. 1157, 1193 (1994). 
is available in the context of a specific dispute, inevitably involves a host of political and legal considerations. As David Wirth has observed in his analysis of compulsory third-party dispute resolution as a mechanism for enforcing international environmental law,

a state whose own performance of international obligations is inadequate may hesitate to proceed against others for fear of calling attention to itself or establishing undesirable precedents. Notwithstanding a meritorious legal claim on an environmental matter, one State may be reluctant to initiate a third-party dispute settlement process against another State for fear of jeopardizing other strategic or economic bilateral relationships. ${ }^{37}$

Further, even once a suit has been filed and the tribunal has determined that it has jurisdiction over both the subject matter and the defending state, the tribunal has no means of compelling the defendant to appear-other than the often hollow threat of a default judgment.

A fresh set of problems arises at the enforcement stage. The mechanisms of coercion available to enforce international judgments are those generally available to states or groups of states to enforce international law against one another. States litigating before the ICJ are formally obligated to comply with its judgments. ${ }^{38}$ Failure by a losing party to comply with a judgment provides the winning party with recourse to the Security Council, which may make recommendations or decide upon measures to be taken to give effect to the judgment. ${ }^{39}$ The same political calculations involved in the initial decision to bring a suit, however, also affect any unilateral or collective decision to undertake such measures. In addition, the use of collective measures such as sanctions raises the standard panoply of collective action problems. ${ }^{40}$

Perhaps the best measure of the relative ineffectiveness of international tribunals is the degree of effort expended by international lawyers to demonstrate that compulsory third-party adjudication is neither a necessary nor a sufficient condition to ensure compliance with international legal regimes. ${ }^{41}$ Louis Henkin dodges the problem with his celebrated assertion: "[A]lmost all nations observe almost all principles of international law and almost all of their

37. Wirth, supra note 35 , at 779; see also Petersmann, supra note 36, at 1169 ("States are often reluctant to initiate inter-state complaints ....").

38. See U.N. CHARTER art. 94, para. 1; Statute of the International Court of Justice, Oct. 24, 1945, art. 59, 59 Stat. $1055,1063$.

39. See U.N. CHARTER art. 94, para. 2 .

40. Indeed, the Security Council has never taken any measures pursuant to these provisions. See CARTER \& TRIMBLE, supra note 36, at 301; cf. Petersmann, supra note 36, at 1185-86 (noting that GATT contracting parties authorized suspension of trade concessions as a result of a GATT panel ruling "only once over the past 45 years").

41. For a review of decades, if not centuries, of scholarship, see Harold Hongju Koh, Why Do Nations Obey International Law?, 106 YALE L.J. 2599 (1997) (review essay). 
obligations almost all of the time."42 Thomas Franck provides a theory of compliance that rests on the independent "compliance-pull" of particular international legal rules and norms based on their degree of legitimacy." Abram Chayes and Antonia Chayes reject the "criminal law model" of forcible enforcement of legal rules by courts as inappropriate for the international legal realm; they develop a "managerial" theory of compliance that emphasizes capacity-building, diplomatic "jawboning," and sustained participation and engagement in international regulatory regimes. " Finally, Harold Koh argues that compliance depends on a "transnational legal process." ".' "Once nations begin to interact," he claims, "a complex process occurs, whereby international legal norms seep into, are internalized, and become embedded in domestic legal and political processes." ${ }^{46}$

\section{Defining Effective Supranational Adjudication}

Defining effective supranational adjudication first requires a definition of supranational, as opposed to international, law and institutions. The term "supranational" has no canonical definition but is typically used to identify a particular type of international organization that is empowered to exercise directly some of the functions otherwise reserved to states. ${ }^{47}$ The distinguishing feature in this regard between supranational and international organizations is the greater transfer of or limitation on state sovereignty involved in the establishment of a supranational organization. ${ }^{\text {t8 }}$ The paradigmatic example of a supranational organization is the European Union. ${ }^{\text {.y }}$

42. Louis N. Henkin, how Nations Behave: LaW and foreign Policy $\$ 7$ (2J ed 1979) (emphasis omitted).

43. FRANCK, supra note 34, at 24; see also infra Subsoction III B.2.d (discussing components of legitimacy).

44. See Abram Chayes \& antonla handler Chayes. The New Sovtheignty Complance with INTERNATIONAL REGULATORY AGREEMENTS 22-28 (1995)

45. Harold Hongju Koh, Transnational Legal Process, 75 NEB L REV 181 (19\%6)

46. Id. at 205.

47. See, e.g., Forest L. GRIEves, Supranationalism and INTERNational adjudication 14 (1969) ("The term 'supranational' signifies that signatory states have transferrod to an internalional instututuon certain limited decision-making powers normally exereised only by the governmental organs of a sovereign state..." (emphasis omitted)). Henry Schermers and Niels Blokber define six "Iundumental characteristics" of a true supranational organization, including the power to make decisions binding an the member states; at least parial independence of the organization from the member states, the ability of the organization to "make rules which directly bind the inhabilints of the member stutes", the "puwer to enforce its decisions"; "some financial autonomy"; and the impossibility of unilateral withdraw, HeNkY G. SCHERMERS \& Niels M. BLOKKER, INTERNATIONAL INSTITUTIONAL LAW $\$ 61$, al 4142 (3d rev cd 1995).

48. Grieves argues that the best way to grasp the distunctuve nalure of supranstional organizitions is to locate them on a spectrum between "loose intemational organization|s|" and "strong Iederal organization[s]." GRIEVEs, supra note 47 , at 13.

49. The original treaty of the European Coal and Stecl Communty used the term "supranational" apparenty for the first time in an intemational legal document. Article $9(5)$ proviles that the members of the High Authority "shall refrain from any action incompatible with the supra-national charater of their functions." TREATY INSTITUTDNG THE EUROPEAN COAL NND STEEL COMMUNITY. Apr 15. 1951, 261 
More precise definitions of supranational organizations emphasize their ability to penetrate the surface of the state. Giuseppe Schiavone, for example, observes: "Supranational organizations have the ability to make decisions which are directly binding upon member states, public and private enterprises, as well as individuals within these states, whereas traditional international organizations can act or execute decisions only by or through member states." Similarly, in listing six "fundamental characteristics" of an idealtypical supranational organization, Henry Schermers and Niels Blokker note that " $[t]$ he organization should be empowered to make rules which directly bind the inhabitants of the member states."

This relationship between supranational institutions and the citizens and subjects of domestic governments represents another departure from the bedrock assumption of traditional public international law: that states, functioning as unitary entities, are the only subjects of international rules and institutions and hence the only recognized actors in the international realm. ${ }^{52}$ Supranationalism, like contemporary human rights law, acknowledges that states are themselves composed of governments interacting with a panoply of nonstate actors: individuals, groups, corporations, and voluntary organizations. ${ }^{53}$ Recognizing rights for these nonstate actors and granting them distinct and independent status before supranational institutions dismantles the fiction of the unitary state.

The move away from the unitary state entails an equally important move away from the fiction of a unitary government. Efforts by supranational institutions to make and enforce rules directly affecting the citizens of domestic governments will overlap and potentially alter the relationship between those citizens and their domestic government institutions: courts, administrative agencies, legislatures, and executives. For instance, private parties are likely to try to enforce rights granted them by a supranational tribunal through

U.N.T.S. 140, 143 (entered into force July 25,1952 ). One scholar has suggested that the term was deviscd to avoid the more controversial term "federal." See SCHERMERS \& BLOKKER, supra note 47, § 61, at 41 (citing H. WAGNER, GRUNDBEGRIFFE DES BESCHLUBRECHTS DER EUROPAISCHEN GEMEINSCHAFTEN 81-82 (1965)). Schermers and Blokker suggest, however, that no true supranational organization exists, at least according to their ideal-typical definition, although they agree that the European Union comes the closest. See id. $\S 62$, at 42 . Additional authorities defining supranational organization with reference to the European Union are collected in John Head, Supranational Law: How the Move Toward Multilateral Solutions Is Changing the Character of "International" Law, 42 KAN. L. REv. 605, 622 n.109 (1994).

50. GIUSEPPE SChIAVONE, INTERNATIONAL ORGaNIZATIONS: A DictionaRY aNd DIRECTORY 3 (3J ed. 1993).

51. SCHERMERS \& BLOKKER, supra note $47, \S 61$, at 41.

52. See IAN Brownlie, Principles of PUblic INTERnational Law 58-59 (4th ed. 1990) ("It is states and organizations (if appropriate conditions exist) which represent the normal types of legal persons on the international plane.").

53. In domestic politics, we would refer to these "nonstate actors" as citizens, both individual and corporate, or groups and organizations of citizens. From the perspective of the international system, however, it is their nonstate status that is noteworthy. 
domestic courts. ${ }^{54}$ In response to this intrusion, domestic government institutions may choose to assert their traditional sovereignty or to forge direct relationships with their supranational counterparts. The result is the "disaggregation" of governments into their component parts or branches"

This web of potential relationships between private paries, supranational entities, and domestic govemment institutions lies at the hear of supranational adjudication. We define supranational adjudication, in its purest form, as adjudication by a tribunal that was established by a group of states or the entire international community and that exercises jurisdiction over cases directly involving private parties-whether between a privale party and a foreign government, a private party and her own government, privale parties themselves, or, in the criminal context, a private party and a prosecutor's office. $^{56}$ Traditional international adjudication, by contrast, involves only state-to-state litigation. ${ }^{57}$ Tribunals engaged in supranational adjudication may also exercise jurisdiction over state-to-state cases, but in their supranational capacity they have the potential to be far more effective than their pure international counterparts.

As a result of their ability to penetrate the surface of the state, supranational tribunals have an additional set of potential mechanisms for compelling litigants to appear and to comply with the resulting judgments. In pure international litigation, in which states are treated as unitary actors, the government of a particular state is represented by the head of state or the foreign office. Other domestic government institutions may be involved in determining the position taken by the head of state or the foreign office, but

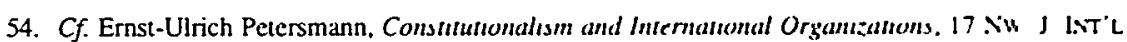
L. \& Bus. 398, 443 (1996-1997). As Petersmann wntes

[A] rights-based approach, enabling self-interested indisiduals to enlorce international guarantees of freedom and non-discrimination through [nstional) courts, has likew ise enabled a dynamic evolution of the European Conventuon on Human Rights The ven smsll number of complaints among member state governments at the EC Court, as well is at the European Court of Human Rights, confirms that indwisdusls mas be the best guardians and Id. promoters of rule-oriented international cooperation

55. For related discussions of the disaggregation of the state, sex Anne-Nlane Slsughter. Internathonal Law in a World of Liberal States. 6 EUR. J INT'L L 503. 522.23 (IW95) [heremalter Slsughter, International Law]; and Anne-Marie Slaughter, The Real New World Order. 76 FenklGX Art 153 11997,

56. For another definition of "elements which give an international court a suprandtionsal charater." see GRIEVEs, supra note 47, at 16-17 Gneves argues that a coun can be satd to hate supranditonal powbers only when it transcends the usual limitations of the protospe international court, that is, that only states are litigants and must consent to litigation He cnumerates sesctal elements that rellect supranatunalism in practice: a court's ability to determine its own junsdiction. the identily of purtes betore the cuun disposition for and against states where individuals hase standing. judicial impanuality, and, signticantly. enforcement of judgments and complance See id HC thus assumes that a suprarstiensl inbunal by definition is more effective than an international one We stek to uncoser the mechanisms by which such effectiveness is achieved.

57. Between these two pure examples are a range of tribunals molore which powste partes do nut hase standing but whose rulings may have a dire:t beanng upon theit prouniar) or polstival interests in the domestic realm, motivating them to monitor and inlluence the process of interstale sdjudic dlun We discuss the applicability of our checklist to these tribunals in the conclusion Ser infra Pan V'I 
the international tribunal has no way to interact directly with those institutions. In pure supranational adjudication, by contrast, the direct link between supranational tribunals and private parties creates opportunities for those tribunals to establish direct or indirect relationships with the different branches of domestic governments. Through these relationships, a supranational tribunal can harness the power of domestic government to enforce its rulings in the same way that the judgments and orders of a domestic court are enforced. ${ }^{58}$

In sum, we measure the effectiveness of a supranational tribunal in terms of its ability to compel compliance with its judgments by convincing domestic government institutions, directly and through pressure from private litigants, to use their power on its behalf. Part III of this Article spells out the various specific ways in which supranational tribunals and the states that establish them can maximize their effectiveness along these dimensions. The resulting "checklist" is based on the experience of two European supranational tribunals: the ECJ and the ECHR. We turn first, however, to the history of these two tribunals, focusing on the role played by private parties in securing compliance with their rulings and highlighting the empirical judgments of scholars and practitioners that the tribunals are regarded as effective much in the way that domestic courts are viewed as effective.

\section{THE STORY OF EUROPE}

The two principal supranational tribunals in Europe, the ECJ and the ECHR, have proved to be remarkably effective. This part traces the history of each in turn and then briefly compares their experiences.

\section{A. The European Court of Justice}

The European Court of Justice was established by the Treaty of Rome as a court of limited international jurisdiction charged with interpreting and applying the treaty in disputes between member states of the European Community or between the Commission of the Community and one or more member states. ${ }^{59}$ At the outset, the ECJ's powers appeared no greater than those of the ICJ; it had jurisdiction over disputes between states, but no direct means of enforcing its decisions. Yet, over a forty-year period, the ECJ succeeded in transforming the Treaty of Rome and secondary Community

58. Schermers and Blokker similarly conclude that "[i]t may well be possible that other organs of the member states are used to aid the [supranational organization]" with regard to enforcing supranational rules. SCHERMERS \& BLOKKER, supra note $47, \S 61$, at 41 . "Thus, a national parliament and the national judiciary may coerce their government to fulfill its obligations to the organization." Id.

59. See TREATY OF ROME art. 169 (permitting the Commission of the Community to refer cases of noncompliance with its opinions to the Coun of Justice); id. an. 170 (permitting member states to bring before the Commission of the Community and the Court of Justice other member states that have allegedly failed to fulfill treaty obligations). 
legislation into law directly enforceable in cases brought by private parties in the domestic courts. European Union law is supreme over domestic law and recognized as such by domestic courts-not, in most cases, by action of domestic constitutions or legislative provisions, but by decree of the ECJ itself. a decree ultimately accepted even by the highest national courts. ${ }^{\circ}$

The task facing the ECJ was the penetration of national legal systems. It accomplished this task by exploiting a relatively obscure provision in the Treaty of Rome, Article 177, which allowed all national courts, and required national courts of last resort, to refer cases involving the application of European law to the ECJ for a preliminary ruling on the European law issues. ${ }^{61}$ The ostensible purpose of this provision was to ensure uniformity of interpretation of the treaty by ensuring that six (now fifteen) sets of national judges did not develop divergent interpretations of the treaty and Community secondary legislation. In one of the earliest referrals, however, the ECJ took matters into its own hands and declared the doctrine of "direct effect," holding that certain provisions of the Treaty of Rome are directly applicable to individuals within national legal systems. ${ }^{62}$ Individuals could thus invoke these provisions in national court against contrary provisions of national law; the national court was then to refer the issue to the ECJ for resolution.

Over the course of several decades, the number of references from national courts to the ECJ steadily increased, effectively providing the ECJ with domestic enforcement mechanisms for its judgments. ${ }^{63}$ The doctrine of direct effect was quickly followed by the doctrine of supremacy of European

60. The classic account of the construction of the European Communuty's legal system is tound in J.H.H. Weiler, The Transformation of Europe, 100 YALE L.J 2403 (1991) Weiler folluw's in the luolsteps of Eric Stein, Lawyers, Judges, and the Making of a Transnathonal Constituhon. 75 AM J INT'L L I (1981), which first alened intemational lawyers to the potential significance of the ECJ's tehtevements For an influential account by a member of the ECJ. see G Fedenco Mancin. The Haking of a Constiufion for Europe, 26 COMMON MKT. L. REV. 595 (1989). Two more general atcounts. the first writuen Irum a legal realist perspective highlighting the motives of ECJ judges in developing a teleological interpretution of the Treaty of Rome and the second seeking to integrate legal accounts with political seitence theory, afe

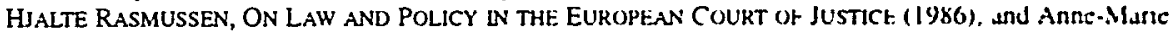
Burley \& Walter Matti, Europe Before the Court: A Political Theon of Legal Integrahion. 47 LVT'L ORO 41 (1993).

61. Article 177 of the Treaty of Rome provides. "The Coun of Jusuce shsll be cumpetent to make 4 preliminary decision concerning... the validity and interpretation of Jits of the instututions of the Community; and . . . the interpretation of the statutes of any bodies set up by an sta of the Council TREATY OF ROME art. 177. Any court of a member state may reler a case involving such issues to the ECJ Further, national courts of last reson, "from whose decisions no appeal lies under municipal law." must refer cases raising questions of European law to the ECJ $/ d$ Article 171 requires member stutes to "uske the measures required for the implementation of the judgment" of the ECJ $I d$ an $17 \mid$

62. See Case 26/62, N.V. Algemene Transp \& Expeditic Onderneming Van Gend \& Luos $v$ Nederlandse administratie der belastingen, 1963 E C.R 1. 12. see also Weller, supra nute 60. At 2\$13-14 (discussing the doctrine of direct effect).

63. A quantitative illustration of the growing importance of Community law is the number of cases referred to the ECJ by domestic courts. The number jumped from a low of nine in 1969 to a high of 119 in 1978; by 1993, domestic court referrals were "in fact the most common kand of wase on the Cuun's docket (about one-half), numbering over 150 per year" Gtokgt A BtkMANi $+\mathrm{T}$ Al. ElkoptAs COMMUNTY LAW 245 (1993); see also Burlcy \& Matul, supra nole 60. 4 it 48 
Community law over conflicting national law, a much more direct enforcement mechanism than the system of national implementing legislation that the treaty's drafters originally envisioned. ${ }^{64}$ Other ECJ innovations included implied powers for Community lawmaking, preemption of conflicting national legislation, and the development of a human rights jurisprudence to check potential excesses of Community law and actors. ${ }^{65}$

Acceptance of these doctrines by national courts has given the judgments of the ECJ in cases referred to it under Article 177 roughly the same effect as judgments issued by domestic courts in the member states of the European Union. ${ }^{66}$ Individuals, corporations, and government agencies anticipate the ECJ's position on important economic and political questions; its decisions are carefully reported and analyzed not only in legal reporters, but also in major national newspapers. ${ }^{67}$ Indeed, the ECJ's success has been such that it has been widely credited with transforming the Treaty of Rome from an international instrument into the "constitution" of the European Community. ${ }^{68}$

The ECJ's effectiveness has traditionally been measured with regard to its adjudication of Article 177 cases. $^{69}$ By contrast, its record in cases brought by states against one another and by the Commission of the Community against member states has been spotty. States have been hesitant to sue one another, preferring to bring their complaints to the Commission. ${ }^{70}$ The

64. See Weiler, supra note 60 , at 2413-19 (discussing the doctrines and citing major authoritics analyzing them).

65. See id.

66. See, e.g., Geoffrey Garrett, International Cooperation and Institutional Choice: The European Community's Internal Market, 46 INT'L ORG. 533, 555 (1992) ('The system [implemented by the ECJ] has been quite effective. There is no systematic difference within countries in the extent to which EC laws are followed relative to purely national laws."); Weiler, supra note 60 , at 2464 (noting that, although noncompliance with ECJ judgments does occur, "[i]n this respect the Community is no different (in principle) than, for example, any state of equivalent size and complexity," and that noncompliance occurs "in a constitutional context with an ethos of domestic rather than international law"); see also Petersmann, supra note 54, at 465 ("The experience of ... EC law . . . clearly suggests that cooperation between international and national courts, and the right of individuals to invoke the international obligations of governments before the national judiciary, are of crucial importance for rendering international law more effective within domestic legal systems.").

67. See, e.g., Deichmann To Go to EU Court over Commission Anti-Dumping Proposals, Frankfurter Allgemeine Zetrung, Oct. 15, 1996, at 29; David Rowan, Gay Rights: Coming Out of the Shadows; A Notable Ruling in Europe in Favour of a Homosexual British Man Heralds the Last Stages in the Long Struggle for Equality, GUARDIAN (London), Oct. 9, 1997, at 17.

68. See Case 294/83, Parti écologiste 'Les Verts' v. Parliament, 1986 E.C.R. 1339, 1365 (describing the Treaty of Rome as "the basic constitutional charter" of the Community); see also Weiler, supra note 60 , at 2413 (referring to the ECJ's efforts as "[c]onstitutionalization' of the Community legal structure"). For a recent comprehensive discussion of the constitutional character of European Union law, sec J.H.H. Weiler \& Ulrich R. Haltern, The Autonomy of the Community Legal Order-Through the Looking Gliss, 37 HARV. INT'L L.J. 411 (1996).

69. See J.H.H. Weiler, The European Court, National Courts and References for Preliminary Rulings-The Paradox of Success: A Revisionist View of Article 177 EEC, in ARTICLE 177 EEC: EXPERIENCES AND PROBLEMS 366, 366-67 (Henry G. Schermers et al. eds., 1987).

70. See Alan Dashwood \& Robin White, Enforcement Actions Under Articles 169 and 170 EEC, 14 EUR. L. REV. 388, 409 (1989) ("In practice the Member States have shown little enthusiasm for their independent right of action under Article $170 \ldots$ The preferred approach . . . seems to be to complain to the Commission and leave it to that body to take action."); see also KAREN ALTER, THE EUROPEAN COURT 
Commission, in turn, was also initially reluctant to sue member states because of its need to establish its own political legitimacy." Further, even in those cases brought to the ECJ, compliance with resulting judgments has been mixed. ${ }^{72}$ Strikingly, the ECJ solved these enforcement problems by turning again to private parties and domestic courts, holding in Francovich v: Ital ${ }^{73}$ that a state that failed to implement a Community directive could be required to pay compensation to iniured private parties.

\section{B. The European Court of Human Rights}

Beginning from a similarly modest position, the ECHR has succeeded in transforming a relatively empty docket into a relatively teeming one. It has declared its principal text, the European Convention for the Protection of Human Rights and Fundamental Freedoms, ${ }^{74}$ a "constitutional instrument of European public order," $" 75$ just as the ECJ gave the Treaty of Rome constitutional status within the European Community. In addition, the ECHR has successfully established itself as the final interpreter of the Convention's provisions. ${ }^{76}$ And it has witnessed its rulings change the shape of domestic law, through both legislative revision and judicial decision. ${ }^{7}$

AND National COURTS DOCTRINE AND JURISPRUUENCE. LFGal CHANGE IN ITS SUCIAL CUNTEXT [EXPLAINING National COURT ACCEPTANCE OF EUROPEAN COURT JURISPRUDENCT $A$ CRITICAL EVALUATION OF ThEORIES OF LEgal INTEgRation] 33 n 17 (European Univ Insi. Florence. Working Paper RSC No. 95/27, 1995) ("In the history of the Communty. Member States have only raised 3 cases against another member state.").

71. See ALTER, supra note 70, at 34 ("The Commission's reluctance to pursue breathes was most likely based on political concerns."); Stein, supra note 60. at 6 ("IU/nul quite recently. the Commission obviously hesitated to aggravate its fragile relationships with member governments by bnnging them into Court-and a decision by a member government to sue another posed politucal difficulies of a similar nature.").

72. See Weiler, supra note 60 , at $2464-65 \&$ nn $177-78$ (noung the increasing lack of complance by states in cases brought by the Commission of the Communtly or another member state) But see Dashwood \& White, supra note 70, at 411 (concluding that member stales have "almost always taken the steps necessary to comply with [Article 169 judgments], although sometumes after considerable delay")

73. Cases C-6/90 \& C-9/90. Francovich v. Italy. 67 C M.LR 66 (1991). see also J Duthetl de la Rochere, Member State Liability for Infringement of European Communtr Lam. II TUL EUR \& CW LF 1, 3-5 (1996) (analyzing Francovich and its progeny).

74. Convention, supra note 2.

75. Loizidou v. Turkey, 310 Eur. Ct. H.R. (ser A) at 27 (1995), see also RaLPH BtDDARD. HUMAN RIGHTS AND EUROPE 5-6 (3d ed, 1993) (characterizing the Convention als a kind of constututional document for a united Europe").

76. See, e.g., Barfod v. Denmark, 149 Eur. Cl H.R. (ser A) at 12 (1989) (clatmung that the ECHR is "empowered to give [a] final ruling" on whether a state's intefference with a protected nghi is compatible with the Convention); Muller v. Switzerland, 133 Eur Cl HR (ser A) at 21 (1988) (same). Lingens v. Austria, 103 Eur. Cl. H.R. (ser. A) at 25 (1986) (same)

77. See J.G. MERRILLS, THE DEVELOPMENT OF INTERNATIONAL LAW BY THE EUROPtAN COUKT UF HUMAN RIGHTS 12 (2d ed. 1993) ("The most dramatic impact of the Court's work is centunly to be found in the changes in domestic law and practice which have been introduced as a result of cases at Strasbourg ... .); Richard S. Kay, The European Convention on Human Rights and the Authorin of Law, 8 Cown J. INT'L L. 217, 218 (1993) (observing that the European Convention is "accepladed] as a genutne system of law" and that judgments of the ECHR are "routunely[l] honored by the respondent states who both pay the compensation ordered by the Coun and also adjust their laws and governmental practuces to the Coun's interpretations"). 
The Convention arose out of a broader effort to promote social and economic progress among European states after World War II. It codifies a basic catalog of civil and political liberties and confirms the desire of its signatories to achieve "a common understanding and observance" of those rights. ${ }^{78}$ Although originally ratified by few countries outside of Western Europe, as of 1997 forty nations from Iceland to Russia have signed on to the treaty and one or more of its various protocols. ${ }^{79}$

In addition to setting forth substantive guarantees, the Convention creates an intricate enforcement mechanism to permit individuals and groups to file complaints against their national governments alleging violations of European human rights norms. Although the treaty does not compel states parties to recognize this right of petition or the compulsory jurisdiction of the ECHR, in practice all of the treaty's signatories have filed permanent or renewable declarations accepting both obligations. ${ }^{80}$ Commentators have stressed the importance of this individual access right as crucial to the success of the Convention in altering the domestic legal landscape. ${ }^{81}$

Individuals who allege that their human rights have been violated first present their claims to the European Commission of Human Rights (the Commission), a quasi-judicial tribunal which screens the claims for possible violations of the Convention. ${ }^{82}$ The Commission dismisses the majority of claims for failing to satisfy the Convention's admissibility criteria ${ }^{83}$ or for being without merit ("manifestly ill-founded" in the parlance of the Convention $^{84}$ ). For those cases in which a violation of the Convention is clearly apparent or that present unresolved questions of interpretation, the Commission declares the complaint admissible and receives additional evidence and arguments from the parties. If no amicable resolution can be negotiated, the Commission issues a decision explaining whether the state party has breached its obligations under the Convention. ${ }^{85}$

78. Convention, supra note 2, pmbl., 213 U.N.T.S. at 222.

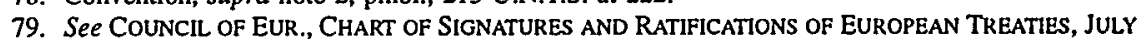
1, 1996 UPDATE [hereinafter CHART OF SIGNATURES 1996].

80. See Council of Eur., DeClarations Pursuant to ARTICles 25 and 46 of the Convention For the PROTECTION OF HUMAN RIGHTS AND FundaMENTAL FREEDOMS, JULY 1, 1997 UPdATE.

81. See, e.g., BEDDARD, supra note 75, at 1; A.H. ROBERTSON \& J.G. MERRILLS, HUMAN RIGHTS IN EUROPE 258-59, 284 (3d ed. 1993); P. VAN DUK \& G.J.H. VAN HOOF, THEORY AND PRACTICE OF THE EUROPEAN CONVENTION ON HUMAN RIGHTS 34-35 (1984).

82. The Commission has decided thousands of cases concerning virtually all of the substantive rights guaranteed by the European Convention. Because cases dismissed at a preliminary stage may not be appealed to the ECHR by the aggrieved individual, only a few hundred of these cases have actually reached the court. See Henry G. Schermers, The European Court of Human Rights After the Merger, 18 EuR. L. REV. 493, 495 (1993).

83. Before filing a petition, an individual must exhaust all available and effective national remedies and must file his or her complaint with the Commission within six months of any "final decision" by a national authority. See Convention, supra note 2, art. 26, 213 U.N.T.S. at 238.

84. Id. an. 27,213 U.N.T.S. at 238.

85. See id. art. 31,213 U.N.T.S. at 240. 
At this point, either the Commission or the defending state (or states) may appeal the decision directly to the ECHR. Under the Convention itself, individuals have no right of appeal. ${ }^{86}$ Once seized of an appeal, the court reviews the evidence and legal argument de novo and renders a final judgment. ${ }^{87}$ If neither the Commission nor the state appeals the decision, the case is referred to the Committee of Ministers, the executive arm of the Council of Europe, which is composed of the ministers of foreign affairs or their designees from each of the member states of the Council. The Committee, which is also charged with ensuring compliance with the judgments of the court, then renders a final decision on the case. ${ }^{88}$

Although all of the treaty parties "undertake to abide by the decision of the Court in any case to which they are parties," the court's judgments varies considerably. Approximately half of the signatories to the Convention have incorporated the treaty into domestic law, thereby allowing individuals to invoke the treaty and the ECHR's judgments in national judicial proceedings. ${ }^{90}$ The remaining states fulfill their Convention obligations by giving effect to specific judgments of the ECHR, in nearly all cases agreeing to introduce legislative amendments, reopen judicial proceedings, grant administrative remedies, and pay monetary damages to individuals whose treaty rights have been violated. ${ }^{91}$

86. See RALPH BEDDARD, HuMan RIGHTS AND Europe 43 (2d ed 1980) In 1990, however, several states ratified an optional protocol to the treaty that permits individuals and groups to appeal a decision of the Commission to a three-judge panel of the court. The panel has the authonty to dispuse of the case af it "does not raise a serious question affecting the interpretation or appltcation of the Convention and dues not for any other reason warrant consideration by the Coun." Protocol No 9 to the Convention for the Protection of Human Rights and Fundamental Freodoms, opened for signature Nov 6. 1990, an 5. para. 2, Europ. T.S. No. 140 (entered into force for 23 states June 10. 1996) (1971).

87. See DeWilde, Ooms \& Versyp Cases (The Vagrancy Cases), 12 Eur CI H R (ser A) al 29

88. See Convention, supra note 2, ar. 32, 213 U.N.T.S at 240-42

89. Id. an. 59, 213 U.N.T.S. at 250.

90. See ANDREW DRZEMCZEWSKI, THE EUROPEAN HUMAN RIGHTS CONVENTION LN DUMESTIC LAW 260-303 (1983).

91. The European Convention's influence on domestuc legal systems is addressed in a growing literature. For a succinct discussion of the scope of the Strasbourg organ's influence on domestic courts. see Andrew Drzemczewski \& Jens Meyer-Ladewig, Principal Characierishcs of the New ECHR Confrol Mechanism, as Established by Protocol No. IJ. Signed on II May. 1994. 15 HUM RTS L. J 81. 82 (1994). which documents changes in Ausurian, Belgian, Dutch, and lnsh law as a result of ECHR decisions Other sources provide in depth, country-by-country discussions of the ECHR's far-reaching effects on legislatuve reform, case law, and revision procedures. See Jorg Polakiewicz \& Valéne Jacob-Foltzer. The European Human Rights Convention in Domestic Law: The Impact of the Strasbourg Case-Law in States Where Direct Effect Is Given to the Convention (pts. I \& 2), 12 HUM RTS L.J. 65. 67-68. 125, 137 (1991) (detailing 30 years of the ECHR's influence on legislatuve reform and case law in the states pary to the Convention, including the reopening and modification of purponedly final judicial decisions) For studies of the effect of the Strasbourg case law on domestuc legislation in the countres of Eastem and Central Europe, see Michael O'Boyle, Right To Speak and Associale Under Sirasbourg Case-Law with Reference to Eastem and Central Europe, 8 CONN. J. INT'L L. 263 (1993); and Jorg G Polakiewicz. The Domestic Implementation of the European Convention on Hunan Rights in Eastem and Westem Europe. 2 ALL.EUR HuM. RTS. Y.B. 11 (1992). 
In response to the widespread success of the individual petition mechanism in Europe, the growth in the number of states party to the Convention, and an increasing backlog of cases, ${ }^{92}$ the Council of Europe has sought to improve upon the existing judicial review machinery. In May 1994, after years of study and months of arduous negotiations, a majority of states parties signed Protocol No. 11 to the Convention. ${ }^{93}$ The Protocol, once ratified by all of the states, ${ }^{94}$ will revolutionize the treaty's enforcement machinery, abolishing the European Commission of Human Rights and creating a permanent European Court of Human Rights. ${ }^{95}$ Under the new regime, all states parties must recognize the compulsory jurisdiction of the permanent court and permit individuals direct access to it in all cases.

The rate of compliance by states with the ECHR's rulings is extremely high. Indeed, its judgments have been described as being "as effective as those of any domestic court." ${ }^{96}$ As with the ECJ, however, this record of success has occurred principally in cases brought by individuals against their national governments. By contrast, the effectiveness of the handful of interstate complaints $^{97}$ filed with the European Commission and the ECHR is doubtful,

92. Cases decided in 1992 took an average of five years and six months to be resolved-four years and four months before the Commission and 13 months before the Court. See Andrew Drzemczewski, Putting the European House in Order, 144 NEw L.J., 645, 646 (1994).

93. Protocol No. 11 to the Convention for the Protection of Human Rights and Fundamental Freedoms, opened for signature May 11, 1994, Europ. T.S. No. 155 [hereinafter Protocol No. 11].

94. As of May 1997, all 40 contracting states had signed Protocol No. 11, but seven had yet to ratify it. See Council of Europe Chart of Signatures and Ratifications: Protocol No. 11 to the

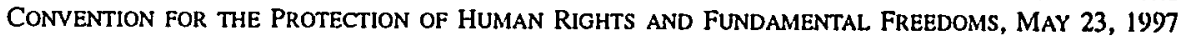
UPDATE. The ratification process has been described as "extremely slow" and has been encumbered by foot dragging by states such as Turkey. Patrick Smyth, European Court Vacancy Arises in Early 1998, IRISH TIMES, Mar. 14, 1997, at 5. Nevertheless, complete ratification is anticipated in 1998 or 1999. See id.

95. The court will screen cases in committees of three judges, with admissible cases being considered by a chamber of seven judges. In exceptional cases, such as "to ensure the quality and consistency of the Court's case law," an appeal may be referred to a grand chamber of 17 judges. Drzemczewski, supra note 92, at 644.

96. CARTER \& TRIMBLE, supra note 36, at 309; see also R. Ryssdal, The Enforcemem System Set Up Under the European Convention on Human Rights, in COMPLIANCE WITH JUDGMENTS OP INTERNATIONAL CourTs 49, 67 (M.K. Bulterman \& M. Kuijer eds., 1996) (analyzing the effectiveness of ECHR judgments as measured by compliance with judgments and quoting the President of the ECHR as stating that "to date judgments of the [ECHR] have ... not only generally but always been complied with by the Contracting States concerned," although noting some delays in compliance); Colin Warbrick, Expansion of Rightss Protection by the European Convention on Human Rights, in CONTROL OVER COMPLIANCE WITH INTERNATIONAL LAW 139, 140 (W.E. Butler ed., 1991) [hereinafter CONTROL OVER COMPLIANCE] ("With no exceptions, the judgments of the [ECHR] have been complied with by the States without the need for "enforcement."').

One significant exception to this trend, however, occurred when the United Kingdom formally derogated from the ECHR's ruling in Brogan v. United Kingdom, 145-B Eur. Cl. H.R. (ser. A) at 30 (1988), in which the coun held that prolonged pretrial detention of suspected terrorists in Northern Ireland violated the Convention. See Brannigan v. United Kingdom, 258 Eur. Ct. H.R. (ser. A) at 56 (1993) (upholding the government's actions under the Convention's derogation clause). Nevertheless, with this sole exception, the British government has formally taken the position that "Britain complies meticulously with every adverse decision of the Court once it has been made." A.W. Bradley, The United Kingdom, the European Court of Human Rights, and Constitutional Review, 17 CARDOZO L. REv. 233, 250 (1995).

97. See Scott Leckie, The Inter-State Complaint Procedure in International Human Rights Law: Hopeful Prospects or Wishful Thinking?, 10 HUM. RTS. Q. 249, 255 (1988) (noting that there have been 
again demonstrating the crucial role played by private parties in securing compliance with supranational court rulings. ${ }^{98}$

\section{The European Courts Compared}

The trajectories of the ECJ and the ECHR reflect important differences. The ECJ interacts with national courts in a kind of partnership based on distinct but complementary spheres of jurisdiction; the ECHR is more likely to be in the position of reviewing the handiwork of national courts in a more traditional hierarchical relationship. Further, the ECJ superintends a treaty that has the stated objective of creating "an ever closer Union" of fifteen European nations; ${ }^{99}$ the ECHR oversees compliance with a specific catalog of human rights obligations in forty countries. The $\mathrm{ECJ}$ is thus a tribunal of much wider substantive jurisdiction, addressing economic issues with an explicit political dimension. In comparison, the ECHR has a narrower and more traditional judicial role. On the structural side, the ECHR does not have an Article 177 mechanism allowing it to communicate directly with national courts. The ECHR thus faces a different task of convincing national legislatures, at least in the first instance, to conform to its judgments.

Notwithstanding these differences, it is possible to identify many similarities in the structure and practice of the ECJ and the ECHR that transcend the differences between them. They are both supranational courts with no direct means of enforcing their judgments and thus are apparently dependent on the goodwill of national governmental institutions. Within these constraints, they have built a remarkable record, becoming important actors on the domestic as well as the international legal scene. Moreover, their experience confirms the theoretical analysis of effective supranational adjudication set forth in Part I. Each court achieved substantial compliance with its judgments by forging relationships with domestic government

only 18 interstate complaints concerning "six distunct human nghts volatuons")

98. As van Dijk and van Hoof point out:

[I]t is evident that the right of complaint of States has proved not to be very effective (T/he contracting States have not been willing to expose situations in other States if no interest of their own is involved. Such a step generally runs counier to their own inierest in that a charge of violation of the Convention will be considered an unfnendly act by the other pany. with all the political consequences that may be involved.

VAN DUK \& VAN HOOF, supra note 81, al 33; see also BEDDARD, supra nole 75. at 9 (churactenung interstate petitions as "unsatisfactory" and based on "unfnendliness in the relations between states"). ROBERTSON \& MERRILLS, supra note 81 , at 284 (criticizing the setuement of an inierstate complaint against Turkey as a political compromise that failed to protect adequatcly individual nghts and stating that " $|1| \mathrm{n}$ a comparable case brought by an individual 11 is inconceivable that an arrangement so patcnily unsatisfactory would have been approved"); id. at 284-85 (arguing that "politueal considerations are likely to influence the way the Convention works in inter-state cases to a much greater extent than in cases brought by individuals").

99. TREATY OF ROME pmbl. 
institutions, both directly and indirectly through relationships with private parties.

Further, the collective European experience of supranational adjudication is greater than the sum of its parts. The ECJ and the ECHR have become part of a larger European "community of law": a network of legal actors self-consciously interacting with one another on the basis of both self-interest and shared values in a nominally apolitical context. The existence of a community of law as a precondition for a well-functioning legal system within a state is taken for granted; the expansion of such a community beyond the boundaries of any one state, however, is a remarkable phenomenon. A community of law is both a cause and a consequence of effective supranational adjudication. We return to the relationship between these two phenomena, in both the European and the global context, in Part V. First, however, we turn to a more specific analysis of the factors contributing to effective supranational adjudication.

\section{A CHECKLIST FOR EFFECTIVE SUPRANATIONAL AdJUdICATION}

The purpose of generating a "checklist" for effective supranational adjudication is to develop a tool that can be used to assess the effectiveness of other supranational tribunals and to guide the members of those tribunals in seeking to enhance their own effectiveness. We thus divide the checklist into several categories of factors that plausibly affect the effectiveness of supranational tribunals. First are those factors within the power of the states responsible for establishing a supranational tribunal and dictating its relationship to domestic tribunals. Second are those factors within the power of the supranational tribunal itself. Third are more general factors relating to the types of cases presented to a supranational tribunal and to the domestic political configuration and ideology of the states subject to its jurisdiction. Factors in the third category are not fully within the control of states or judges but do not vitiate the importance of factors in the first two categories.

\section{A. A Methodological Note}

We have developed the following compilation of the attributes of effective supranational adjudication by distilling commentary and analysis by judges, lawyers, and political scientists who have closely observed the workings of the ECJ and the ECHR, supplementing these findings with our own analysis. The checklist is intended as a first step toward the development of a more rigorous model of supranational adjudication, one that will ultimately be informed by data from a wider range of tribunals and dispute resolution bodies, such as panels convened under the North American Free Trade Agreement (NAFTA), the Canadian-United States Free Trade Agreement, the Inter-American Court 
of Human Rights, United Nations treaty bodies authorized to receive complaints from individuals, and the War Crimes Tribunals for Rwanda and the former Yugoslavia. From a political science perspective, we have "selected on the dependent variable." tribunals rather than correlating explanatory factors with a range of effective and less effective tribunals.

In compiling this list, we have been guided by three principal considerations. First, we have been as detailed as possible. For instance, many accounts of supranational tribunals attribute their success to attributes like "legitimacy" and "authority." We have sought to break down these umbrella terms into more specific components. Second, we have included the widest possible range of factors: legal, political, social, and cultural. It is quite likely that some factors are partially or even wholly derivative of others. At this stage of the analysis, we value comprehensiveness over parsimony, although we recognize that some classes of factors may prove to be more potent explanatory variables than others.

Third, we have tried to compensate for our inclusionary bias by listing the factors in each category in descending order of importance. Our judgments here are based on both our sense of the literature and our own analysis, although these are precisely the types of determinations that are likely to change in light of additional data from other tribunals. In assigning even a preliminary weight to each factor, we have taken into account the degree of consensus among observers regarding the impact of the particular factor on either the ECJ or the ECHR independently, as well as across both tribunals. It follows that factors listed toward the bottom of each category in the checklist are more context-specific and likely to vary across different tribunals. ${ }^{101} \mathrm{~A}$ related problem is the possibility that some factors are, in fact, counterproductive, though this possibility is outweighed by the simultaneous presence of other more powerful factors. It is again difficult to isolate the impact of specific factors with such a limited initial data set; where possible, however, we have sought not only to list the factors identified by judicial observers, but also to trace the mechanisms by which they exercise their purported impact.

100. Gary King et al., Designing Social Inquiky Scientific lNFekence in Qualtattve RESEARCH 129-32 (1994).

101. In some cases, for instance, a factor and ats opposite may be equally cited as contributung to the effectiveness of the two different courts under consideration In such cases. We are not inclined to rank the factor highly in terms of relatuve imporance; nevertheless, we seek to dnalyze the carcumstances in which one alternative is likely to work better than the other 


\section{B. The Checklist}

\section{Factors Within the Control of States Party to an Agreement Establishing a Supranational Tribunal}

\section{a. Composition of the Tribunal}

If states party to a treaty establishing a supranational tribunal hope to enhance its legitimacy and authority, the experience of the ECJ and ECHR suggests that they should give careful consideration to the background and experience of jurists who serve on it. ${ }^{102}$ Seeking to explain the legitimacy of the constitutional interpretations given to the Treaty of Rome by the ECJ, for example, Joseph Weiler observes that the Court is composed of "senior jurists from all member states [of the European Union]."103 The implicit point is that where a supranational tribunal depends on acceptance of its judgments by national tribunals, it will wield greater authority if its members are known and respected by national judges. ${ }^{104}$

A further implication, however, may be that special expertise in the field of law to be applied by the supranational tribunal is not necessarily the most important qualification for potential tribunal members, at least at the outset of the tribunal's life. For instance, to the extent that international and domestic law are perceived as quite distinct and mutually insulated fields in a particular country, staffing an international tribunal solely with experts in international law may have the paradoxical effect of ensuring that the tribunal's members are less well-known to national judges than appointees of equal distinction who have made a career in domestic law. ${ }^{105}$ The point may carry beyond the need

102. Both the Treaty of Rome and the European Convention on Human Rights provide that their judges must be respected jurists or jurisconsults of high achievement and character. Both specify that judicial appointments are for a fixed term of years and that judges may be reappointed after serving their initial terms. See TREATY OF ROME art. 167 (requiting that judges, who serve for a renewable term of six years, be "persons whose independence is beyond doubt and who possess the qualifications required for appointment to the highest judicial offices in their respective countries or who are jurisconsults of recognised competence"); Convention, supra note 2, arts. 39(3), 40(1), 213 U.N.T.S. at 244 (requiring that judges, who serve for a renewable term of nine years, be of "high moral character" and "either possess the qualifications required for appointment to high judicial office or be jurisconsults of recognized competence").

103. J.H.H. Weiler, A Quiet Revolution: The European Court of Justice and Its Interlocutors, 26 COMP. POL. STUD. 510, 521 (1994).

104. Consider, for example, the increased domestic attention that might be paid to World Trade Organization (WTO) or NAFTA panel rulings if one of the panel members were a widely respected retired Justice of the U.S. Supreme Court.

105. It is perhaps not insignificant in this regard that Robert Lecourt, the enormously influential first President of the European Court of Justice, was a former French Minister of Justice. See RASMUSSEN, supra note 60, at 230. Rudolf Bemhardt, a judge on the ECHR since 1981 and Vice President since 1992. implicitly confirms the importance of judges' substantive areas of expertise when he notes that the ECHR is staffed by "judges of high national courts, professors of law and holders of various other positions in their home country (advocates, government officials, etc.)" and that only "a limited number of the members of the Court has special experience in the area of international law." Rudolf Bernhardt, Human Rights and 
to gain acceptance of particular decisions from national judges, extending also to a greater impact on national administrators and even legislators.

On the other hand, special expertise undoubtedly carries its own authority. One English lawyer, commenting on the willingness of English courts to accept ECJ judgments, emphasizes the recognized expertise of the ECJ in European Union law, an area that can often be arcane to even an experienced and highly competent national judge. ${ }^{100}$ Moreover, it cannot be questioned that expertise in human rights law enhances the prestige of international human rights tribunals. The development of a particular area of law often coincides with the growth and strength of a tribunal charged with interpreting and applying it. National judges in the European Community for instance, would have been unlikely to perceive the value of special expertise in European Community law if the ECJ and its many helpers had not succeeded in making that law a formidable force. If so, the question remains how best to compose a fledgling supranational tribunal so that it is poised to secure the authority and enhance the scope of the body of law it oversees. The ideal may be a mix of international experts and distinguished national practitioners-who themselves may be drawn from the judiciary, the govemment, or the private bar. ${ }^{107}$

\section{b. Caseload or Functional Capacity of the Court}

A second category of factors relevant to the effectiveness of a supranational tribunal that is, at least initially, within the control of member states concerns the caseload and functional capacity of the cour. A cour that is scarcely used, for whatever reason, cannot hope to make much of a mark. ${ }^{108}$ Similarly, a court that is perceived as effective will attract more claimants. The trick is to build a sufficiently high-profile caseload at the outset to attract a steady stream of claimants. The material and financial resources that states devote to the tribunal, together with the degree of complexity they impose regarding its procedures and operations, can assist or hamper this endeavor.

Attracting cases was the prime concern for ECJ judges in the early years of the Court. To build their docket, they had to attract references from national

Judicial Review: The European Court of Human Rights, in HUMAN RIGHTS AND JUDICLAL REVIEW A Comparative PERSPECTIVE 297, 301-02 (David M. Beatly co. 1994) For a general discussion of the professional background of both judges and advocates general, see L. NEvILLE Brown \& TON KENEDY. THE COURT OF JUSTICE OF THE EUROPEAN COMMUNITIES 55-59.67-69 (4th ed 1994)

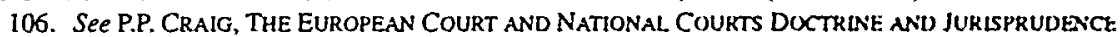
LEGal ChaNGE IN ITS SOCIAL CONTEXT [REPORT ON THE UNTED KingdOM] 26 (European UnIY Inst . Florence, Working Paper RSC No. 95/29, 1995) (noting the increased willingness of judges to refer cases to the ECJ as they become more familiar with the European Union's legal system and recognize the expertise of the ECJ in dealing with Union legal problems).

107. The particular mix should also take into consideration the range of subject matters likeiy to anse on a particular court's docket.

108. See MERRILLS, supra note 77, al 16 
courts under Article 177. As Judge G. Federico Mancini recounts, the "Court's first preoccupation" was to win the "co-operation and goodwill of the state courts." 109 To this end, the Court engaged in an extensive education campaign aimed at national judges, including seminars, dinners, regular invitations to Luxembourg, and visits around the Community. ${ }^{110}$ As will be discussed further below, ${ }^{11}$ the formulation of this strategy was within the control of the ECJ itself, but the judges were substantially aided by factors such as a large budget, a permanent and attractive home with a large library and research staff, and substantial educational and public relations resources. ${ }^{\text {II }}$ The growth of the Court's reputation among litigants over time depended in part on the ready availability of its decisions in multiple languages and the efforts of its research staff in making information available to lawyers, litigants, and scholars on demand. ${ }^{113}$

The ECHR faced a similar task and was similarly aided. The court's docket swelled from a relative trickle of cases in the 1950s and 1960s to a flood in the 1980s. ${ }^{114}$ Many factors contributed to this increase, including the rapid growth of the members of the Council of Europe and the resulting increased number of potential plaintiffs. ${ }^{115}$ Nevertheless, the ECHR's relatively comfortable working conditions (which make it easier to attract distinguished judges), its physical location in Strasbourg, its relatively ample budget, and its ability to publicize its decisions have all contributed to its visibility and success. ${ }^{116}$

States responsible for establishing international tribunals can thus help ensure that the tribunals will have a sufficient caseload to be effective by

109. Mancini, supra note 60 , at 605 .

110. See RASMUSSEN, supra note 60 , at 247.

111. See infra Subsection III.B.2.a.

112. See BROWN \& KENNEDY, supra note 105 , at $15-42$.

113. See id. Brown and Kennedy describe in detail the resources made available to the Court, including interpreters, information officers, extensive library and documentation services, as well as an impressive coun building.

114. Although the Commission has "continuously tried to increase its productivity," Schermers, supra note 82 , at 497 , it has been unable to keep up with the rise in complaints. In 1985, the number of applications rose to 600 , in 1987 to 863, in 1989 to over 1300, and in 1992 to 1862. More than 2500 cases were pending before the Commission as of December 1995. See id. at 495 . Only a fraction of these cases actually reached the coun, of course; nevertheless, the pattern of expansion is evident.

115. See Henry G. Schermers, The Eleventh Protocol to the European Convention on Human Rights, 19 EUR. L. REV. 367, 368 (1994) (noting an increase in cases due to the court's acceptance by all participating states and the need to render judgment in all important cases); Karel de Vey Mestdagh, Reform of the European Convention on Human Rights in a Changing Europe, in THE DYNAMICS OP THB PROTECTION OF HUMAN RIGHTS IN EUROPE 337, 339-40 (Rick Lawson \& Matthijs de Blois eds., 1994) (discussing the unexpected burden placed on the ECHR by the increase in member states and the unforeseen number of serious individual petitions).

116. See Marcus Binney, Where Justice Can Be Seen To Be Done, Tomes (London), Junc 27, 1995, available in 1995 WL 7678063; Denis Rousseau, European Rights Court, Commission Get New Headquarters, AGENCE FRANCE-PRESSE, June 29, 1995, available in 1995 WL 7822707; cf. Lynda E. Frost, The Evolution of the Inter-American Court of Human Rights: Reflections of Present and Former Judges, 14 HUM. RTS. Q. 171, 177-80 (1992) (arguing that the Inter-American Court of Human Rights's slim docket is linked to an inadequacy of judicial resources). 
providing requisite resources. These resources can help to: (1) ensure that judges on the tribunal can educate potential constituencies of litigants concerning both the existence of the tribunal and the law it is charged to apply; (2) dispatch quickly and efficiently the complaints that the tribunal receives; and (3) publicize the results. At the most basic level, this is a matter of money and staffing. But beyond the commitment of material resources, states should give careful attention to the ease and efficiency of the procedures that litigants must follow to bring a case and that judges must follow to hear $\mathrm{tt}$. Cumbersome procedures can block the development of a docket in the first instance and prevent its ready dispatch once cases begin to arrive. That the states party to the European Convention on Human Rights were attuned to these concerns is demonstrated by their willingness to streamline the Convention's judicial review machinery to address a growing backlog of cases. ${ }^{117}$

\section{c. Independent Factfinding Capacity'}

States contemplating the establishment of a supranational tribunal also have the authority to control the specific powers of the tribunal in carrying out its adjudicative function. An important dimension of these powers is the ability to elicit credible factual information on which to base the tribunal's decisions. A guaranteed capacity to generate facts that have been independently evaluated, either through a third-party factfinding process or through the public contestation inherent in the adversary system, helps counter the perception of self-serving or "political" judgments.

Several analysts of the ECHR have emphasized the imporance of the Commission's, and hence ultimately the court's, ability to test independently the truth of the allegations of the parties. ${ }^{118}$ Once the Commission determines that a case is admissible, it is bound by Article 28 of the Convention to examine the application "with a view to ascertaining the facts." 119 Under the established procedure, the state in question is legally bound to cooperate with such an investigation once the Commission has determined, on the basis of an

117. See Schermers, supra note 115 , at 368-69.

118. See, e.g., ROBERTSON \& MERRILLS, supra note 81 , at 11 According to Robertson and Mernlls. the Commission's investigation is "carried out together with the representatuves of the partes, which means in practice a hearing of a judicial nature with the individual applicant and the respondent government represented by counsel on a footing of complete equalily." Id For particular examples of the Commission's effective factinding procedure, see id. at 274-81, which discusses with respect to a senes of prominent cases the importance of the Commission's ability to establish cructal clements of fact through tnvesugation See also Kersten Rogge, Fact-Finding. in THE EUROPEAN SYSTEM FOH THE PROTECTION OF HUMAN RiGHTS 677 (R. St. J. Macdonald el al. eds., 1993) (discussing the Commission's competence to venfy relevant facts, procedural issues related to on-site investigations, and standards of evidence)

119. Convention, supra note 2, an. 28(a), 213 U.N T.S. at 238 (declanng that the Commission "shall, with a view to ascertaining the facts undertake logether with the representatuves of the partues an examination of the petition and, if need be, an investrgation") 
adversary hearing in which both parties are represented, that one is required. ${ }^{120}$ On appeal, the ECHR's analysis of the dispute is aided by the Commission's findings of fact, but the court is also empowered to review those findings de novo. ${ }^{121}$ Thus the legitimacy of both the ECHR's judgments and the decisions of the Commission depend in large part on their ability to generate an accurate factual record.

When sitting as appellate tribunals charged only with answering specific questions of law, courts like the ECJ do not have such factfinding capacity. ${ }^{122}$ The ECJ, however, sits atop a system of courts and tribunals that do have such capacity. Further, the ECJ has the authority to compel the parties to produce documents and "to supply all information which the Court considers desirable," to examine witnesses and the parties themselves, and to seek expert opinions from third parties. ${ }^{123}$

\section{d. Formal Authority or Status as Law of the Instrument That the Tribunal Is Charged with Interpreting and Applying}

Also relevant to effectiveness is whether the instrument that the tribunal is charged with interpreting and the tribunal's decisions themselves are regarded as binding and hence accorded formal status as law. ${ }^{124}$ Both the Treaty of Rome and the European Convention on Human Rights provide that the decisions of the ECJ and the ECHR shall be binding on member states brought before it. ${ }^{125}$ These provisions establish the authority of these bodies

120. Article 28 also obligates the state or states concerned to "furnish all necessary facilities, after an exchange of views with the Commission." Id.

121. See DeWilde, Ooms \& Versyp Cases (The Vagrancy Cases), 12 Eur. Ct. H.R. (scr. A) at 29 (1971).

122. Independent factfinding capacity of an inquisitorial nature is one way of assuring accuracy, but such a system arguably works best when complemented by a modicum of adversary process. In the United States, adversary process rests on the assumption "that truth is likely to emerge more from bilateral investigation and presentation, motivated by the strong pull of self-interest, than from judicial investigation motivated only by official duty." Fleming JAMES, JR. ET AL., CrviL PROCEDURE 5 (4th ed. 1992). The element of personal representation in adversary process also serves values of individual dignity and autonomy, as discussed below. See infra note 212 and accompanying text. Most civil law systems incorporate some element of the adversary process in addition to enhanced "inquisitorial" powers for the judge; while the judge has dominant authority to determine the legal theory to be applied, he or she is highly dependent on the parties for presentation of the evidence. See GeoffreY C. HAZARD, JR. \& Michele Taruffo, American Civil Procedure: AN INTROduction 86 (1993).

123. Protocol on the Statute of the Court of Justice of the European Communities, Apr. 17, 1957, art. 21, 298 U.N.T.S. 147, 152; id. art. 22, 298 U.N.T.S. at 152; id. ant. 25, 298 U.N.T.S. at 153; id. art. 29, 298 U.N.T.S. at 154.

124. We do not use the term "binding" here in the Anglo-Saxon sense of binding precedent, to be followed by all subsequent courts in subsequent cases, but rather in the more general sense as requiring compliance by virtue of a formal treaty provision.

125. See TREATY OF ROME an. 171 ("If the Court of Justice finds that a Member State has fatled to fulfil an obligation under this Treaty, the State shall be required to take the necessary measures required to comply with the judgment of the Court of Justice."); id. art. 176 (mandating that "the Institution whosc act has been declared void or whose failure to act has been declared contrary to this Treaty shall be required to take the necessary measures to comply with the judgment of the Court of Justice"); Convention, supra note 2, art. 53, 213 U.N.T.S. at 248 (requiring the parties to "undertake to abide by the decision of 
as legal tribunals, a factor to which commentators assessing their effectiveness give considerable weight. ${ }^{126}$

"Legal" status, however, operates on several levels. These treaties establish the status of court decisions as binding pronouncements of international law. Conventional wisdom would place equal or greater weight on the status of treaties and supranational court decisions as domestic law. Thus, for instance, states that have "incorporated" a treaty as par of domestic law, via constitutional or statutory provisions, are expecied to comply more readily with its requirements. After all, the treaty can then be enforced directly by domestic courts. This belief animates incorporation campaigns such as the drive to convince Britain to implement the ECHR through a domestic statute. ${ }^{127}$

Incorporation offers no guarantee, however, that domestic courts and their fellow branches of government will comply more readily with the judgments of the supranational tribunal charged with interpreting and applying the incorporated treaty. Incorporation, for instance, may trigger a KompetenzKompetenz struggle, ${ }^{128}$ in which domestic courts decide that they should be the ones to determine the extent to which the treaty provisions override or otherwise effect the interpretation and application of purely domestic law. ${ }^{129}$

the Court in any case to which they are parties"). Arucle $46(2)$ of Protocol No 11 contuins essentually identical language. See Protocol No. 11, supra note 93. an. 46(2)

126. See, e.g., P.J.G. KAPTEYN \& P. VERLOREN VAN TheniaAT, INTRODUCtTuN to tht LaW of tht. EuROPEAN COMMUNITES 38 (Laurence W. Gormley ed. 2d ed 1989) ("The exiensive powers of the Count of Justice ensure that the law is respected, as regards the functioning of the Community. in \& way that is without precedent in the law of international organisatuons."): Mera Pentukaınen \& Manun Scheinun. A Comparative Study of the Monitoring Mechanisms and the Important Instruthonal Framesworts for Hwnan Rights Protection Within the Council of Europe, the CSCE and the European Connumun, in MovrtokLvo HUMAN RIGHTS IN EUROPE 93, 104 (Arie Bloed el al eds.. 1993) ("When considering the auvantages of the ECHR system, ... the fact that the complaint procedures end with decisions which are legally binding upon the states parties . . . must be emphasized."); see also M.A Eissen. Linterachon des Junsprudences Constitutionnelles Nationales et de la Jurisprudence de la Cour Europeene des Drouts de l'Homme. in Conseil ConstTUtionnel et COUR EURopeenNe des Drotrs de L'Homme 137 (Domunque Rousseau \& Frederique Sudre eds., 1990).

127. See Unconventional Human Rights, Economist. Sept 24, 1944, at 56 In $1 \% 91$. Lord Ackner noted, in a decision holding that lack of proportionality was not a separate ground of revew under English administrative law, that until Parliament incorporated the Conventson into domestue liw, there was no basts upon which the proportionality doctrine appliad by the ECHR could be followed by the courts of the United Kingdom. See R. v. Secretary of State for the Home Dep'l (Ex Parte Bnnd), [|99|] I App Cas 696 (H L 1991).

128. The term "Kompetenz-Kompetenz" cames two separate meanings due to its unigins in German constitutional law. As used in discussions of the European Unton. it refers both to the powet of the Unon to determine (or enlarge) its own competences and to the power of the ECJ to determine which norms come within the sphere of application of Union law. The latter meaning is also known as judiclal Kompetenz-Kompetenz. For a discussion and addistonal sources, soe Theodor Schilling. The Autonomy of the Community Legal Order: An Analysts of Posstble Foundatons, 37 HaRV LNT'L LI 389. 406 (1996), and Weiler \& Haltem, supra note 68, at 413. See also Weiler. supra note 60. at 2414

129. For specific discussion of how this struggle manifests itself within the Union. see the European University Institute 1995 Working Paper Senes. The European Court and Nathonal Courts Doctrıne and Jurisprudence: Legal Change in lis Social Conrext, including JULIANE KOKOTt. THE EUROPEAN COURT

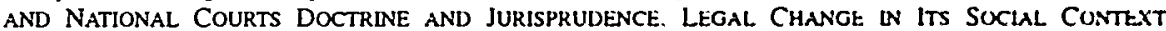
[REPORT ON GERMANY] 20 (European Univ. Inst., Florence, Working Paper RSC No 95/25. 1995), and Jens Plotner, The European Court and National Courts Doctrine aNo Jukisprudenct. Legal ChaNGE IN ITS SOCLAL CONTEXT [REPORT ON FRANCE] 11 (European Univ Inst. Florence. Working Puper 
Similarly, national governmental officials may feel that they can interpret the provisions of the treaty as incorporated into national law as well as the supranational tribunal can.

In fact, the empirical record concerning the impact of incorporation is mixed. On the one hand, Dutch courts were the first national courts to refer cases to the ECJ and to abide by its decisions even in the face of opposition from other branches of government, a posture that is difficult to separate from Dutch monism, or willingness to accept international law as automatically part of domestic law. ${ }^{130}$ Similarly, in his study of the legal authority of ECHR decisions in domestic legal proceedings, Andrew Drzemczewski observes: “[A] basic distinction may have to be made between those states in which the Convention possesses the status of internal law and those in which it does not." ${ }^{131}$ Jörg Polakiewicz and Valérie Jacob-Foltzer concur: Most important among the factors "which determine the impact of Strasbourg case-law in domestic law . . is certainly the status of the Convention in the hierarchy of internal norms." "132

On the other hand, France, also a monist state, resisted the direct effect and supremacy of European Community law, while both Italy and Belgium, dualist states, were more willing to comply. ${ }^{133}$ Observers of the ECHR also reach divergent conclusions. Mirielle Delmas-Marty, for instance, claims that "the correlation that one could have expected to find between the status of the Convention in the national laws and the degree of effectiveness or resistance that may be observed is not clearly established." 134 While international lawyers might be expected to have a professional interest in finding that refusal to incorporate the provisions of an international treaty into domestic law does not decisively determine the impact of those provisions, it is noteworthy that even scholars who are prepared to acknowledge the significance of this factor qualify their conclusions. ${ }^{135}$

RSC No. 95/28, 1995).

130. See Monica Claes \& Bruno De Witte, The European Court and national Coukts DOCTRINE AND JURISPRUDENCE: LEGAL CHANGE IN ITS SOCIAL CONTEXT [REPORT ON THE NETHERLANDS] 21 (European Univ. Inst., Florence, Working Paper RSC No. 95/26, 1995).

131. DRZEMCZEWSKI, supra note 90 , at 268.

132. Polakiewicz \& Jacob-Foltzer, supra note 91 , at 141.

133. See Alec Stone Sweet, Constitutional Dialogues In the European Community 10-13 (European Univ. Inst., Florence, Working Paper RSC No. 9S/38, 1995).

134. Mireille Delmas-Many, Abuses of the Reason of State, in THE EUROPEAN CONVENTION FOR THB Protection of HuMAN Rights 101, 103 (Mireille Delmas-Many \& Christine Chodkiewicz cds., 1992); see also Rudolf Bernhardt, The Convention and Domestic Law, in THE EUROPEAN SYSTEM FOR THB PROTECTION OF HUMAN RIGHTS, supra note 118, at 25, 40 ("Our conclusion is that irrespective of the formal incorporation of the Convention in the domestic law of States, Convention law and domcstic law are so closely interconnected that only together can they be adequately addressed.").

135. Andrew Drzemczewski, for example, writes:

Even in countries which have not incorporated the Convention, the judiciary may be inclined to take judicial notice of the findings of the Strasbourg organs (especially when the latter elaborate or clarify the meaning of the Convention's provisions), since there exists a general presumption that the courts should interpret domestic law in such a way as to make it consistent with the state's intemational obligations. 
Several factors reinforce the potential impact of international treaties even in the absence of incorporation provisions. First, where an intemational instrument is not accorded status as domestic law, either through a monist constitutional provision or specific implementation through a domestic statute, it may nevertheless be effective in filling gaps in domestic law. Drzemczewski, for example, attributes the impact of the European Convention on Human Rights on the Austrian legal system to gaps in Austrian domestic law concerning due process safeguards in criminal prosecutions. ${ }^{130}$ Several observers of the British judicial scene also comment on the relative willingness of English courts to look to the Convention in light of the absence of a written bill of rights in England. ${ }^{137}$ Second, courts can frequently draw on canons of interpretation requiring them to interpret domestic law consistently with international treaties, even where those treaties have not themselves been made self-executing. ${ }^{138}$

On balance, we conclude that the effectiveness of a supranational tribunal is enhanced where states make its decisions legally binding on the parties to the dispute before it. By contrast, our view of the legal status of an international agreement as domestic law is more tempered. Formal incorporation into domestic law appears to have some positive impact on enhancing a tribunal's effectiveness, suggesting that states should take steps to incorporate or otherwise to endow international law with the same force as domestic law. The ultimate impact of such direct or indirect implementation, however, will depend on a host of other factors, such as the relationship between courts and other branches of government and a state's openness to the international legal system. Thus, we include this factor in the checklist, but without the pride of place it might be expected to enjoy. Those who would put their faith in incorporation campaigns should be forewarned that such a step may be only the first step. Conversely, those who fear decisive political resistance to incorporation from the legislature or the executive should not lose hope.

\section{Factors Within the Control of the Judiciary}

Even assuming that the states party to an international agreement establishing a supranational tribunal are fully cooperative and establish all the above conditions to enhance its effectiveness, much remains for the tribunal itself to do. It is the ECJ itself that is popularly credited with the

\footnotetext{
DRZEMCZEWSKI, supra note 90, at 261.

136. See id. at 93.

137. See, e.g., Unconventional Human Righis, supra note 127, at 56 The Economist further notes that reliance on the European Convention has strengthened the power of lower Bntush courts vis-d-vis Parliament. See id.

138. See DRZEMCZEWSKI, supra note 90, at 261
} 
transformation of the Treaty of Rome from an international agreement into the constitution of the European Union, by convincing national courts to apply European Union law directly and supremely to national law. ${ }^{139}$ The ECJ benefited greatly from the structural relationship with national courts that Article 177 created, providing a ready-made entrée into national legal systems. Nevertheless, the Court still faced the task of wooing the national courts, convincing them to refer cases and to listen and respond to the resulting ECJ judgments. ${ }^{140}$

The ECHR has no structural provision equivalent to Article 177. It has instead faced a situation in which a number of national courts have been inclined to apply the law of the Convention, especially where the Convention has been incorporated into national law, without necessarily following the interpretations developed by the ECHR. ${ }^{141}$ It has thus had to rely equally on government officials and on national legislators to heed its judgments, a situation more typical of classic international tribunals.

In both cases, however, the question remains: Why have national actors listened and responded? More precisely, how did these two tribunals manipulate factors within their control to maximize their impact on the relevant national actors? This section of the checklist identifies those factors. They include the tribunals' awareness of their audiences, their demonstrated autonomy from political interests, their incremental style of decisionmaking, the quality of their legal reasoning, their dialogue with other supranational tribunals, and the forms of their opinions. Many of these factors overlap; many may strike readers as the standard elements of "good judging." We present them here as specific components of a sustained effort by two supranational tribunals to enhance their effectiveness.

\section{a. Awareness of Audience}

The ECJ and the ECHR have both been aware of constituencies for their

139. See supra note 60 and accompanying text.

140. The story as recounted here focuses primarily on the contributions of the ECJ itself to the establishment and strengthening of its relationship with the national courts. National courts, however, had independent reasons to listen and respond. The most comprehensive account of the motives of national judges is contained in ALTER, supra note 70, at 5-23. See also WALTER MATTLI \& ANNB-MARIE SLAUGHTER, CONSTRUCTING THE EUROPEAN COMMUNITY LEGAL. SYSTEM FROM THE GROUND UP: THE ROLE OF THE INDIVIDUAL LITIGANTS AND NATIONAL COURTS 20-27 (European Univ. Inst., Florence, Working Paper RSC No. 95/39, 1995) (using evidence from a country study to discuss three strands of judicial interest: judicial review, judicial competition, and promotion of substantive policies).

141. For general discussions on national courts' acceptance of the Strasbourg court's interpretations, see DRZEMCZEWSKI, supra note 90, at 268; and Polakiewicz \& Jacob-Foltzer, supra note 91, at 66. For discussion of specific countries, see DRZEMCZEWSKI, supra note 90 , at 270, which discusses Austria; Polakiewicz \& Jacob-Foltzer, supra note 91, at 72, which discusses Belgium; and id. at 129 , which discusses the Netherlands. The situation described in the text is similar to the relationship between the ECJ and supreme national courts, many of which have been noticeably more reluctant than lower national courts to refer cases to the ECJ and to follow its rulings. See ALTER, supra note 70, at 18-19. 
decisions other than the monolithic "states" that are their apparent creators and subjects. The ECJ has targeted both national courts and individual litigants. The ECHR has focused more on individual subjects of state governments. In both cases, the tribunals have recognized an audience beyond the parties to the case at hand and have crafted their opinions to encourage additional cases by appealing to both the material interests and professional ideals of prospective litigants or referring courts. They have also used these appeals to penetrate the surface of the state, linking up to different domestic political actors with actually or potentially divergent interests.

The ECJ helped create its own constituency by deliberately aiming many of its landmark opinions at individual litigants who stood particularly to gain from the enforcement of European Community law, from importers and exporters to individual taxpayers. Van Gend \& $\operatorname{Loos}^{142}$ is explicit on this score:

[T] he Community constitutes a new legal order . . . for the benefit of which the states have limited their sovereign rights, albeit within limited fields, and the subjects of which comprise not only Member States but also their nationals. Independently of the legislation of the Member States, Community law therefore imposes obligations on individuals but is also intended to confer on the.n rights which become part of their legal heritage. ${ }^{143}$

This passage served as an announcement that the ECJ was prepared to enforce the rights of individuals under the Treaty of Rome against the individuals' own state governments in instances where those governments proved recalcitrant about fulfilling treaty obligations of potential benefit to classes of individuals.

Van Gend \& Loos also reveals a keen awareness of the importance of establishing a good relationship with national courts, the sources of potential references under Article 177. The case involved one of the first references from a national court (the Dutch Tariefcommissie). The ECJ was anxious to encourage additional references while simultaneously establishing its own authority within the sphere of Community law. It thus adopted a strategy of manifest deference to those national courts acting within their proper sphere of jurisdiction, combined with an appeal to those courts to use Community law in exercising their primary function of protecting individual rights. ${ }^{1+4}$

142. Case 26/62, N.V. Algemene Transp. \& Expeditue Ondememing Van Gend \& Luos v Nederlandse administratie der belastingen, 1963 E.C.R. 1; see supra notc 62 and accompanyıng text

143. Van Gend \& Loos, 1963 E.C.R. at 12 (emphasis auded)

144. For instance, in response to a contention by the Belgian government that no ruling by the ECJ could have any bearing on further procecdings in the Tanefcommissie, the ECJ emphasized that $t 1$ was up to the national court to decide whether to seek assistance on questouns of Community law, and that the "considerations which may have led a national coun or tribunal to tis choice of questuons as well $\downarrow$ the relevance which it attributes to such questions in the context of a case before ut are excluded from review by the Cour of Justice." Id. at 11. After concluding that Arucle 12 of the Trealy of Rume was directly applicable to the national cours, the ECJ concluded that the actual application of the Antele on the specitic 
The ECJ's next task was to encourage direct references from lower national courts in the face of opposition from their own supreme courts. The Court responded by again emphasizing, court to court, the duties of the national courts to protect individual rights. Where such rights flow from supranational law, the ECJ declared, national courts have an obligation to enforce them in accordance with instructions from the ECJ rather than from higher national courts. ${ }^{145}$ Over time, the ECJ depicted itself as a partner of the national courts, collaborating with them to enforce Community law. National courts responded in kind, increasing the number of references under Article 177 from 9 in 1968 , to 119 in 1978 , to over 150 per year in the 1990s. ${ }^{146}$

This partnership ultimately has evolved into a form of powersharing in which national courts, particularly national supreme courts, communicate their preferences to the ECJ concerning the content and scope of European Community law. The German Constitutional Court has been the ECJ's most active interlocutor in this regard. It announced in the early 1970s that it would not accept the ultimate authority of the ECJ in cases involving the human rights of German citizens because the ECJ had not established a comparable system of human rights protections in European Community law. ${ }^{147}$ When

facts of the case presented was a matter for the Tariefcommissie to resolve. The court contented itself with a final declaration that "Article $12 \ldots$ produces direct effects and creates individual rights which national courts must protect." Id. at 16.

145. In Case 106/77, Amministrazione delle Finanze dello Stato v. Simmenthal S.p.A., 1978 E.C.R. 629, a lower Italian court asked the ECJ to resolve a conflict between a provision of Community law and an apparently conflicting provision of the Italian constitution, notwithstanding a decision by the Italian Constitutional Court that such conficts should be referred to the Constitutional Court itself. The ECJ held that the provisions of Community law

are ... a direct source of rights and duties for all those affected thereby, whether Member States or individuals, who are parties to legal relationships under Community law. This consequence also concerns any national cour whose task it is as an organ of a Member State to protect, in a case within its jurisdiction, the rights conferred upon individuals by Community law.

Id. at 643 . It followed that any provision of national law that threatened to impede the ability of national courts to enforce Community law was itself a violation of Community law and should thus be disregarded by the national court. See id. at $645-46$.

146. See BERMANN ET AL., supra note 63, at 245. This interaction between the ECJ and national courts has been described as a form of "judicial dialogue." Anne-Marie Slaughter, A Typology of Transjudicial Communication, 29 U. RICH. L. Rev. 99, 100, $135-36$ (1994). Commentators on the ECHR have also observed the beginnings of a similar dialogue between the ECHR and national courts. See Polakicwicz \& Jacob-Foltzer, supra note 91 , at 66. As Polakiewicz and Jacob-Foltzer write:

Faced with an ever-increasing case-law from Strasbourg, domestic courts have gradually abandoned their reserved attitude with regard to the Convention. We are witnessing the beginning of a true dialogue between the European Human Rights Coun and national jurisdictions whereby principles like the proportionality test that have been developed in certain national legal orders are taken up by the European Court of Human Rights and later accepted Id. in other countries as part of a common European standard.

147. See Internationale Handelsgesellschaft $\mathrm{mbH}$ v. Einfuhr- und Vorratsstelle fur Getreide und Futtermittel (Solange I), Entscheidungen des Bundesverfassungsgerichts [BVerfGE] [Federal Constitutional Court] 37, 271 (271-79) (1974) (F.R.G.), translated in [1974] 2 C.M.L.R. 540, 540-51 (concluding that Community law, which did not protect fundamental rights to the degree required by the constitution of the Federal Republic of Germany, would not be accorded priority over German law that was designed to 
the ECJ responded by establishing such a system, which blended a mixture of national and international human rights guarantees, the German court in turn softened its stance. ${ }^{148}$ In such cases, awareness of audience becomes responsiveness to audience, but such necessities are the ultimate fruits of a supranational tribunal's success.

Without the benefits of the structural provisions of Article 177, the ECHR has had to target a broader and more diffuse audience of individual victims of human rights abuses. ${ }^{149}$ One device that has served it well in this regard is the "doctrine of effectiveness." 150 According to this doctrine, the Convention's "special character as a treaty for the collective enforcement of human rights" "151 requires that its provisions be interpreted and applied so as to make its safeguards "practical and effective"152 rather than "theoretical or illusory." 153

"Practical and effective" in this context means a willingness to find for individual litigants against their national governments, a position the ECHR is quite willing to broadcast. ${ }^{154}$ Indeed, in Cossey' 1. United Kingdom. ${ }^{\text {ss }}$ dissenting Judge Martens described the ECHR as the "last resort protector of

protect those rights).

148. See In re Wünsche Handelsgesellschaft (Solange II), B VerIGE 73. 339 (377) (1986) (F R G). translated in [1987] 3 C.M.L.R. 225, 259 (concluding that the 14 years of ECJ pratituce since Solange I had created a climate of effective protection of fundamental raghts within Community las) Accordingly. the German court declined to police further the compatibility of European Community law with German fundamental rights. See Jochen A. Frowem, Recent Case, 25 COMmox MiKT L REV 201. 205 (1988), see also Weiler, supra note 60 , at 2428.

The German Constitutional Court's ambivalence regarding European Umon law was repested in its recent decision in a case challenging the constututionality of the Masstricht Treaty. which establushed the European Union. See Judgment of Oct. 12, 1993 (Brunner v Eurupean Union Tresly). B VertGE 89. 155 (F.R.G.), translated in [1994] 1 C.M.L.R. 57 The German coun tound the treaty constitutionsl, but unly so long as the competences of the European Union remamed sulficiently limiled to assure German citizens of the guarantees of democracy provided them in their consulution To keep the institutions of the liniun within these limits, the German coun proposed that "t enter into a "relduonship of co-uperation" with the European Cour of Justice, "under which [the ECJ] guaranlees protection of bassic rights in any particular case for the whole area of the European Communitues, and the [German] Constitutional Coun ian therelure restrict itself to a general guarantee of the constitutional standards that cannot be dispensed with " Id at 79.

149. The ECHR has not, however, ignored the important role that nationsl courts ean play in interpreting and applying the Convention. Thus, when a clamant taled to rase arguments basod on the Convention in a country whose courts gave its provisions direct elfect. the ECHR dismissed the case lur failure to exhaust domestic remedies. See Van Oosterwijck y Belgium, 40 Eur Ct H R (ser A) \& 16-17 (1980).

150. Bernhardt, supra note 105, at 306 (noting that the doctrunc of effectuveness means that the ECHR sees the Convention's object and purpose as the protection of the individual and that the interpretation of its provisions must guarantee that these protections become ellecuve)

151. Soering v. United Kingdom, 161 Eur C HR (ser A) At 34 (1989)

152. McCann v. United Kingdom, 324 Eur. Ct HR (ser A) dt 45 (1995), accord Lomadou 、 Turkey. 310 Eur. Ct. H.R. (ser. A) at 27 (1995).

153. Artico v. Italy, 37 Eur. Cl. H.R (ser A) at 16 (1980)

154. See, e.g., Ribitsch v. Austria, 21 Eur HR Rep 573. 577 (Commisston repurt) (stating that the "proceedings instituted under the European Convention on Human Right are nut simed 4 punishing the authors of violations, but at protectung the victums and providing redress for damuge caused by the dets of state responsibility"), aff'd, 336 Eur. Ct. H.R. (ser A) at 26-28 (1995)

155. 184 Eur. Cl. H.R. (ser. A) (1990) 
oppressed individuals."156 The ECHR is particularly active in interpreting the Convention "effectively" when reviewing the treatment of especially vulnerable groups. Its receptiveness on these questions signals to disadvantaged individuals throughout member countries the court's willingness to review carefully alleged violations of both procedural and substantive rights by their governments. ${ }^{157}$ With Protocol No. 11's entry into force, the court will find it easier to target individual claimants; for the first time, these claimants will be given direct access to the ECHR in every case. ${ }^{158}$

Individuals and their lawyers, voluntary associations, and nongovernmental organizations are ultimately the users and consumers of judicial rulings to redress a particular wrong or advance a particular cause or set of interests. Their power still ultimately depends on their influence with respect to state political institutions-courts, legislatures, administrative agencies, or executives. But an appreciation of the relationship between these social actors and the institutions of state government opens the door to deploying them as forces for expanding the power and influence of supranational tribunals. Just as a supranational tribunal may align its case law with the independent incentives facing some national courts, it can also address itself to the individuals and groups who are likely to be the ultimate beneficiaries of the enforcement of international norms and instruments.

\section{b. Neutrality and Demonstrated Autonomy from Political Interests}

Commentators have emphasized the link between a supranational tribunal's authority and its neutrality, here defined not only in terms of equidistance between litigants but also with regard to a tribunal's ability to explicate a decision based on generally applicable legal principles. The alternative is

156. Id. at 29 (Martens, J., dissenting).

157. See, e.g., Young v. United Kingdom, 44 Eur. Ct. H.R. (ser. A) at 25 (1981) ("Although individual interests must on occasion be subordinated to those of a group, democracy does not simply mean that the views of a majority must always prevail: a balance must be achieved which ensures the fair and proper treatment of minorities and avoids any abuse of a dominant position."); see also C.A. Gearty, The European Court of Human Rights and the Protection of Civil Liberties, 52 CAMBRIDGE L.J. 89, 108 (1993) ("In the Convention there are no articles dealing specifically with disadvantaged groups, and the Coun has had to deploy general provisions in the pursuit of its overall objectives; it is a case of protecting especially vulnerable individuals whose plight happens to be shared by others . ..."). Examples of the disadvantaged groups aided by the ECHR include prisoners, the mentally ill, and those involved in child custody cascs. See id.

158. Article 34 of Protocol No. 11 states:

The Court may receive applications from any person, non-governmental organisation or group of individuals claiming to be the victim of a violation by one of the High Contracting Partics of the rights set forth in the Convention or the Protocols thereto. The High Contracting Partics undertake not to hinder in any way the effective exercise of this right.

Protocol No. 11, supra note 93, art. 34; see Henry Schermers, Adaptation of the 11th Protocol to the European Convention on Human Rights, 20 EUR. L. REv. 559, 569 (1995). Many regard this section of the Protocol as a positive trend towards granting individuals more access to and presence in the ECHR. See, e.g., Schermers, supra note 115 , at 382 (criticizing the Protocol overall but adding that it does contain improvements, "especially by making the right of the individual petition compulsory"). 
"political" dispute resolution, in which the dispute resolver secks above all to satisfy or reconcile the parties' competing interests. ${ }^{159}$ The challenge for a court seeking to present itself as a judicial rather than a political body is thus to demonstrate its independence from both political authorities and political modes of dispute resolution. The judicial selection and tenure process (discussed in the first set of factors above) ${ }^{100}$ are obviously key factors here. In addition, a tribunal can to some extent manage perceptions of its impartiality by refusing to pander to the governments at whose sufferance it exists. As the history of supranational adjudication in Europe makes plain, both the ECJ and the ECHR have been willing to decide against governments in big cases. $^{161}$

Such willingness does not, however, imply that the tribunals are always aggressive in seeking to find treaty violations. To the contrary, they have often used procedural mechanisms to avoid reaching the merits of a dispute. Thus, both the ECHR and the Commission require claimants to satisfy all of the preconditions for the admissibility of their complaints, and the Commission has regularly dismissed claims where the petitioner failed to proffer evidence in support of his or her case. ${ }^{162}$ As a further guarantee of fairness, the ECHR decided in its earliest cases that it had the competence to reconsider a government's objections to admissibility after the Commission had rejected them, a doctrine that has resulted in cases being dismissed on appeal. ${ }^{163}$

159. A classic statement of this position is Lon Fuller's explication of the distuncure Iestures of adjudication. See Lon L. Fuller, The Fonns and Lmuss of Adjudication, $92 \mathrm{HAKV}$ L REV 353.365 .72 (1978). We fully recognize the decades of debate, both before and after Fuller's antucle, uver the valudity of the "law/politics" divide. Whatever the proper framing of the interaction between law and pollucs regarding the activities of a mature judicial tribunal, however, we contend that a young tnbunal must be very careful to draw and maintain a very basic version of this disunction with regusd to uther decisionmaking bodies.

Observers of the ECHR also stress the distunction beiween legal and political decistunmaking: Drzemczewski, for instance, notes that the decistons of the Commitiee of Ministers, a "politucal body." "afe likely to carry less weight than the reasoned judgments of the [ECHR]" Dk/kMC/tw Sk1, supra nute 90. at 323-24. Paul Sieghar concurs, emphasizing that the Committee of Minusters "is not an impartud tnbunal composed of independent individuals, but a poltucal body made up of governmental representatues " PAVL SIEGHART, THE INTERNATIONAL LAW OF HUMAN RIGHTS 27 (1983)

160. See supra Subsection IIl.B.I.a.

161. See, e.g., McCann v. United Kingdom, 324 Eur Cl HR (ser A) at 174 11995) (hnding a violation of the Convention in the killing of IRA service unit members). Luisiduu $\vee$ Turkey, $310 \mathrm{Eut} \mathrm{Cl}$ H.R. (ser. A) at 18 (1995) (rejecting imponant aspects of Turkey's reservattons on the ngth of individual petition and the court's jurisdiction); Funke v. France, 256-A Eur C HR (ser A) at 22 (169) 3) (thnding a violation of the Convention resulting from seizure of documents from the spplicani's hume and impusing monetary sanctions for failure to produce additional documents). Cases C-6/40 \& C.9/\%), Franturich : Italy, 67 C.M.L.R. 66 (1991) (recognizing the right of pnvale parties to sue lor damages caused by the state's failure to implement Communty law); Case C.221/89. The Queen v Secretary of Stale tor Trunsp (Ex parte Factortame Ltd.), 1991 E.C.R. 1-3905 (Invalıdatung Bntush laws on the registratuon ol shipping vessels); Case 176/84, Commission v. Hellentc Republic. 1987 E C R 1193 (invalidalung a Greek law that effectively prohibited the sale of forcign beer in Greecic)

162. See ROBERTSON \& MERRILLs, supra note 81. at 264. 273 (chatactenzang the Commission's admissibility decisions as strict and notung that under current prattic $90 \%$ of cases ate dismissed at the admissibility stage).

163. See, e.g., Van Oosterwijck v. Belgium, 40 Eur Ct H R (ser B) at 26 (1980) Thus Juxtrme is not without its critics, however. See, e.g., Brolicek v Ilaly. 167 Eur CI HR (set A) 422.28 (1989) 
Similarly, the ECJ has refused to accept referrals where no genuine controversy concerning an issue of Community law exists, even if the national court or administrative body believed that such issues should be decided. ${ }^{164}$ The Court thus has assured member states that it will not decide issues of Community law that are not directly relevant to the disputes before national courts. ${ }^{165}$

For fledgling tribunals, however, counseling autonomy and neutrality presents a dilemma. Members of such tribunals may feel that their authority and legitimacy depends on not antagonizing those governments on which their power ultimately depends, and on proceeding diplomatically. To the extent that a particular tribunal is composed of some individuals from nations without a tradition of an independent judiciary, and to the extent the states under the jurisdiction of the tribunal do not have such a tradition, accommodationist pressures are likely to be particularly strong. In this context, neutrality can come to mean "avoiding political confrontation," a euphemism for choosing not to remind governments of their legal obligations. ${ }^{166}$

The solution to this dilemma turns on a prior conception of identity as a court, or at least as a quasi-judicial tribunal. "Court-ness" does not rule out incrementalism or strategic decisionmaking, as discussed further in the next subsection. It does, however, mandate decisionmaking premised (at least formally) on principle rather than power. As studies of "legalization" of international decisionmaking suggest, secrecy and compromise are the hallmarks of diplomacy, not law. ${ }^{167}$ Thus, tribunals must be willing to brave political displeasure, searching always for generalizable principles, even as they search for formulations or procedural mechanisms to render the principles more palatable to the states concerned.

\section{c. Incrementalism}

Bold demonstrations of judicial autonomy by judgments against state interests and appeals to constituencies of individuals must be tempered by incrementalism and awareness of political boundaries. The ECJ originally borrowed a leaf from Chief Justice John Marshall's book, edging principles

(separate opinion of Martens, J.).

164. See, e.g., Case 244/80, Pasquale Foglia v. Mariella Novello (Foglia II), 1981 E.C.R. 3045.

165. See id. at 3066-77.

166. Robertson and Merrills note that the Commission, in its early years of operation, dismissed at the admissibility stage $98 \%$ of all petitions filed, a figure they characterize as unduly high. See ROBERTSON \& MERRILLS, supra note 81 , at 264 . Beddard concurs that the Commission "trod very carefully and timidly in its early days," but he maintains that this early caution was "essential for the Convention's success." BEDDARD, supra note 75, at 227.

167. See, e.g., John H. Jackson, The Legal Meaning of a GATT Dispute Settlement Report: Somte Reflections, in TOWARDS MORE EFFECTIVE SUPERVISION BY INTERNATIONAL ORGANLLATIONS 149, 151 (Niels Blokker \& Sam Muller eds., 1994). 
forward while deciding for those most likely to oppose them in practuce. ${ }^{\text {las }}$ Only skilled lawyers could predict the far-reaching outcomes of the early landmark cases, the pregnant potential in a carefully couched phrase. Each case supported the next-from direct effect of selected treaty articles, to the supremacy of Community law over national law, to the direct effect of directives-but the Court took its time and generally responded to strong political signals that it had gone too far. ${ }^{169}$

Overall, the forms and language of law insulated an emerging legal community from the political realm. Again, this is not to suggest a strict divide between law and politics, but rather a mediated interaction. The overall boundaries for the ECJ are set by the political institutions of the Community, above all the member states. If the Court pushes teleological interpretation of the treaty-a mode of interpretation biased toward achieving the ever closer union described in the Treaty's preamble- too far too fast, the member states can act to curtail its jurisdiction or urge their national courts to disregard its judgments. ${ }^{170}$ They might also seek to shift the composition of the Court.

The Court has thus used the Commission of the Community, the executivepolitical branch of the Community, as a political bellwether, watching its position on major cases as a sign of what the political traffic will bear. ${ }^{171}$

168. As Weiler explains:

There was a slow change of climate and ethos [in the early days of the ECJ] whereby strict enumeration was progressively. relentlessly. but never dramatically. croded Extension. absorption, incorporation, and powers implied by the Coun, all feed on each whet in cog-and. wheel fashion so that no dissonances are revealed withn the consututuonal drchutecture tiselt as it is changing.

Weiler, supra note 60, at 2447 (analogizang this tactic to U S Chit Jusuce John Marshall's reasuning in McCulloch v. Manland, 17 U.S (4 Wheat.) 316, 421 (1819)), see also ALThk, supra nute 70, at 282 (noting how the ECJ followed a well-known judicial pracikc. expanding "its junsdictionsl duthorily by establishing legal principles, but not applying the principles to the cases at hand")

169. The Cour retrenched somewhat in the face of strong politucal uppousition to the ERTA case. Case 22/70, Commission v. Counc1, 1971 E.C.R. 263, in which tt held that powers granted to the Cummissiun of the Community in internal Community matters implied concomitant powers to reptesent the Cummunty

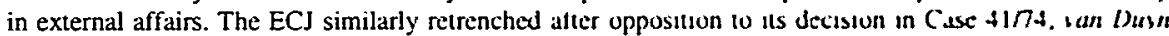
v. Home Office, 1974 E.C.R. 1337, in which the Court granted direct ellect to sume cistegunes ol directures

170. In 1992, Chancellor Helmut Kohl of Germany volced distress over what he sal ts "unu arr unted judicial activism": "IThe Court of Justice] does not only exen its competencies in legal malters. but gues far further. We have an example of something that was nut wanted in the beginning " Chuncellor Kohl Accuses the Court of Going Beyond Its Competencies: The "Palctis and Buctel Cass. Elkort. Ot it. 1992, at 9. Walter Mattli and Anne-Mane Slaughter argue that, nowwthstanding this ittetonc, menter states recognize that although "they can hmit the coun's sphere of opersuon by curtaling us juriseliction, they cannot intervene within that sphere by asserting their preferences dyunst the court's creeping extinsiun ot community norms." Walter Matds \& Anne-Mane Slaughter, Law and Polines in the European Unon A Reply to Garrett, 49 INT'L ORG 183, 189 (1995)

171. After analyzing 11 landmark cases, one experienced Coun w dtcher cuncluded that "the Cuun has been led by the Commisston in the inexorable progression toward more legal integration and more Community power. The close alliance between the [twol has probsbly allevisted sume of the cuncern members of the Cour may have felt regarding the legitimaty and siceptante of ats rulings " Stetn. supra note 60 , at 24. Judges themselves have referred to the overall climate of the Community as a rationale lor more or less activism. Most recently, as accusations of undue atts ism hase been llying trum imponant politicians within the Community, the Coun has pulled in is homs a bit See Giuseppe Federuo Manim \& David T. Keeling, Language, Culture and Polisics in the Life of the European Court of Justuce. 1 Colum. J. EUR. L. 397, 406-08 (1995) (noting the recent minimalist posture of the Cuurt due in part to 
Over the last decade, in response to political forces and the Maastricht Treaty, the Court has visibly been practicing restraint. ${ }^{172}$ It is also discovering the "passive virtues"173 of rulings that dispose of contentious issues on grounds of jurisdiction (admissibility) and justiciability. In the celebrated Irish abortion case, for instance, the ECJ held that the question of whether Ireland could regulate abortion fell outside its competence, ruling instead only on the much narrower question of whether Ireland could prevent Irish citizens from traveling to England to get abortions. ${ }^{174}$ In other decisions, the Court has proven increasingly willing to share power with national courts-perhaps for reasons of docket crowding as much as of political expediency. Much of the pattern of ECJ jurisprudence in the 1990s, however, has demonstrated its renewed awareness of the virtues of incrementalism.

The ECHR has also demonstrated an acute awareness of the tension between the preferences of national decisionmakers and the requirements of the European Convention. To address this tension, the ECHR has developed the concept of a "margin of appreciation," acknowledging an area of discretion for national governments when applying and interpreting the treaty. ${ }^{175}$ The court has emphasized that some deference is appropriate because it is not always as well-equipped as national actors to strike an appropriate balance between competing interests in complex areas of law and policy. ${ }^{176}$ It has also stressed, however, that any discretion to national decisionmakers is limited by a "European supervision" that "empower[s the ECHR] to give the final ruling" on whether a challenged practice is compatible with the Convention. ${ }^{177}$

In striking the balance between deference and independent judicial review, the ECHR looks to the degree of consensus or harmony among the national

the disenchantment of judges who once believed they alone could implement integration).

172. See id.

173. BICKEL, supra note 23, at 267.

174. See Case C-159/90, Society for the Protection of Unborn Children, Ir. v. Grogan, 1991 E.C.R. I-4685.

175. In an early argument before the court, the President of the Commission explained the margin of appreciation doctrine as follows:

The concept of the margin of appreciation is that a government's discharge of [its] responsibilities is essentially a delicate problem of appreciating complex factors and of balancing conflicting considerations of the public interest; and that, once the Commission or the Court is satisfied that the Government's appreciation is at least on the margin of [its] powers ...., then the interest which the public itself has in effective government and in the maintenance of order justifies and requires a decision in favour of the legality of the Government's appreciation.

Lawless v. Ireland, 1 Eur. Ct. H.R. (ser. B) at 408 (1960-1961). For a detailed discussion of the margin of appreciation doctrine, see Howard CHARLES Yourow, THE MARGIN OF APPRECIATION DOCTRINE IN THE DYNAMICS OF EUROPEAN HUMAN RIGHTS JURISPRUDENCE (1996). See also MERRILLs, supra note 77, at $136-59$.

176. See, e.g., Handyside v. United Kingdom, 24 Eur. Ct. H.R. (ser. A) at 22 (1976) (noting that the ECHR cannot assume the role of national courts and legislatures when balancing conflicting interests); Belgian Linguistics Case, 6 Eur. Ct. H.R. (ser. A) at 34-35 (1968) (stating that the court cannot assume the role of national authorities).

177. Sunday Times v. United Kingdom, 30 Eur. Cl. H.R. (ser. A) at 36 (1979); see also Barfod v. Denmark, 149 Eur. Ct. H.R. (ser. A) at 12 (1989). 
laws of signatory states in deciding how wide or narrow a margin to afford the respondent state in the case before it. ${ }^{178}$ This approach allows the court to narrow the margin of discretion allotted to national governments in an incremental fashion, finding against state respondents according to the underlying treatment of the right at issue within other European nations. ${ }^{179}$ As a result, the ECHR is able to identify potentially problematic practices for the contracting states before they actually become violations, thereby permitting the states to anticipate that their laws may one day be called into question. ${ }^{180}$ In the meantime, a state government lagging behind in the protection of a certain right is allowed to maintain its national policy but is forced to bear a heavier burden of proof before the ECHR-whose future opinions will turn in part on its own conception of how far the "trends" in European domestic law have evolved. ${ }^{181}$ The conjunction of the margin of appreciation doctrine and the consensus inquiry thus permits the ECHR to link its decisions to the pace of change of domestic law, acknowledging the political sovereignty of respondent states while legitimizing its own decisions against them. ${ }^{182}$

178. The ECHR has applied the consensus principle in a few recent cases See, e $g, X$ y Unted Kingdom, No. 75/1995/581/667, slip op. at 13 (Eur. Ct HR Apr 22. 1997) ("The Coun observes that there is no common European standard with regard to the granting of parental nghts to transsexuals Since the issues in the case, therefore, touch on areas where there is litte common ground umongst the member States of the Council of Europe and, generally speaking. the law appears to be in a transilional stage, the respondent State must be afforded a wide margin of appreciation "): Otto-Preminger Inst. $v$ Austria, 295-A Eur. C. H.R. (ser. A) at 19 (1994) (finding that the lack of a uniform European conception of rights to freedom of expression "directed against religtous feelings of others" dictates a wider margin of appreciation); see also Paul Mahoney, Universaliny Versus Subsudianty in Strasbaurg Case Law on Free Speech, 1997 EUR. HUM. RTS. L. REv. 364. 368-71.

179. See Yourow, supra note 175, at 194 (arguing that the existence of progressive European consensus leads to a narrower margin and applicant outcomes favorable to applscants). Nadine Strussen. Recent U.S. and International Judicial Protection of Indwidual Rightis: A Comparame Legal Process Analysis and Proposed Synthesis, 41 HASTINGS L.J. 805, 862 (1990) (arguing that consensus is an important factor influencing the scope of deference to state decisionmalkers)

180. See Laurence R. Helfer, Consensus, Coherence and the European Convenhon on Human Rights. 26 CORNELL INT'L L.J. 133, 141 (1993); see also MERRILLS, supra nute 77, al 81 (interpreung the ECHR's statement in Rees v. United Kingdom, 106 Eur. Ct H.R. (ser A) at 19 (1986). that - (t)he need for appropriate legal measures [to proted transsexuals] should therefore be kept under review having regard particularly to scientific and societal developments" as a "strong hint that while Briush practuce currently satisfied [the Convention], the court's duty to interpres the Convention as a Ising instrument may lead it to a different conclusion in the future").

181. See Strossen, supra note 179, at 862; see also MERkiLLs, supra note 77. at 7.4.75 (discussing Marckx v. Belgium, 31 Eur. Ct. H.R. (ser. A) at 15 (1979)) In Marckx, the ECHR decuded that Belgian legislation distinguishing between legitimate and illegitumate children contravened the tight to respeet for family life. In finding a violation, the ECHR stressed that European laws were evolving significanly loward equal treatment. See Marckx, 31 Eur. Ct. H.R. (ser. A) at 16 Merrills argues, however, that the count overstated the evolution of state practice. See MERRILLs, supra note 77, an 74

182. See YOUROW, supra note 175, at 196 ("IT)he Court will continue to build its authonty incrementally and cautiously, retaining the margin doctrine, pinning it to the secunty of the consensus principle ... ."); see also Goodwin v. Unitod Kingdom, 22 Eur H R Rep 123, 143-44 (1996) (Eur Cl. H.R.) (acknowledging national discretion expressly in the context of finding that the government had violated a journalist's freedom of expression). 


\section{d. Quality of Legal Reasoning}

Judges on supranational tribunals tend to attribute their relative success or failure, according to their own measures, to the quality of their legal reasoning. Judge Mancini, for instance, notes that approximately ninety-five percent of national courts in the European Community accept ECJ rulings. ${ }^{183}$ "Why did this happen?" he asks. ${ }^{184}$

The only reason I can see ... is the cleverness of my predecessors. If what makes a judge 'good' is his awareness of the constraints on judicial decision-making and the knowledge that rulings must be convincing in order to evoke obedience, the Luxembourg judges of the 1960 s and 1970 s were obviously very good. ${ }^{185}$

The early ECJ judges "developed a style that may be drab and repetitive, but explains as well as declares the law"186 and they followed a "courteously didactic method." 187 Judge Ulrich Everling concurs, crediting the Court with "creat[ing] its own legitimacy primarily by the internal logic and consistency of the actual results expressed in its judgments and by the significance of those results for the development of the Community legal order."188

Joseph Weiler, one of the most sophisticated observers of the ECJ from both a legal and a political perspective, lists formalism as a principal reason for the remarkable record of the ECJ in convincing the national courts to follow its lead in building a Community legal system supreme over national law. ${ }^{189} \mathrm{He}$ refers to the "per se compliance pull of a dialogue conducted between courts in legalese. Courts are charged with upholding the law."190 One of the sources of this "compliance pull," in his view, is "the legal language itself: the language of reasoned interpretation, logical deduction, systemic and temporal coherence-the artifacts that national courts would partly rely on to enlist obedience within their own national orders."

183. See Mancini, supra note 60 , at 595.

184. Id.

185. Id. at 605 .

186. Id. at 606 .

187. Id.

188. Ulrich Everling, The Court of Justice as a Decisionmaking Authority, 82 MiCH. L. REv. 1294, 1309 (1984). He notes further: "The inherent power of persuasion of their judgments entitles courts to expect acceptance by those affected by the decisions." Id. at 1308. For the views of yet another member of the ECJ, see Thijmen Koopmans, The Birth of European Law at the Crossroads of Legal Traditions, 39 AM. J. COMP. L. 493, 505 (1991), which attributes the attention paid by national courts to the ECJ's reasoning in part to "the intellectual strength of its comparative methods."

189. See Weiler, supra note 103, at 510-19.

190. Id. at 520-21.

191. Id. at 521. Weiler borrows the term "compliance pull" from Thomas Franck, who uses it to motivate his important study of the sources of legitimacy of international law. See Thomas M. Franck, Legitimacy in the International System, $82 \mathrm{AM}$. J. INT'L L. 705 (1988). Franck reasons that compliance pull flows from legitimacy, and that legitimacy in turn derives from four attributes: determinacy, pedigrce, coherence, and adherence. See id. Weiler's formulation in the text substantially overlaps Franck's definition 
The ECHR has also benefited substantially from the quality of its reasoning, at least according to experienced observers. Polakiewicz and JacobFoltzer conclude their study by noting that, with a few rare exceptions, the ECHR has "never been openly defied by national cours." this "persuasive authority" in large part to "the weight of the Court's arguments."193 Francois Ost concurs, finding "the judgments of the Court [to be] exceptionally well reasoned.... Each of the questions it seeks 10 answer... is scrupulously examined as to the facts, the law and the practice . ..."194 And for J.G. Merrills, looking ahead, the factor that "will ultimately determine the importance of the European Cour's contribution is the quality of the work.... [I]n the last analysis its contribution to the development of the law depends on the technique to be found in its decisions." 195

Although these scholars would be less likely to agree on precisely what elements or attributes make legal reasoning good, they would probably all acknowledge the value of "systemic and temporal coherence," to borrow Weiler's phrase, ${ }^{196}$ or, in Thomas Franck's formulation, "coherence" and "adherence." 197 Merrills, for instance, attributes the "wider significance" of the Court's judgments to its consistent efforts "to justify its decisions in terms which treat its existing case-law as authoritative. In other words, it follows judicial precedent." ${ }^{\text {"198 }}$ Adherence to precedent, even when used only as authoritative guidepost and not as binding obligation, ensures a minimum degree of both temporal and systemic consistency.

In a social or legal culture that venerates tradition for its own sake, consistency with earlier decisions provides an autonomous bulwark of legitimacy. It also provides a crucial monitoring device to facilitate judicial

of each of these attributes.

192. Polakiewicz \& Jacob-Foltzer, supra notc $9 !$. At $1+1$

193. Id.

194. Francois Ost, The Original Canons of Interpresanon of the European Court of Hunan Rights. in THE EUROPEAN CONVENTION FOR THE PROTECTION OF HUMAN RIGHTS, supra nute 134. at 283, 283-84

195. MERRILLS, supra note 77, al 18-19.

196. Weiler, supra note 103 , at $520-21$.

197. FRANCK, supra note 34, at 152. Franck defines coherence as the precept that rules must contorm to principles of general applicability. See id. Coherence endows a rule or rulemaking institution with authority by providing "a reasonable connection between a rule or the application of a rule. to (1) its own principled purpose, (2) principles previously employed to solve sımilar problems. and (3) a lattice of principles in use to resolve different problems." Id. at 147-48 (cmphasis omitted) Auherence connects legitimacy to Franck's theory of the intemational rule system Adherence is the "vertical nexus between a primary rule of obligation ... and a hierarchy of secondan' rules idenufying the sources of rules and establishing normative standards that define how rules are to be made. interpreted. and applicd " Id at 184

198. MERRILLS, supra note 77, at 12. The ECHR uself has proclatmed a general pnntiple of fidelity to precedent as "being in the interests of legal certannty and the orderly develupment of the Conventuon case-law." Cossey v. United Kingdom, 184 Eur. C. H.R. (ser A) at 14 (1990) See genterally Matthjs de Blois, The Fundamental Freedom of the European Court of Human Raghts, in TH: DYNasics of THE PROTECTION OF HUMAN RIGHTS IN EUROPE, supra note 115, at 35, 47 (describing precedential decisionmaking as motivated, not only by a desire-often commerclally motuvated-lor predictubtluy. but also by a deeper "quest for rationality" that is a predominant factor in the theory of law) 
accountability, allowing concerned constituents to track judges' fidelity to selfimposed rules. It is not, however, a guarantee of analytical quality. Later decisions can only be as good or bad as their predecessors. If Van Gend \& $\operatorname{Loos}^{199}$ were widely regarded as a poorly reasoned opinion, consistency with its basic premises and principles would presumably be less desirable. It follows that an additional increment of legitimacy must flow from the quality of the decisions themselves, both past and present.

We search thus for a set of more fundamental attributes of sound legal reasoning, the qualities that Weiler encompasses when he refers to "reasoned interpretation" and "logical deduction." "200 Yet, it is here that assessments of quality diverge, based on the type of legal reasoning and the logical mode a particular author prefers. Merrills stresses clarity of communication, persuasiveness, and completeness. ${ }^{201}$ Ost points to "the injection ... of certain indeterminate elements ( . . elastic criteria, methods of balancing conflicting interests, proportionality)" that forsake binary logic in favor of the flexible evolution of a few general principles. ${ }^{202}$ Mary Ann Glendon highlights the ECHR's "searching and tentative style ..., its open wrestling with the weaknesses as well as the strength of [its] positions." ${ }^{203}$ In short, and not surprisingly, scholarly evaluation of the ECJ and ECHR reflects many of the same debates about the distinctive and effective attributes of legal reasoning found in any national or international jurisprudential literature. These debates are likely to be similarly insightful-and similarly inconclusive.

We suggest that the precise nature of the reasoning involved, whether deductive, syllogistic, analogical, or some combination of these styles, is less important than that judicial decisions be reasoned in the first place: Reasons should explain why and how a particular conclusion was reached. To reason, in this context, means to give reasons for a particular result, regardless of the logic or mode of reasoning underlying those reasons. ${ }^{204}$ The giving-reasons requirement is the prerequisite for the exercise of persuasive rather than

199. Case 26/62, N.V. Algemene Transp. \& Expeditie Onderneming Van Gend \& Loos v. Nederlandse administratie der belastingen, 1963 E.C.R. 1.

200. Weiler, supra note 103 , at 521 .

201. See MERRills, supra note 77, at 26-28.

202. Ost, supra note 194, at 312.

203. MARY ANN GLENDON, RIGHTS TALK 155 (199!). Glendon goes on to note that the ECHR judges "have become proficient at the principled, modest, collegial, flexible, pragmatic techniques of judicial decision-making that were once the pride of the American common law." Id. at 157.

204. Martin Shapiro reminds us of Carl Friedrich's proposition that "in the Western tradition, the very concept of political authority . . . implies the capacity to give reasons." Martin Shapiro, The Giving Reasons Requirement, 1992 U. CHI. LEGAL F. 179, 181 (citing Carl J. Friedrich, Authority, Reason, and Discretion, in AUTHORITY 28 (Carl J. Friedrich ed., 1958)); see also Fuller, supra note 159, at 366 ("Adjudication is . . . a device which gives formal and institutional expression to the influence of reasoned argument in human affairs."). Merrills makes the point equally succinctly as applied to the ECHR: "The Court should support its decisions with adequate reasons because the provision of a reasoned decision is the raison d'être of a court of law." MERRILLS, supra note 77, at 30. 
coercive authority, the assurance that "the authority of a judgment derives from its intrinsic rationality rather than from an 'argument' of authority."20s

Courts can give reasons in many different ways. ${ }^{200}$ What form of reasongiving is most likely to be persuasive? We draw here on the school of thought that equates the explication of a judicial decision with the recognition, albeit not the reconciliation, of competing social, political, and economic values. ${ }^{207}$ An opinion that systematically canvasses the arguments for and against a particular position, approving some and answering or rejecting others, is a public acknowledgment that there are a range of different perspectives on a particular issue. These perspectives often are informed either by different fundamental values or at least by different priorities in the difficult task of choosing one set of values over another and assessing the costs and benefits of different choices. For Ost, this mode of explanation is 'the 'casuist' method of pro et contra," whereby "the Cour progresses to its final choice without failing to confront the objections to its position and without minimising what hesitations are to be overcome."208

This method has both psychological and political benefits. First, it dignifies the opposing arguments, signaling the proponents of these arguments that they have been heard and recognized as important participants in a debate.

205. Ost, supra note 194, at 284; see also H Patnck Glenn. Persuastse Authorin. 32 MCGILL L J 261, 263 (1987) (defining persuasive authonty as "authonty which altracts atherence as upposed to obliging it").

206. Anglo-Saxon lawyers are perhaps most forcefully reminded of this point when they contrast common law with civil law decisions. Michael Wells summarises the difference between Amentan and French decisions as follows: "Rather than a reasoned and candid essidy. an opinion in the highest courts [in France] is a terse and opaque summary of the outcome and the reasons for " " Michael Wells. French and American Judicial Opinions, 19 YALE J. INT'L L. 81.92 (1994) Both decisions are "reasuned." but the stylistic and structural differences reflect a divergence of much deeper premises concerning the function of judicial decisions and the role of cours in socicty:

For many Americans, the opinion is a vehicle for selting forth the judges vews of the substantive considerations bearing on the outcomes of cases, as well as the interplay between policy concerns and such formal constrants as precedent and rules French judges begin from a radically different premise. In their view, the role of the opinion is to apply setiled law to the facts, or rather, to create the appearance that the court is merely applying law to fact

Id. But see Mitchel de S.-O.-l'E. Lasser, Judicial (Self-)Portraits-Judicial Discourse th the French Legal System, 104 YALE L.J. 1325, 1342-43 (1995) (descnbing the traditional role of a French judge as a "syllogism machine" and countering this portrayal with the assertion that there exists an altematuve conception-the "unofficial portrait" of the French civil judge)

207. Cass Sunstein offers a forceful recent exposition of this postion See CASS R SUNSTEL, LEGAL REASONING AND POLITICAL CONFLICT at viii (1996) ("When legal reasoning operales dt its best. participants in law are attuned to the fact that people legilumately disagree on basic principles They try to resolve cases without taking sides on large-scale soctal controversies They produce incompletely theorized agreements on particular outcomes, a central feature of legal reasoning "). of EDWARD H LeVI. As INTRODUCTION TO LEGAL REASONDG 5 (1949) (arguing that reasoning by example, in the sense of presenting "competing analogies" to a courn, "bnngls] into the liw the common tdeas of the soctely")

208. Ost, supra note 194, at 284. Merrills agrees, quoting Hersch Lauterpateht for the proposition that "governments as a rule reconcile themselves to the fact that their case has not been successful-provided the defeat is accompanied by the conviction that their argument was considered in all its relevant aspects ${ }^{\cdots}$ MERRILLS, sUpra note 77, at 28 (quoting HERSCH LAUTERPACHT. THE DEVELOPMENT OF INTERNATIUNAL LAW BY THE INTERNATIONAL COURT 39 (1958)) 
participants whose arguments must be answered. ${ }^{209}$ Second, and relatedly, it suggests that these arguments could still prevail in another case, when the balance of fact and circumstance might tip the other way. Third, it presents the law as a carefully woven tissue of opposites, the fabric of a diverse community. ${ }^{210}$ Fourth, this self-presentation of the law fosters a dialogue between judges, lawyers, politicians, and even lay people, as the court's response to each argument can be responded to in turn. If the giving-reasons requirement bolsters a court's legitimacy by justifying its conclusions in terms of a particular polity's legal traditions and underlying social, economic, and political values, a casuist mode of presentation recognizes the inevitability and validity of debate on many if not all of these points while nevertheless insisting that such debate can ultimately produce a determinate and considered outcome. Judicial decisionmaking thus itself becomes a mode of collective deliberation. ${ }^{211}$

These arguments in favor of casuistry can be further grounded both in political philosophy and political science. As a matter of political philosophy, they emphasize the values of individual dignity and democratic participation. ${ }^{212} \mathrm{~A}$ reasoned opinion assures individual litigants that their day in court was meaningful, in that their arguments were actually heard by the judge. The judge's opinion both disseminates their arguments and dignifies them with a response. As a matter of political science, the arguments in favor of the casuist mode are arguments with "microfoundations," in the sense that

209. See Glendon, supra note 203, at 155-56.

210. We borrow this conception of the law from James Boyd White, who praises "openness" in judicial opinions as a means of exposing to the reader "the grounds upon which [the judge's] judgment actually rests, with as full and fair a statement of her doubts and uncertainties as she can manage." JAMBs BOYD WHTTE, JUSTICE AS TRANSLATION 224 (1990). Such openness would both reflect and compel "the suspension of judgment, ... perhaps the central virtue for the lawyer." Id. It would also confirm that the art of law is not that of linear reasoning to a sccure conclusion, but an an, fundamentally literary and rhetorical in kind, of comprehension and integration: the ant of creating a text-a mind and a community-which can comprise two things at once, and two things pulling in different directions. In speaking for one side as a lawyer, or for one result as a judge, that is, the legal mind should recognize (implicitly in the lawyer's case, explicitly in the judge's) what can be said for the other, thus by an an of integration creating a world in which differences can coexist.

Id. at 224-25.

211. Sunstein relates this view of judicial decisionmaking to a Madisonian model of deliberative democracy. See SUNSTED, supra note 207, at 195-96.

212. Frank Michelman identifies "dignity values" and "participation values" as two of the four types of values that are implicitly furthered by allowing people to litigate. See Frank I. Michelman, The Supreme Court and Litigation Access Fees: The Right To Protect One's Rights, 1973 DUKE L.J. 1153, 1172. Michelman argues,

Dignity values reflect concern for the humiliation or loss of self-respect which a person might suffer if denied an opportunity to litigate. Participation values reflect an appreciation of litigation as one of the modes in which persons exert influence or have their wills 'counted' in societal decisions they care about.

Id. (emphasis omitted). For a discussion of the continuing acknowledgment of the value of individual dignity in the rules regulating litigation in the United States, see Jerry L. Mashaw, The Supreme Court's Due Process Calculus for Administrative Adjudication in Mathews v. Eldridge: Three Factors in Search of a Theory of Value, 44 U. CHI. L. REV. 28, $49-52$ (1976). 
they offer an account of how the incentives of key individuals could be shaped in support of judicial authority. ${ }^{213}$ Lawyers and litigants who are convinced that their arguments have been heard and carefully considered are more likely to conclude that the judicial system is sufficiently fair to decide in their favor in a subsequent case, and perhaps to feel partially vindicated even on the losing side.

In sum, many commentators seeking to analyze the success of the ECJ and the ECHR emphasize the fact of legal reasoning, in the sense that judicial opinions are reasoned at all, as much as the quality of that reasoning. Both courts provide reasons for their decisions and create a framework within which reasoned debate can be conducted by acknowledging the weight of precedent. The ECJ may seem more lax in this regard than the ECHR, yet the detailed and careful analyses of the Advocate General often compensate for the terseness of the actual text of an ECJ decision.

Once the obligation to give reasons for a paricular decision is acknowledged, we suggest further that a casuist mode of reaching or, at least, presenting a particular decision may have particular benefits for bolstering judicial authority and legitimacy. A supranational court, in particular, is essentially in the business of constructing its own polity. defining the boundaries of a legal community constituted by adherence to an international instrument. A mode of judicial decisionmaking that acknowledges competing values while emphasizing dignity and democratic participation has a particular value in this context.

\section{e. Judicial Cross-Fertilization and Dialogue}

The ECJ and the ECHR enhance each other's authority by referring to one another's decisions. The ECHR (or individual judges writing for it) periodically refers to ECJ decisions both to assert its primary authority in a case of potentially conflicting jurisdiction and to bolster its own power over national courts by referring to a similar power of the ECJ. Cases in the first category are relatively straightforward, essentially involving doctrinal interpretations designed to resolve confusion created by conflicting judicial rulings. In Funke v. France, ${ }^{214}$ for example, the ECHR held that France had violated the applicant's right to remain silent and to avoid self-incrimination by imposing monetary sanctions on him for failing to produce certain documents. The ECHR's decision was in direct conflict with a ruling of the $\mathrm{ECJ}$ four years earlier. ${ }^{215}$

213. See JON Elster, NUTS AND BOLTS fOR tht SOCIAL SCIENCES 13 (1989) (descnbing methodological individualısm).

214. 256-A Eur. Ct. H.R. (ser. A) at 22 (1993)

215. See Case 374/87, Orkem A.S. v. Commission. 1989 ECR 3283, see also Walter B J van Overbeek, The Right To Reman Silent in Compenton Imeshgations The Funke Deciston of the European 
Cases in the second category are more interesting. In Fischer $v$. Austria, ${ }^{216}$ for instance, Judge Martens commented on the influence of ECJ case law in convincing member states of the European Community that state administrative organs should be accountable to the judiciary, a power being exercised by the ECHR in the case before it. ${ }^{217}$ Similarly, in Konig $v$. Federal Republic of Germany, ${ }^{218}$ Judge Matscher justified the ECHR's interpretation of a provision of the Convention by reference to the principles of treaty interpretation developed by the ECJ in a case decided two years earlier. ${ }^{219}$ Both Fischer and Konig depict the two tribunals as pursuing parallel trajectories, establishing the principle of supranational review and developing a common body of rules or doctrines to guide the exercise of their newfound powers.

Cases in which the ECJ cites ECHR decisions result from the particularities of the ECJ's own human rights jurisprudence, based on constitutional traditions common to the fifteen European Union member states and international human rights treaties to which they are signatories, particularly the European Convention on Human Rights. ${ }^{220}$ It thus periodically falls to the ECJ to use both the provisions of the Convention and interpretations of those provisions by the ECHR as a starting point for its own analysis of the nature and extent of specific human rights provisions under Community law. ${ }^{221}$ Even when the Court itself does not directly reference ECHR decisions, it often hears argument invoking these decisions either by its Advocate General or by the parties. ${ }^{222}$

In other cases, parties before the ECJ, as well as the Advocate General, have relied on ECHR decisions as evidence of emerging international or

Court of Human Rights Makes Revision of the ECJ's Case Law Necessary, 15 EUR. CoMP. L. REv. 127 (1994).

216. 312 Eur. Ct. H.R. (ser. A) (1995).

217. See $i d$. at 27 n.5 (separate opinion of Martens, J.).

218. 27 Eur. Ct. H.R. (ser. A) (1978).

219. See id. at 46 (separate opinion of Matscher, J.) (citing Case 29/76, Lufttransportunternehmen GMbH v. Eurocontrol, 1976 E.C.R. 1541).

220. See, e.g., Case 4/73, Nold v. Commission, 1974 E.C.R. 491.

221. See, e.g., Cases 46/87 \& 227/88, Hoechst AG v. Commission, 1989 E.C.R. 2859, 2924 (explaining that "there is no case law of the [ECHR] on [the] subject" of interpreting Article 8(1) of the Convention); Case 152/84, Marshall v. Southhampton \& S.-W. Hampshire Area Health Auth., 1986 E.C.R. 723, 743-44 (citing the ECHR for the proposition that fundamental human rights, incorporated as part of the general principles of Community law, "must be given a wide interpretation").

This intertwining of case law becomes even more complex when partics argue that a particular action of a European Community organ is itself a violation of the Convention. See Cases 209 to 215 \& $218 / 78$. Heintz van Landewyck S.a.r.l. v. Commission, 1980 E.C.R. 3125 (ruling on a claim that an action of the Commission of the Community violated Article 6(1) of the Convention and referencing an ECHR decision interpreting the Article).

222. See, e.g., Case 326/88, Anklagemyndigheden v. Hansen \& Son I/S, 1990 E.C.R. 2911 (opinion of the Advocate General) (referencing the ECHR's interpretation of Article $6(2)$ of the Convention as supporting a presumption of innocence until proven guilty); Cases 175/86 \& 209/86, M v. Council, 1988 E.C.R. 1891, 1896 (referencing the ECHR's interpretation of Article 6 of the Convention in the pleadings). 
regional consensus ${ }^{223}$ and as a general source of ideas and analysis. ${ }^{224}$ The $\mathrm{ECJ}$ has only infrequently cited the referenced decisions directly in its own opinions, but has presumably taken such pleadings and argumentation into account in reaching its decisions. It should be noted as well that not all of these pleadings ask the Court to "follow" the ECHR; they sometimes invoke an ECHR position only to distinguish it or to justify a different line of reasoning or outcome. ${ }^{225}$

Each tribunal's willingness to refer to the other's rulings has interesting implications for enhancing their influence and effectiveness generally. Judge Thijmen Koopmans of the ECJ speculates that the Cour "has become one of the major sources of legal innovation in Europe not only because of its position as the Community's judicial institution, but also because of the intellectual strength of its comparative methods." ${ }^{226}$ It is the Cour's ability to canvass different national and supranational approaches to a particular legal problem, he argues, that convinces national courts to pay attention to its rulings. ${ }^{227}$ The underlying premise here assumes the intrinsic value of widespread and diverse input in a deliberative process: Two minds are better than one, and fifteen minds, particularly minds from different perspectives and cultures, are better than two.

Koopmans's justification of the ECJ's comparative method focuses on the enhanced quality of decisions resulting from the likelihood that cross-national research will either turn up potential errors in and problems with a particular legal solution or open the door to innovation based on a wider range of potential models. ${ }^{228}$ Of course, comparative canvassing of precedents from national courts serves these same ends. ${ }^{229}$ But the citation of a coequal

223. See, e.g., Case 155/79, AM \& S Eur. Lid. v. Commission, 1982 E C R 1575, 1600 (arguing that the decisions of the ECHR support the view that legal privilege is a practical guaranice of fundamental individual rights).

224. See, e.g., Case 3479, Regina v. Henn, 1979 E C R 3795, 3821 (optnon of the Advociste General) (relying on the ECHR judgment in Handyside v: Unted Kungdom. 24 Eur C H R (ser A) (1979), to interpret Article 36 of the Treaty of Rome).

225. See, e.g., Case 112/83, Societe des Produits de Maus SA y Admintsrauon Des Douanes et Druts Indirects, 1985 E.C.R. 719 (considering the plainuff's rejcetion of an analogy to an ECHR deciston). Case $61 / 77$, Commission v. Ireland, 1978 E.C.R. 417, 464 (opinion of the Advocate General) (objecung to the Irish government's effor to invoke ECHR case law due to "the different wording used" in the Cunvention and the Treaty of Rome).

226. Koopmans, supra note 188, at 505.

227. See id.

228. Some criticize Protocol No. Il to the Convention-which abolishes the Iwo-stuge provedure providing for review of cases first by the Commission and only then by the ECHR-lur destruying "the possibility of mutual criticism which now exists between the Commission and the Cuurt " Schermers, supra note 158 , at 560 . Judge Schermers fears that "the loss of this mulual education will creste the nsk that the new Court will accentuate its own mistakes." Id.

229. In this respect, both the ECHR and the ECJ can also be seen ats engaging in what might be termed an "intermediated dialogue," in which the supranational tnbunal acts as a broker for communtiation among national courts of Europe. As noted by Polakiewicz and Jacob-Folizer, "pnniples like the proportionality test that have been developed in cenaun national legal orders are tiken up by the IECHRI and later accepted in other countrics as pan of a common European standard " Pulakicwitz \& JacobFoltzer, supra note 91 , at 66 . The authors charactenze this process as "the beginning of a dialogue between 
supranational court fulfills a distinct and equally important function, that of mutual legitimation of the very act of adjudication above the level of the nation-state. By citing to other supranational decisions as authoritative and worthy of consideration, the citing court acknowledges its engagement in a common enterprise with the cited court, an acknowledgment that implies the possibility of an objectively "better" legal solution to a common legal problem and of some degree of cultural cross-communication.

Such recognition does not deny the necessity of tailoring solutions to the specific cultural and political requirements of a particular legal system; on the contrary, a number of the examples cited above refer to a case from a parallel tribunal only to distinguish it. Nevertheless, acknowledged engagement in a common enterprise at least partially independent of particular jurisdictional and substantive instruments, cultures, and countries is the essence of the idea (and ideal) of a global "community of law," which we discuss in Part V. For the moment, however, it is striking and significant that two of the world's most effective supranational tribunals appear to benefit more from solidarity than insularity.

\section{f. Form of Opinions}

A final point raised by observers of both the ECJ and the ECHR in assessing the tribunals' effectiveness is the forms of their opinions. The principal issue with respect to form is whether the opinion should be written as if the judgment were unanimous or if dissents and concurring opinions should be allowed. Opinions differ substantially on this question as do the two courts themselves: The ECJ disallows individual concurring and dissenting opinions, whereas the ECHR permits them. ${ }^{230}$

In the ECJ context, the Court itself and a number of observers assume that the Court benefits considerably from its no-dissent rule. This is so for a number of reasons. First, the rule allows the Court to speak as the uniform and

these different jurisdictions." Id. at 142. The ECJ's periodic adoption of a particular national approach or standard as an appropriate rule for the European Union as a whole may have a similar impact. Further, awareness of the dynamic by which national law can become European law and then move into other national legal systems may encourage input from a number of national courts desiring to influence the evolution of European law in a direction more favorable to their national traditions. See Slaughter, supra note 146 , at 114 n.46.

230. It is possible, of course, for the states party to the treaty establishing a tribunal to prohibit jurists from filing individual opinions. To that extent, the form of opinions may properly be included as a fuctor within the control of states. See supra Subsection III.B.1. Nevertheless, in the case of the ECJ, the treaty does not prohibit individual opinions; it is the Court itself that has imposed a rule of unanimity. See Rules of Procedure of the Coun of Justice, Rule 27.5, 1974 O.J. (L 350) 1, reprinted in ENCYCLOPEDIA OF EUROPEAN COMMUNITY LAW at B8108 (1992). Similarly, Article 51(2) of the Convention, supra note 2. 213 U.N.T.S. at 248, and Aricle 45(2) of Protocol No. 11, supra note 93, expressly permit (but of course do not require) individual opinions, leaving the issue to individual jurists. We have thus included form of opinions as within the power of the tribunals themselves. 
quasi-mystical "voice of the law": 231 Judges, originally from six national traditions and now from fifteen, merge their differences and speak as one. ${ }^{332}$ Second, unanimous decisions have insulated individual judges from political pressure from their governments. ${ }^{233}$ Third, as Judge David Edward observes, the unanimous judgment tradition fosters the relative speed of ECJ decisions, at least in the sense of "avoiding further serious delay." streamline the process by excluding dissenting judges from the Cour's deliberations after an initial vote on the outcome "would seriously affect, if not destroy, the collegiate character of the Cour and its decision-making process." ${ }^{.235}$

On the other hand, voices have recently been raised criticizing the impact of the unanimous-decision rule on the reasoning of the Courts decisions. The need to reach a uniform result, these commentators argue, frequently produces strategic ambiguity, awkward transitions, and lowest common denominator statements of the law. ${ }^{236}$ These authors thus highlight a tension between uniform authority and the quality of legal reasoning.

Commentary on the ECHR is in greater agreement on the value of multiple opinions. Merrills emphasizes that the ECHR depends on the support of governments, "who must be satisfied that in accepting its obligations . . they are subscribing to a system whose object and effect are the protection of rights.

231. This view lies at the core of a more general phulosophy of legalism. pertups best summan in an oft-quoted passage from Marun Shapiro (alihough he formulates $t$ only as a prelude to a poinled critiq̨ue):

[T] he Community [is presented] as a junstic idea, the written constitution as a sacred text, the professional commentary as a legal truth; the case law as the inevitable working out of the correct implications of the constitutional text; and the constututional coun as the disembexied voice of right reason and constitutional teleology

Martin Shapiro, Comparative Law and Comparative Polhtcs. 53 S CAL L REV 537. 538 (1980) Mure pragmatically, Derrick Wyatt and Alan Dashwood observe that, "دs a young judicial institution. the court needed to build up its authority by presenting a unted front to the world "DFkRJCK WYATT \& ALAN DASHWOOD, EUROPEAN COMMUNITY LAW 109 (1993)

232. See Everling, supra note 188, at 1295 Compare this with the decision of the U S Supreme Cuurt to hand down a unanimous opmion aganst President Nixon in Unied Stases i Niton. +18 L S 683 (1974), a decision echoing the Cour's earlier choice of a single opinion in Cooper a Aaron. 356 ('S 1 (1958). which enforced a desegregation ruling issued in the face of strong locial resistance See Bos Wouvwakb \& SCOTT ARMSTRONG, THE BRETHREN: INSIDE THE SUPRENt. COURT 295-96 (1979)

233. See WYATT \& DASHWOOD, supra note 231, at 109 TC Hartley makes the same pount Because of the unanimous opinton, "it is impossible to accuse a judge of being insulficiently sensiluse to national interests or of having "let his government down', no one oulsude the Cuun can eser know whether he vigorously defended the position adopted by his own couniry or was in the forefirunt of thuse alvocating

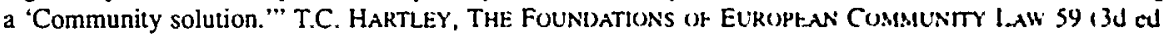
1994).

234. David Edward, How the Cours of Justice Works. 20 Euk L Rrv 539.557 (1995)

235. Id.

236. In 1995, the United Kingdom proposed that ECJ judges be permilied to publish dissenting opinions but ultimately withdrew its suggestion See John Palmer. Bristsh Drop Arrack on EU Court. GUARDIAN (Manchester), Oct. 28, 1995, aralable in 1995 WL 99480\%0, see also Frances Gibb. s/Ps Urge Major To Restrict Powers of European Court. TMt:S (London). OAt 20. 1995. an anlable in 19)S WL 7705621. Several commentators note that the lack of dissenting opinions mules at diflicult to analy ace the Court's opinions and to choose those litgation strategies most likely to persuate the ECJ judges Set. e $g$. Andrew Watson, The European Court Afier Factoname. 71 INT'L COM LITIG 19. 19.21 (1995/1996) 
and not national humiliation. ${ }^{237}$ In this context, he argues, separate opinions are "especially important" in marshalling government support. ${ }^{238}$ Those separate opinions that review issues omitted from the judgment or that reassert a particular government's position "can do much to maintain the correct perspective."239 Ost concurs, noting the particular value of separate opinions as part of his more general theory that the persuasive value of a judgment "derives from its intrinsic rationality."240

It is possible to reconcile these two views if we note that the ECJ talks primarily to national courts, whereas the ECHR depends more directly on the reactions of national bureaucrats and politicians. Addressing an audience of national judges, themselves accustomed to handing down "the law," the ECJ may be right in its calculation that unanimity enhances authority. In addition, this audience was initially relatively small and uniform-judges from six civil law countries at the core of Western Europe. The ECHR, by contrast, has found itself seeking to persuade government officials from fifteen countries, adding the Austrian, British, Irish, Scandinavian, Greek, and Turkish legal systems to the original mix. ${ }^{241}$ In this context, evidence that a number of judges could reach the same conclusion, albeit on different grounds, and that contrary arguments had been thoroughly ventilated, as demonstrated by dissenting opinions, could well enhance persuasive power. ${ }^{242}$ Indeed, as the number of countries subject to the jurisdiction of the ECJ grows, pressure has mounted on the Court to drop the unanimity rule..$^{243}$

\section{Factors Often Beyond the Control of States or Judges}

The value of a checklist of effective supranational adjudication is not only as an analytical tool, but also as a set of practical recommendations for states and judges. The experiences of the ECJ and the ECHR, however, suggest that not all factors contributing to effective supranational adjudication are within these actors' control. Judges may be presented with disputes that they cannot resolve. The states under their jurisdiction may ultimately be impermeable to supranational penetration due to underlying domestic political conditions. The cultural diversity of both judges and states may be too great to bridge.

Were any of these factors determinative, the rest of the checklist would be futile. It is more likely, however, that while these factors may limit how far

237. MERRILLS, supra note 77 , at 36 .

238. Id.

239. Id.

240. Ost, supra note 194, at 284.

241. See Robertson \& MERRILLS, supra note 81 , at 320 n.5.

242. The range of concurrence and dissent in any one case should not be exaggerated, however. The majority of the ECHR's cases are heard in chambers of nine judges. Robertson and Merrills note that only about one case in three is heard by the plenary court. See ROBERTSON \& MERRILLS, supra note 81, at 299.

243. See The Laws of Canute, ECONOMIST, Oct. 7, 1995, at 62. 
along the spectrum toward fully effective supranational adjudication a particular tribunal is likely to move, there remains considerable room to improve. Moreover, these factors typically receive far less attention from scholars and commentators than those listed above; the causal mechanisms by which they affect supranational adjudication remain relatively unchared. It is thus also more difficult even to estimate the relative importance of the factors we identify; they are very likely to overlap and even to collapse onto one another. Our ordering reflects analytical convenience as much as relative weight. Finally, we supplement the observations of scholars and commentators on the ECJ and the ECHR with our own analysis based on our earlier definition of supranational adjudication.

\section{a. Nature of Violations}

A principal factor that has contributed to the success of the European human rights system is the limited nature of complaints brought before the ECHR. Menno Kamminga directly attributes the success of the ECHR to the minor and unintentional nature of most violations found under the Convention, which requires few concessions from the offending state. ${ }^{2+4}$ Practically every case brought to the European Commission of Human Rights concerns either maladministration or the types of conflicts of interests prevalent in any complex society. ${ }^{245}$ Indeed, Torkel Opsahl draws a contrast between the kinds of cases typically heard by the ECHR and those often submilted to the U.N. Human Rights Committee by noting the difference in the percentage of cases declared admissible - "almost 50 percent [in the U.N. system] as against less than 3 percent [in the European system]." difference to the "serious facts of many cases [going to the UNHRC]."247

A sad paradox results. At least in the human rights arena, international human rights regimes and the supranational tribunals that enforce them have been most effective in the states that arguably need them least: those whose officials commit relatively few, minor, and discrete human rights violations. ${ }^{248}$ As Paul Sieghart points out, the administrative and legislative organs of the states parties in Europe have often made changes in direct response to the "substantial and extensive jurisprudence" of the European

244. See Menno T. Kamminga, Is the European Conchron on Human Rights Sufficarnt, Equipped To Cope with Gross and Systematic Violations? 12 NETH Q HUM RTS 153.153.54 (1944)

245. See A.H. RobertSON \& J.H. MERRILLS, HUMAN RIGITS IN THE Wukt.1) 62 (3J al 19S9) That such cases exist at all demonstrates that human righis are not merely an assue for the nundemoxistuc world See id.

246. Opsahl, supra note 17 , al 423

247. Id.

248. See Moravcsik, supra note 9. at 178-80 These breaches ste unquestunably grave trum the perspective of their victims and the cilizenry of the states involved. but they nevertheless pule in light of the entire spectrum of human rights abuses across states 
Commission of Human Rights and the ECHR. ${ }^{249}$ Even within Europe, however, the states most likely to respond to the ECHR are the states with the least to hide. Both the Commission and the ECHR, for example, were relatively powerless in the face of systematic human rights violations in Greece during the military dictatorship in the early 1970s; indeed, Greece ultimately withdrew from the Convention. 250

A related phenomenon is at work concerning the ECJ, although commentators have not discussed it in precisely the same terms. As policymakers and scholars became increasingly aware of the power of the ECJ in the late 1980s and early 1990s, many gave it credit for devising and implementing the policy of "mutual recognition." Under this policy, European Union member states recognized each other's production standards and other trade-related regulation, thereby providing an alternative to the slow and difficult process of harmonization around a unitary standard. ${ }^{251}$ In fact, as two political scientists demonstrate, the ECJ's role was much more modest; although it formulated the concept of mutual recognition in an important decision, large-scale policy change depended on subsequent action by the European Union Commission. ${ }^{252}$ This debate over the role of the ECJ is strikingly similar to the debate about the impact of the U.S. Supreme Court's decision in Brown v. Board of Education; ${ }^{253}$ in both cases, political scientists (and some lawyers) have sought to temper those (mostly lawyers) who are prone to overestimate the power of courts.

For present purposes, however, the story has a different moral. If courts are relatively ineffective at generating the kind of wholesale policy change necessary to respond to systemic problems, it follows that courts faced only with those kinds of problems are likely to be less effective than those charged with policing modest deviations from a generally settled norm or modifying a particular rule or set of rules incrementally. The scope and gravity of the disputes presented to courts is partially within the control of courts themselves and partially within the control of the states that establish them. Doctrines of

249. SIEGHART, supra note 159 , at 27.

250. Greece signed the Convention in 1953. After the installation of a military dictatorship, the country withdrew from the Convention in 1970. It rejoined the Convention in 1974. See RoBERTSON \& MERRILLS, supra note 81 , at 279.

251. See David Vogel, Trading UP $32-35$ (1995); Jacques Pelkmans \& Jeanne-May Sun, Towards a European Community Regulatory Strategy: Lessons from "Leaming-by-Doing," in ORGANIZATION POR ECON. CO-OPERATION AND DEV., REGULATORY CO-OPERATION FOR AN INTERDEPENDENT WORLD 179, 181 (1995); Michel Waelbroeck, The Role of the Court of Justice in the Implementation of the Single European Act, 11 Mich. J. INT'L L. 671, 676 (1990).

252. See Karen Alter \& Sophie Meunier-Aitsahalia, Judicial Politics in the European Communtry: European Integration and the Pathbreaking Cassis de Dijon Decision, 26 COMP. POL. STUD. 535, 541-43, 554-55 (1994) (discussing Case 120/78, Rewe-Zentral v. Bundesmonopolwaltung fur Branntwein, 1979 E.C.R. 649); R. Barents, New Developments in Measures Having Equivalent Effects, 18 CoMmON MKT. L. REV. 271 (1981).

253. 347 U.S. 483 (1954). For a review of this debate and a strong argument that the Supreme Court is incapable of securing social change, see GERALD N. ROSENBERG, THE HOLlOW HOPE: CAN CouRTS BRING About Social Change? (1991). 
standing and justiciability can limit the number and identity of parties permitted to appear before the court and can ensure that a dispute is ready and appropriate for judicial decision. Jurisdictional grants such as the U.S. constitutional requirement that courts hear only "cases or controversies" rather than rendering advisory opinions on pure questions of lawes: can further narrow and shape a particular docket. But in the end, the isolated or systemic nature of the alleged violations of law that a particular cour is asked to remedy depends a great deal on the nature of the states themselves that are subject to that court's jurisdiction. As the example of Greece demonstrates, even states who choose their fellow signatories to an international agreement very carefully cannot control for political stability over time. In such circumstances, even a supranational tribunal that has been relatively effective may suddenly find itself adrift and increasingly irrelevant.

\section{b. Autonomous Domestic Institutions Committed to the Rule of Law and Responsive to Citizen Interests}

The European experience of supranational adjudication is the experience of two supranational tribunals operating within a community of liberal democracies with strong domestic commitments to the rule of law. This dimension of the European experience provides the subtext for much of the analysis of factors discussed in this section, such as the nature of violations or cultural homogeneity. More recently, however, a number of scholars have begun to tackle directly the relationship between liberal democracy and international dispute resolution.

The burgeoning literature on the "democratic peace," seeking to explain why liberal democracies rarely if ever go to war with one another, has spurred scholars to explore other ways in which attributes of a domestic regime-type affect international behavior. ${ }^{255}$ of particular interest here are hypotheses, as yet unproved, concerning the positive impact of liberal democracy on compliance with international commitments, including the judgments of international and supranational tribunals. ${ }^{256}$ As defined in this literature, "liberal democracy" combines representative government with a commitment

254. See U.S. CONST. an. III, § 2

255. The relative transparency of democratuc poltics, for instunce. is alleged lo hase a pusttwe impact on the credibility of commitments entered into by literal demecracies See Lon Fisler Damrosch. Constitutional Control over War Powers: A Common Core of Accoumabulin in lemecratu Sactelurs'. 50 U. MLAMI L. REV. 181, 183 (1995): Charles Lipson. The Promise ut Peate Among Liberal Dernuxisties (1995) (unpublished manuscript, on file with authors)

256. See William J. Dixon, Democracy and the Masagement of luternanonal Canfitht, $37 \mathrm{~J}$ (ONFLict RESOL. 1, 42 (1993) (argung that democratic stales are more likely than others to resulse or ameliotale their international disputes by arrangements secured with the assistance of thud purties), Gregory Raymond.

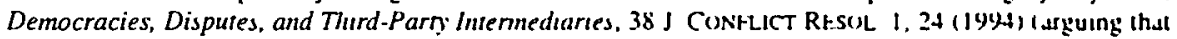
pairs of democratic states are more likely than dyads meluding one or more nondemix aties to preter disagreement to binding third party settement); Slughter, Internamonal Las. supra nule 55. at 532 
to the rule of law, itself defined to include both an independent judiciary and protection of basic civil and political rights. ${ }^{257}$ The specific hypotheses positing a causal connection between liberal democracy and compliance with international obligations generally focus either on a rule-of-law mechanism or on a democratic politics mechanism. ${ }^{258}$

The rule-of-law approaches rest on the basic intuition that states committed to the rule of law domestically will be more law-abiding in the international realm, through the projection or transferral of their domestic habits. Accustomed to self-imposed constitutional constraints at home, constraints enforced by an independent judiciary, they are more likely to accept the constraints of international law as enforced by an international or supranational tribunal. ${ }^{259}$ This equation is too simple. On the one hand, states without a domestic tradition of respect for the rule of law and the concomitant recognition of the importance of an independent judiciary are unlikely to respect the judgments of an international tribunal. In many former communist states, law was regarded primarily as a tool of the bourgeoisie; in many former colonies, law has been primarily an instrument of state oppression. On the other hand, states with the strongest traditions of domestic rule of law and independent judiciaries may also conclude that they have no need for international supervision-that, on the contrary, receptivity to international law, including the judgments of a supranational tribunal, might even weaken the domestic system. ${ }^{260}$ The frequent hostility of U.S. courts to enforcement of

257. In his pioneering work on the "democratic peace," Michael Doyle actually examines conflict between what he defines as "liberal states": states with some form of representative democracy, a market economy based on private property rights, juridical equality, and constitutional protections of civil and political rights. See Doyle, Foreign Affairs, supra note 6, at 207-08; see also Slaughter, International Law, supra note 55, at 511 ("Liberal democracy ... denotes some form of representative government secured by the separation of powers, constitutional guarantees of civil and political rights, juridical equality, and a functioning judicial system dedicated to the rule of law.").

258. We borrow this typology from Beth Simmons, who is undertaking an important study of the sources of compliance with the judgments of international and supranational tribunals. The first phase of her project focuses on compliance with the rulings of interstate arbitral tribunals in territorial disputes in Latin America-tribunals that we would identify as international rather than supranational tribunals. See Beth Simmons, Capacity, Commitment, and Compliance: International Law and the Settlement of Territorial Disputes (June 1997) (unpublished manuscript, on file with authors). Her work, however, will make a major contribution toward proving or disproving the various hypotheses discussed in this section. A similar distinction between types of explanations in the democratic peace literature more gencrally can be found

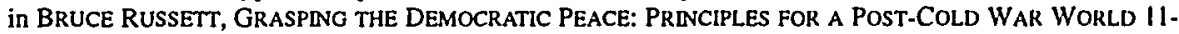
23 (1993), which contrasts "normative" with "structural" explanations for the democratic peace.

259. See Roger FISHER, IMPROVING COMPLIANCE WITH INTERNATIONAL LAW 30 (1981) (arguing that constraints imposed by international law resemble constitutional constraints in that both are metanorms that rest on shared normative acceptance); Charles A. Kupchan \& Clifford A. Kupchan, Concerts, Collective Security, and the Future of Europe, 16 INT'L SECURITY 114, 115-16 (1991) ("[S]tates willing to submit to the rule of law and civil society domestically are more likely to submit to their analogues internationally."); Raymond, supra note 256, at 24.

260. These attitudes are one explanation for the historic reluctance of U.S. courts to recognize international law. Another explanation notes that the fierce opposition to many international human rights instruments was fueled largely by southern fears that these instruments would be used to advance civil rights for African Americans. In the early 1950s, Senator Howard Bricker led a campaign to amend the Constitution so as to restrain the federal government's treaty-making power. Bricker and his supporters 
international law over domestic law can be explained in part on this basis, as can variation in the mode and timing of acceptance of European Community law by European national courts. ${ }^{261}$

The democracy-based hypotheses, by contrast, focus on the power of international legal obligations to mobilize domestic interest groups, who in turn pressure democratic governments to comply. ${ }^{262}$ The underlying assumption is that individuals and interest groups will either invoke the rulings of an international tribunal as support for a position they independently espouse or that they will simply hold their governments to account for failure to comply with international law. We make similar arguments about the role of private parties in pressuring government institutions to comply with the rulings of a supranational tribunal. These accounts, however, assume interest group pressure on a unitary state, omitting both the complex interactions of distinct domestic government institutions and the motives of those institutions either to respond to private pressure or independently to push for compliance. Further, they do not distinguish between compliance with international law generally and compliance with international or supranational judgments; thus they cannot take account of the specific dynamics between a supranational tribunal and domestic government institutions.

Drawing on this literature and on our analysis of the experiences of the ECJ and the ECHR, we conclude that the existence (in states subject to the jurisdiction of a supranational tribunal) of domestic government institutions committed to the rule of law, responsive to the claims of individual citizens, and able to formulate and pursue their interests independently from other government institutions, is a strongly favorable precondition for effective

feared that the ability of treaties to be self-exccuting, coupled with Justuce Holmes's dictum in w/essusurs v. Holland, 252 U.S. 416,432 (1920), implying that treaties are not bound by Article 1 limitations on the scope of lawmaking power, threatened U.S. sovereignty See Thomas MI Fraser \& Mtichatl J GLENNON, Foreign RELATIONS AND NaTIONAL SECURITY LAW 297 (2d ad 1993) A number of scholars entered the debate on the propriety of such an amendment. Compare. 8 . George Finch. Thie Need To Restrain the Treaty-Making Pos'er of the U.S. Withm Conshtuhonal Lumts. 48 AM J INT'L L 57 (1954) (arguing for the enactment of the proposed amendment to the Cunstitution). wh John B Whillon \& J Edward Fowler, Bricker Amendment-Fallacies and Dangers. 48 AM J INT'L L 23 (195-9) (opposing the ratification of the amendment).

261. Europe's highest national courts often fought the hardesi aganst atecplanie of European Community law supremacy, in pan to defend their instutunonal prerogatives, but also, particularly in Germany and Italy, to safeguard their role in ensuring a domestuc rule of law under their post-war constitutions. See, e.g., KOKOTT, supra note 129. at 8.9 (describing the resistance of the German Constitutional Court to the supremacy of European Community law until the ECJ incorporated satusfactory human rights guarantees). French courts resisted acceptung European Communty law to the extent that they saw it as an invitation to engage in judicial review, thereby undermining a pillar of the French legal system designed to ensure that the law as applied expressed the will of the people rather than the whim of the judges. See Karen Alter, The Making of a Rule of Liw in Europe. The European Coun and the Natsona! Judiciaries 191-93 (1996) (unpublished Ph.D. dissertation. Massachusets Inst of Tech) (on filc with authors).

262. See Fisher, supra note 259, al 134; OsCar Schachter. INTERNATIONAL LAW IN THEORY AND PRACTICE 7 (1991). 
supranational adjudication. It may even be a necessary (although not sufficient) condition for maximally effective supranational adjudication.

This precondition is inherent in our definition of effective supranational adjudication as the ability of a supranational tribunal to compel compliance with its judgments by convincing domestic government institutions, either directly or through pressure from private parties, to use their power on the tribunal's behalf. A supranational tribunal can invoke the power of law and the interests of ordinary citizens, but these appeals will be far less persuasive if they do not resonate with domestic political values. Domestic governments that recognize little obligation to protect or represent their citizens will be less subject to popular pressure mobilized, or at least reinforced, by a supranational judgment. Political regimes in which the rule of law is a paper promise will be less likely to produce institutions or individuals willing to privilege supranational legal rules over claims of national interest. And monolithic governments, in which power is effectively exercised only by the executive, simply offer no opportunities for a supranational tribunal to penetrate the state in the first place. Conversely, however, government institutions committed to both the rule of law and separation of powers not only as ends in themselves, but also as bulwarks of individual rights and liberties in systems where the individuals themselves are ultimately sovereign, are primed to be the most receptive to the tools that a supranational tribunal has at its disposal. The presence of those institutions has been an important dimension of the European experience.

Notwithstanding the European experience, however, the link between liberal democracy and effective supranational adjudication is complex and contingent, particularly at the margins. Two further caveats are thus in order. First, as just noted, even if the presence of autonomous domestic institutions committed to the rule of law and responsive to individual citizens is a necessary condition for maximally effective supranational adjudication, it is not sufficient. The story still lacks a motive: a specific incentive for a specific domestic government institution to make common cause with a supranational tribunal against its fellow government institutions. Identifying such incentives requires a detailed understanding of institutional interests and patterns of competition in specific countries. ${ }^{263}$ Variation regarding the presence or absence and strength or weakness of these incentives also ensures that the narrative of effective supranational adjudication is not a teleology. To the

263. Karen Alter has made this point persuasively with regard to the incentives facing national courts in European Union member states to forge a partnership with the ECJ. She develops a "judicial competition" model that helps explain the motives of some courts in some countries, which must be modified country by country to take account of the structure and culture of national judicial systems. See Alter, supra note 261, at 78-93. Other analyses emphasizing the importance of judicial politics in the relationship between the ECJ and European national courts are MARY L. VOLCANSEK, JUDICIAL POLITICS IN EUROPE 245-67 (1986); and J. Golub, Politics of Judicial Discretion: Rethinking the Relationship Between National Courts and the ECJ, 9 W. EUR. POL. 360, 377-80 (1996). 
contrary, finding and recruiting domestic institutions as partners is likely to be a slow and sticky process.

Second, even in a political system that is otherwise comupt or oppressive, it is possible that a particular government institution-a cour or administrative agency or even a legislative body - will choose to forge a relationship with a supranational tribunal as an ally in a domestic political battle against corruption or oppression. Whether such an alliance would be efficacious depends on the nuances and sensitivities of local politics, but the larger point is that participation in the "community of law" constructed by a supranational tribunal is open not only to countries but also to individual political and legal institutions, regardless of how the state of which they are a par is categorized or labeled. The disaggregation of the state that underlies our distinction between supranational and international adjudication also disaggregates a state's unitary political identity as "democratic" or "undemocratic," "liberal" or "illiberal." Nondemocracies may have democratic impulses, embodied in specific institutions; illiberal states may have strong liberal leanings. The same ability to penetrate the surface of the state that gives supranational tribunals their potential power also creates opportunities for them to operate beyond the club of western liberal democracies.

\section{c. Relative Cultural and Political Homogeneity of States Subject to a Supranational Tribunal}

Many observers of the ECJ, the ECHR, and the Inter-American system have contrasted the relative homogeneity of the states paricipating in these systems with the diversity of universal regimes such as the International Covenant on Civil and Political Rights. ${ }^{264}$ Merrills, for example, contrasts the ECHR, with members drawn from only one geographic region with common, although not identical, legal traditions, with the International Court of Justice (ICJ), "where the absence of common cultural reference points and the diverse issues for adjudication often makes accommodation extremely difficult."26s Nisuke Ando ties the competence of both the ECHR and the Inter-American Court of Human Rights to issue binding decisions to the shared strong convictions of all the states party to their founding conventions, convictions "nurtured by a long tradition of common history, religion, culture and human values." 266 He hypothesizes that it is premature to expect states not sharing

264. Covenant, supra note 15.

265. MERRILLS, supra note 77, at 24. Regarding the ECHR, Micrnlls notes that the "fatet that the [ECHR's] judges share a common outlook and are engaged on a single enterpnse dues not mean that they will always agree on what to do and how to do it. It does, however, appreciably nurrow the scope for disagreement." Id. at 23; see also SIEGHART, supra note 159. at 26-27 (reisoning that states "within the same geographical region, shanng a common history and cultural tradituon." will more casily redech agreement on the substance of human rights provisions).

266. Ando, supra note 20, at 171-72. 
such a common conviction and tradition to authorize an international tribunal to render binding decisions. ${ }^{267}$

In some cases, "cultural and political homogeneity" may be code for liberal democracy in the sense that the commentator does not actually believe that any group of culturally and politically homogeneous states would support a supranational tribunal. In other cases, however, commentators appear to be pointing to an additional attribute of the states subject to the jurisdiction of a supranational tribunal that may help or hamper the tribunal's ability to communicate effectively with the subjects of its judgments and to build trust in reaching out to specific government institutions. Cultural and political homogeneity is to some extent within the control of the states choosing to establish a supranational tribunal. Yet homogeneity is not a constant. As the experience of the Council of Europe's expanding membership into Eastern Europe and former Soviet states demonstrates, even nations with very different social and political histories may seek to join a treaty regime with a dynamic and powerful supranational court. ${ }^{268}$ Moreover, states seeking to draft "universal" agreements such as the Covenant and other U.N.-based human rights treaties are themselves looking for a common glue to bind many diverse cultures and political systems together.

\section{Reviewing the Checklist}

The foregoing analysis condenses and integrates the extensive writings of judges, lawyers, and commentators, together with our own observations, into a checklist of factors that covary with and are claimed to contribute to effective supranational adjudication in Europe. To review, the factors cluster into three categories: (1) factors within the control of states party to the treaty regime (the composition of the tribunal, the caseload and functional capacity of the court, independent factfinding capacity, and the legal status of treaties and the tribunal's decisions); (2) factors within the control of the supranational tribunal itself (its awareness of audience, neutrality and demonstrated autonomy from political interests, incrementalist style of decisionmaking, the quality of its legal reasoning, its dialogue with other supranational tribunals, and the form of its opinions); and (3) factors often beyond the control of both states and jurists (the nature of the violations to be monitored by the tribunal, autonomous domestic institutions committed to the rule of law, and the cultural and political homogeneity of the states subject to a supranational tribunal).

Generating anything as concrete as a checklist to measure a phenomenon as complex as supranational adjudication inevitably requires making many choices, some of which are bound to invite disagreement. Many will tell the

267. See id.

268. See Two Nations Join Panel for Rights in Europe, N.Y. TmEs, Nov. 10, 1995, at A10. 
story of Europe differently and draw different conclusions. An equally important question is the applicability of the checklist to supranational tribunals outside Europe. The factors in the checklist are not culturally or geographically specific; they require political preconditions that are more concentrated in the West but that are themselves the product of a universalist political ideology and exist in states throughout the world.

Most importantly, the European experience challenges us to transcend the traditional framework of "state versus tribunal," summoning an image of a confrontation between two discrete entities in which the outcome depends upon whether the state defines its (unitary) national interest to include compliance with international law. The ECJ and the ECHR have succeeded in becoming effective supranational tribunals by looking not to states per se but to their component institutions, using the link to private parties granted them as supranational tribunals to penetrate the surface of the state. The decision concerning what effect to accord a supranational judgment is not made by a unitary government, but rather by courts, ministries, and legislative committees competing and cooperating with one another as par of the normal domestic political process. Where states actually live up to the unitary fiction due to a monolithic concentration of power or, conversely, where state institutions do not exercise enough power to establish effective public order, supranational tribunals will be stymied. In all other circumstances, however, many possibilities exist for influencing and coopting domestic institutions.

\section{APPLYING THE CHECKLIST TO THE UNITED NATIONS HUMAN RIGHTS COMMITTEE}

We began with the claim that the ECJ and the ECHR were relatively "effective" supranational tribunals, meaning that their judgments had an impact-not only on the litigants involved, but also on the larger society and on distinct government institutions-comparable to the impact of domestic courts in the states subject to their jurisdiction. The checklist then sought to isolate the specific factors that observers, practitioners, and judges of these courts have identified as contributing to their success. We do not claim that faithful adherence to all the factors on the checklist, by the states party to an agreement establishing a new tribunal and by the tribunal itself, will guarantee the effectiveness of the tribunal. To begin with, a number of important factors on the checklist remain difficult or impossible for either the states or the tribunal to control-other than by sharply limiting the number and identity of participating states. Equally important, however, is the impossibility of generating a script or an algorithm for effective adjudication. Factors such as historical contingency and personality will inevitably claim their due.

Nevertheless, the factors on the checklist highlight common elements in the experience of two important supranational tribunals, experience that may 
be supplemented by the trajectory of newer tribunals and dispute resolution bodies such as WTO and NAFTA panels, the Inter-American Court of Human Rights, or a new permanent International Criminal Court. Eschewing any magic formula, we argue that bolstering these elements is the most likely prescription for increased effectiveness.

In this part, then, we assess the experience of an international entity that has been evolving from a body that once explicitly understood itself as something other than a court into an increasingly court-like entity-the U.N. Human Rights Committee. Although the UNHRC is by no means a supranational court in the strict sense, it is significant that the Committee's recent efforts to enhance its judicial tendencies and to achieve greater compliance with its decisions have occurred contemporaneously with the emergence, to varying degrees, of numerous other checklist factors. We begin with a brief overview of the history and functions of the Committee. The remainder of this part examines the Committee's performance in light of the specific factors on the checklist from Part III.

\section{A. An Overview of the Committee}

The UNHRC engages in two principal activities in supervising states parties' compliance with the ICCPR: ${ }^{269}$ a reporting procedure and a petition procedure. Although both methods are broadly designed to ensure that states respect their treaty obligations, each procedure requires very different actions on the part of the Committee. These differences highlight the Committee's functions as both an investigative supervisory body and a quasi-judicial monitoring body. ${ }^{270}$

\section{The Reporting Process}

Article 40 of the ICCPR requires all states parties to file reports with the Committee "on the measures they have adopted which give effect to the rights recognized herein and on the progress made in the enjoyment of those rights."271 Initial reports are due within one year of the treaty's entry into force with the subsequent reports due at five year intervals thereafter. ${ }^{272}$ In general, the Committee treats initial reports as a time to establish a

269. Covenant, supra note 15.

270. See MCGoldRICK, supra note 17, at 55 (noting that the Committee's work "includes elements of judicial, quasi-judicial, administrative, investigative, inquisitorial, supervisory and conciliatory functions" and that "its nature may alter in accordance with its exercise of the various functions and roles it performs").

271. Covenant, supra note 15 , art. 40,999 U.N.T.S. at 181-82.

272. See NowaK, supra note 15 , at $548-49$. 
constructive dialogue with state representatives and devotes more detailed attention to specific human rights practices in subsequent periodic reports. ${ }^{273}$

Once a state party files its report, the Committee reviews its submission in a public session in New York or Geneva. Government representatives are invited to attend, make brief oral presentations, and respond to the Committee's substantive questions about the report. The scope of the Committee's inquiry is not limited by a state's submission and it is free to use any information available, including documents provided by nongovernmental organizations. ${ }^{274}$ After the public hearing, the Committee drafts written comments on the report and on the state pary's responses to its questions; these comments are published in its annual report to the General Assembly. ${ }^{275}$

The Committee has adopted guidelines to assist states parties in complying with their reporting obligations. Initial reports are to include two sections: an introduction describing the general legal framework of the state party, followed by an article-by-article presentation of information on (1) the legislative, administrative, or other measures in force in regard to each right; (2) restrictions or limitations imposed on the enjoyment of each right; (3) factors or difficulties affecting the enjoyment of each right; and (4) information on progress made in guaranteeing the right. ${ }^{270}$ For periodic reports, the Committee prepares a list of nonexhaustive issues that it intends to cover during the session and forwards them to the state representatives in advance of the meeting. Increasingly, these lists of issues have focused on "factors and difficulties that may be affecting implementation of the Covenant." $2 n$

The Committee does not conceive of its role in the reporting process as "contentious or inquisitory." 278 Instead, its function "is to assist State parties in fulfilling their obligations under the Covenant, to make available to them the experience the Committee has acquired in its examination of other reports and to discuss with them various issues relating to the enjoyment of the rights enshrined in the Covenant."279 Because the Committee seeks to understand the applicability of the ICCPR to a very wide field of national laws and

273. See id. at 562-63; Sandrd Coliser, Internamonal Reporning Procedures. In Guint To INTERNATIONAl HumaN RIGHTS PRACTICE 173, 180-81 (Hurst Hannum ed . 2d ad 1992)

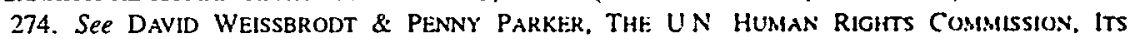
SUBCOMMISSION AND RELATED PROCEDURES 4 (1993)

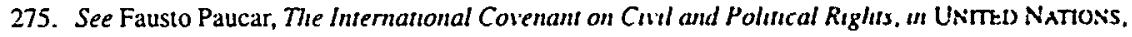
Human Rights Comm., Manual on Human Rights Reporting at 121-22, UN Doc HRPub/9III (1991).

276. See Coliver, supra note 273, at 180.

277. Work of the Human Rights Commitree Under Arucle to of the Covenum on Curl and Poluncal Rights, U.N. GAOR, Hum. Ris. Comm., 48th Sess. Supp No 40. Annex X. al 218 , UN Dox A/48/40 (1993) [hereinafter Human Rights Communee].

278. Report of the Human Rights Commuttee, UN GAOR. Hum Ris Comm. 35ih Sess. Supp No 40 , at 85 , U.N. Doc. A/35/40 (1980).

279. Human Rights Commuttee, supra note 277. al 218 
practices, and because many reports often contain inadequate information, ${ }^{280}$ the Committee has generally confined itself to questioning government representatives to obtain additional information or clarification about the implementation of the treaty. It has avoided openly criticizing individual states for failing to comply with their treaty obligations. ${ }^{281}$ The Committee, however, has repeatedly expressed its dissatisfaction with the failure of many states parties to submit initial and periodic reports in a timely fashion. ${ }^{282}$

\section{General Comments}

Instead of directly critiquing each report, the Committee addresses common problems collectively by issuing "general comments" to states parties. These comments "summarize the Committee's experience with reports and promote certain obvious goals such as co-operation between states parties, improvement of reporting, and Covenant implementation." 283 Often, the comments express regret at the omission of relevant factual information in state reports or point out issues under the ICCPR that the reports have failed to address in sufficient detail. ${ }^{284}$ In addition, they direct states to take account of the Committee's analysis in preparing future reports. ${ }^{285}$

The general comments provide a crucial opportunity for the Committee to articulate its understanding of the treaty's protected rights and freedoms. Although the first two comments concerned procedural aspects of the reporting process, ${ }^{286}$ the remainder have addressed the Committee's understanding of the substantive rights enshrined in the treaty. Most of these comments have analyzed individual articles of the ICCPR, such as the right to life protected in Article $6^{287}$ or the prohibition of torture in Article $7 .{ }^{288}$ But the

280. See Opsahl, supra note 17 , at $401-02$.

281. See id. at 407-09.

282. See Human Rights Committee, supra note 277, at 220-21 (criticizing states for late filings of reports).

283. Opsahl, supra note 17 , at 412 .

284. See id. at 414.

285. See MCGoLDRICK, supra note 17, at 94.

286. See General Comment $1 / 13$ (reporting obligation), July 28,1981 , reprinted in NowaK, supra note 15, at 848-49; General Comment $2 / 13$ (reporting guidelines), July 28, 1981, reprinted in NowaK, supra note 15 , at 849 .

287. See General Comment 14/23, Nov. 2, 1984, reprinted in NowAK, supra note 15, at 861; General Comment 6/16, July 27, 1982, reprinted in NowaK, supra note 15, at 851-52; see also Covenant, supra note 15 , art. 6, 999 U.N.T.S. at 174-75.

288. See General Comment 20/44, Apr. 3, 1992, reprinted in NowaK, supra note 15, ut 871-73; General Comment 7/16, July 27, 1982, reprinted in NowAK, supra note 15, at 852-53; see also Covenant, supra note 15, art. 7, 999 U.N.T.S. at 175. Other general comments have addressed gender equality, liberty and security of person, freedom of expression, procedural guarantees in civil and criminal trials, prohibition of propaganda for war and advocacy of hatred, the right of self-determination, the rights of the child, the right of nondiscrimination, and rights relating to marriage and the family. See NowaK, supra note 15, at 850-75 (reprinting comments). 
Committee has also adopted two issue-oriented comments, on the position of aliens $^{289}$ and on the rights of detainees. ${ }^{290}$

In developing its analysis, the Committee has relied on the expertise of individual members, information submitted by states parties in their reports, and cases decided under the Optional Protocol. ${ }^{291}$ Although adoption of the general comments has "serve[d] rapidly to develop the jurisprudence of the [Committee] under the Covenant," 292 the statements issued are not scholarly studies. Moreover, "since they are couched in general terms their interpretation may easily create problems of application to specific cases."293 In assessing the caliber of the Committee's analysis, one commentator states that while some of the comments "have been of a high quality and represent valuable indications of the content of the respective rights," others "have been much less helpful."294

\section{The Petition System}

The Committee's other major jurisprudential function is the consideration of written "communications" from individuals under the First Optional Protocol to the ICCPR. ${ }^{295}$ The Committee has taken on quasi-judicial functions in interpreting the treaty in these cases. ${ }^{206}$ Specifically, it acts as an arbiter of contentious disputes between individuals and states, provides victims of human rights violations with an international forum for relief where domestic remedies

289. See General Comment 15/27, July 22, 1986, reprinted in Nowak, supra nole 15, at 861-63

290. See General Comment 21/44. Apr. 6, 1992, reprinted in Nowak, supra note 15. at 873-75

291. See Opsahl, supra note 17, at 414; see also Optional Protocol, supra nute 15. 499 U N T S at 302.

292. MCGOLDRICK, supra note 17, at 95 .

293. Opsahl, supra note 17 , at 415 .

294. MCGOLDRICK, supra note 17, at 94; see also id. at 47 ! ("IT) General Comment on artucle 19 was both weak and disappointing, being liule more than a reltcratton of anticle 19")

295. See Optional Protocol, supra note 15, ant. 2, 999 U N.TS al 302 ("11]ndividuals who clam that any of their rights enumerated in the Covenant have been volated may submit a wnllen communicaltion to the Committee for consideration."). Under Article 41 of the ICCPR, states parties may recognize the competence of the Committee to consider a complaint filed by one state party aganst another alleging a failure to comply with the obligations of the Covenant. See Covenant, supra nole 15. art 41, 999 U N TS at 182-83. The Committee then assists the parties in resolving the dispule See id To date, however. no state has filed a complaint under the Article 41 procedure See Nowak, supra note 15, \& 580-603 (discussing the interstate petition procedure).

296. See, e.g., P.R. Ghandhi. The Human Rights Communter and the Right of Individual Communication, 57 BRIT. Y.B. INT'L L. 201, 249 (1986) ("Although. in no sense a court of law, the Committee has striven to be seen to be acting in a way as nearly as possible similar to that in which a court of law acts."); Opsahl, supra note 17, at 426-27 (noung thit the Committe "has applica basic principles of a judicial, or quasi-judicial nature concerning, for instance, contradictory procecdings, assessment of evidence, and reasoning in support of its results"): Alfred M. de Ziyas. The Follow. Up Procedure of the UN Human Rights Committee, 47 REV. INT'L COMM'N JURISTS 28. 30 (1991) ("Admultedly the Human Rights Committee is not ... a coun, but it does exercuse analogous responsibilutues and it is the only international body to fulfil this need."); Alfred de Zayas et al . Application of the International Coi enant on Civil and Political Rights Under the Optional Protocol by the Human Rights Commutter. 28 FR G Y B INT'L L. 9, 11 (1985) (“The Committee applies the provistons of the Covenant and Optuonal Protocol in a judicial spirit."). 
are unavailable or insufficient, and generates a "specific problem-centred jurisprudence."297

The Committee cannot perform these functions for all of the states party to the Covenant, however, since it is only authorized to consider complaints against states that have ratified the Optional Protocol. ${ }^{298}$ To date, only 86 of the 132 states parties have ratified that agreement. ${ }^{299}$ This creates a "double standard of adherence to covenant rights" in which states that have ratified the Optional Protocol are subject to a far greater level of scrutiny of their compliance with the ICCPR than states that have refrained from ratification..$^{300}$ For example, in contrast to its reluctance to criticize states parties during the reporting process, the Committee has not hesitated in expressing its displeasure with states that do not respond to an individual's allegations or otherwise decline to take an active role in resolving a case.

Even once a state has ratified the Optional Protocol, the ability to file a petition with the Committee is subject to several restrictions. First, only individuals can bring a complaint before the Committee; a group cannot file a claim on an individual's behalf. ${ }^{301}$ Second, if the laws of the state provide domestic remedies for the alleged violations of the ICCPR, those remedies must be exhausted prior to filing a communication with the Committee. ${ }^{302}$ Third, the communication must not be an abuse of the right of submission, anonymous, or otherwise "incompatible with the provisions of the Covenant." ${ }^{\text {"303 }}$ Fourth, the communication must not be under consideration by another international monitoring body. ${ }^{304}$ Finally, the individual must provide sufficient facts to substantiate his or her allegations. ${ }^{305}$

297. Matthew Craven, Towards an Unofficial Petition Procedure: A Review on the Role of the UN Committee on Economic, Social and Cultural Rights, in SOCIAL RIGHTS AS HUMAN RIGHTS: A EUROPEAN Challenge 91, 94 (Krzysztof Drzewicki et al. eds., 1994). A former member of the Committec recently highlighted the interrelationship between the reporting system and the petition system:

Consideration of states' reports gives the Committee an overall picture of the situation with regard to civil and political rights in a given country. This panorama is indispensable to the evaluation of a state's compliance with international human rights standards. . . .

But frequently details are lost (and I would like to emphasize that in the protection of basic human rights and freedoms all details are very important). Very often, it is only through the consideration of individual communications that complete conformity of national legislation and practice with the requirements of international law can be assessed.

Rein A. Myullerson, Monitoring Compliance with International Human Rights Standards: Experience of the UN Human Rights Committee, 1991-1992 CAN. HuM. RTs. Y.B. 105, 107.

298. See Optional Protocol, supra note 15, an. I, 999 U.N.T.S. at 302.

299. See Human Rights CommitTeE PRESS Release, supra note 15.

300. Anne F. Bayefsky, Human Rights: The 1966 Covenants Twenty Years Later, 80 AM. SoC'Y INT'L L. PROC. 408,409 (1986).

301. See NowAK, supra note 15 , at $657-59,681$.

302. See Optional Protocol, supra note 15, art. 2, 999 U.N.T.S. at 302.

303. Id. art. 3, 999 U.N.T.S. at 302. Grounds for declaring a communication inadmissible under this clause include incompatibility ratione temporis, personae, loci, and materiae. See NowaK, supra note 15, at $678-85$.

304. See Optional Protocol, supra note 15, art. 5(2), 999 U.N.T.S. at 303.

305. See NowaK, supra note 15 , at $666-68$. 
Assuming an individual overcomes these hurdles, the Committee declares the communication admissible and then receives written submissions by both the aggrieved individual and the state party. The Committee cannot engage in factfinding and it does not take testimony or hear oral arguments from the parties. ${ }^{306}$ After reviewing the written submissions, the Committee determines in a private meeting whether the facts presented disclose a violation of the Covenant.

The Committee then authors an opinion, ambiguously referred to in the Optional Protocol as the "views" of the Committee. ${ }^{307}$ These views, which "follow a judicial pattern and are effectively decisions on the merits," forth the allegations of the author, the responses of the state pary, the decision on admissibility, and any interim measures, followed by the facts upon which the Committee bases its decision. The views also list certain "considerations" upon which the Committee has based its decision. These include a state pary's degree of cooperation with the Committee in resolving the case, the burden of proof, a reference to one or more general comments or to prior case law, and an interpretation of the substantive requirements of the treaty. ${ }^{3(r)}$ Finally, the decisions contain a statement of "the view of the [Committee] on the 'obligation' of the State party in light of [its] findings."

From the inception of the petition procedure in 1977 through October 1996, the Committee had registered 716 communications concerning fifty-one states parties. ${ }^{311}$ Of these, 239 had been concluded with the adoption of views on the merits. ${ }^{312}$ Of the remaining communications, 224 had been declared inadmissible, 115 had been discontinued or withdrawn by the author, and 96 were pending as of October 1996 at the pre- or post-admissibility stage. $^{313}$

\section{B. Toward an Increasingly Judicial Approach to the Petition System}

Although the foregoing summary reveals the diverse functions that the Committee exercises in monitoring states parties' compliance with the

306. See MCGoLDRICK, supra note 17, at 134, 143-45 MoGoldnck notes that the Optunal Prutocol does not preclude the Committe from heanng oral argument See id at $1+4-45$

307. See Optional Protocol, supra note 15, an 5(-4). 999 UN T S al 303

308. MCGOLDRICK, supra nole 17, at 151

309. See id.

310. Id. at 152. Once adopied, the Committee forwands its veus to buth parties and publishes them. along with selected admissibility decisions. in tis annual repon to the General Assembly Ser Optional Protocol, supra note 15, ant. 5(4), 999 U.N.T S at 303

311. See Consideration of Communcanons Under the Ophomal Prosocol, L $\therefore$ GAOR, Hum Rts Comm., SIst Sess., Supp. No. 40, al 66, UN Doc A51140 (1996) |hereinstles 1946 Consideration of Communications].

312. See id. As of October 1995, the Commitec had found uesty violdtons in 154 of the 208 decisions on the merits. See Follow-Up Acmines Under the Optronal Protocul, L A GAOR. Hum Rts Comm., 50th Sess., Supp. No. 40, at 96. UN Doc A50/40 (1995) (hereindler /995 Follow -Up Achuthes)

313. See 1996 Consideranon of Conmumcahons, supra nute 311, at 66 
Covenant, it is the consideration of communications under the Optional Protocol that has recently brought the most attention to the Committee and its work. In addition, the increasing number of states that have ratified the Optional Protocol over the last decade, ${ }^{314}$ together with the widening audience of litigants, attorneys, activists, and scholars who follow the Committee's activities, has made the petition system an ever more important part of its work. With greater visibility has come a concomitant rise in the number of communications filed with the Committee and an increase in their complexity. ${ }^{315}$

The Committee's response to these developments reveals a trend of remarkable importance: In numerous and diverse ways, the Committee is behaving more and more like a judicial arbiter of human rights disputes, even when granted only limited powers by states parties. Although lacking many of the institutional characteristics possessed by supranational tribunals such as the ECHR, the ECJ, and the European Commission of Human Rights, the Committee has, within the limits of its authority and sometimes arguably beyond it, followed an increasingly court-like method of operation. Particularly striking, in light of our analysis of effectiveness in Part 1 , are the Committee's efforts to improve compliance with its decisions.

Since 1990, the Committee has become quite outspoken in its view that defending states are under an obligation to comply with unfavorable decisions against them. ${ }^{316}$ Further, it has taken concrete steps to monitor compliance, appointing one of its members as a special rapporteur to record states' responses. ${ }^{317}$ As of October 1995, the rapporteur had received information

314. As of 1991, only 55 States had ratified the Optional Protocol. See Opsahl, supra note 17, at 421. As of late 1995, 86 States had done so. See UNITED NaTions, ECONOMIC AND SOClal Council, HUMAN RIGHTS COMMITTEE, PRESS RELEASE: HUMAN RIGHTS COMMITTEE CONCLUDES FIFTY-FIFTH SESSION AT GENEVA, U.N. Doc. HR/CT/448 (1995).

315. Although the Committee's early case law generally concerned gross violations of human rights or situations that required only a cursory legal analysis, more recently the Committee has begun to consider cases that require "more subtle legal reasoning." Opsahl, supra note 17, at 428, 429.

316. Although the Committee's early decisions failed to announce whether states were obliged to inform the Committee of their responses to its views, in 1990 the Committee began concluding its decisions with the statement that it "would welcome information on any relevant measures taken by the State party in respect of the Committee's views." See, e.g., Torres v. Finland, No. 291/1988, U.N. GAOR, Hum. Rts. Comm., 44th Sess., Supp. No. 40, Annex IX, at 96, 100, U.N. Doc. A/44/40 (1990). The Committce's current practice is to ask for a response from the defending state within 90 days in each case in which it determines that a violation of the ICCPR has occurred. See, e.g., Linton v. Jamaica, No. 255/1987, U.N. GAOR, Hum. Rts. Comm., 48th Sess., Supp. No. 40, Annex XII, at 12, 16, U.N. Doc. AV48/40 (1993).

317. Prior to 1990 , a dispute among the members over the legal basis for initiating any follow-up procedures prevented the Committee from assessing the extent of compliance. See de Zayas, supra note 296, at 30-31. In that year, however, the Committee resolved this internal debate and appointed the special rapporteur. See Measures Adopted at the Thirty-Ninth Session of the Human Rights Conmittee To Monitor Compliance with Its Views Under Article 5, Paragraph 4, of the Optional Protocol to the Imternational Covenant on Civil and Political Rights, U.N. GAOR, Hum. Rts. Comm., 45th Sess., Supp. No. 40, Annex XI, at 205, 205-06, U.N. Doc. A/45/40 (1990). The Committee published an analysis of the intormation received by the rapporteur in its 1993 annual report to the Gencral Assembly, see Follow-Up on Views Adopted Under Optional Protocol to the International Covenant on Civil and Political Rights, U.N. GAOR, Hum. Rts. Comm., 48th Sess., Supp. No. 40, Annex X(B), at 222, 223-24, U.N. Doc. AN48/40 (1993) 
in 81 of 154 views in which the Committee found a treaty violation. ${ }^{318}$ of the responses received, the Committee considered only about thirty percent to be "satisfactory," meaning "that they display[ed] a willingness on the part of the State party concerned to implement the Committee's Views or to offer the applicant an appropriate remedy." 319 In light of this lukewarm response by states parties, the Committee has taken steps to increase adherence to its decisions. Specifically, it has begun to publish the compliance information it collects and to identify publicly each state that refuses to implement its views. $^{320}$

In view of the Committee's own efforts to improve its performance as an increasingly judicial supranational tribunal, it is appropriate and timely to apply the checklist of factors outlined above to the Committee's review of individual petitions under the Optional Protocol. In the subsections that follow, we review the Committee's performance with respect to each of the checklist factors, noting in each instance whether the current status of that factor favors or hinders the Committee's openly professed desire to achieve more effective supranational review of states parties' human rights practices. Where the current status of a particular checklist factor appears to be less than optimal, we also briefly indicate additional steps that states or the Committee itself might take to achieve greater effectiveness.

\section{Factors Principally Within the Control of States Parties}

\section{a. Composition of the Tribunal}

Article 28 of the Covenant provides that the Committer "shall be composed of nationals of states party to the present Covenant who shall be of high moral character and recognized competence in the field of human rights, consideration being given to the usefulness of participation of some persons having legal experience." ${ }^{321}$ This raises an immediate problem with treating

[hereinafter 1993 Follow-Up on Views], and a similar andlysis has been published each year therealler

318. See 1995 Follow-Up Activttes, supra note 312. at 96

319. Id. The remaining responses

either explicitly challenged the Commilice's findings on factual or legal grounds (nine replites).

indicated that the State party would not, for one redson or anuther, give ellect to the

Committee's recommendations (nine replies), promised an investigation of the matter considered

by the Committee or constituted much belated submissions on the ments of the wase

Id. On the whole, the Committee characterized these statustucs as "encouraging" but "nut lully salislactury " Id. at 98 .

320. In 1995, the Committee published what it Icrmed a "separale and highly issible chapter un follow-up activities under the Optional Protocol " Id at 99 This chupter includes a list identifying thuse states that cooperated with the Committec's follow-up procedures and thuse that did nut Ser ad at 97.98 The Commitlee has also resolved to give "|e|very form of publicily" to its folluw -up procedures. ind luding issuing separate press communiques "highlightıng both postuve and negatuve develupments." meetıng wath government representatives, and unging nongovemmental organiations to submit infurmation on compliance. Id. at 99-100.

321. Covenant, supra note 15, an. 28(2). 999 UN T S at 179 
the Committee as analogous to other supranational tribunals; unlike members of the ECHR and the ECJ, ${ }^{322}$ its members need not be lawyers or jurists. In practice, however, "nearly all members of the Committee have completed a legal education and are or were employed in the legal field," 323 a fact which commentators believe has resulted in the "high quality of decisions on individual communications. ${ }^{\text {"324 }}$

Although all of the Committee members are acknowledged experts in human rights, the background and experience of individual members vary considerably. Most have worked as university professors specializing in public international law; others are judges, prosecutors, lawyers, diplomats, public officials, or politicians. ${ }^{325}$ Because the Committee works on a part-time basis, generally taking up no more than two months of each year, ${ }^{326}$ its members often simultaneously work for regional tribunals such as the ECHR, the European Commission of Human Rights, or the Inter-American Commission on Human Rights, or U.N. treaty or political bodies such as the Committee Against Torture, the United Nations Human Rights Commission, and the General Assembly. ${ }^{327}$ Members may also be public servants of their states or occupy government office, ${ }^{328}$ a status that raises a potential conflict with the Committee's obligations of independence and impartiality.

Given the broad mix of experience among the Committee members, the present composition of the Committee may well be suitable for achieving its professed goal of encouraging states parties to implement its interpretations of the Covenant. This factor is thus likely to be a net plus in assessing the Committee's performance under the checklist. If the experience with the ECJ and the ECHR is any guide, however, states parties should refrain from nominating active government officials to the Committee. They should also consider increasing the number of Committee members with substantial experience and recognized expertise in national law since these individuals may more effectively bridge the gap perceived by national legislators and judges between international and national law. Finally, states parties should also consider other structural changes to the Covenant and the Optional Protocol in order to increase the quasi-judicial nature of the Committee. Possible reforms include increasing the term of member's service from its current four years and permitting automatic reelection of Committee members without the need for renomination by a state party. ${ }^{329}$

322. See supra Subsection III.B.1.a.

323. NoWAK, supra note 15 , at 508 .

324. Id.

325. See id. at 508-09 (listing members of the Committee and their professions as of 1993).

326. See id. at 529.

327. See id. at 508-09 \& n.12.

328. See id. at 509. As of 1993, only two of the Committee's 18 members were civil servants. See id.

329. See Covenant, supra note 15, arts. 30, 32, 999 U.N.T.S. at 180 (describing current election and nomination procedures). 


\section{b. Case Load or Functional Capacity of the Tribunal}

The early days under the Optional Protocol brought disappointingly few communications to the Committee. ${ }^{330}$ During the 1980s, the Committee reached only five to ten decisions on the merits each year. ${ }^{311}$ More recently, however, the Committee's case load has begun 10 increase "markedly":"13 Between October 1993 and July 1994, the Committee adopted thirty-two "views" on the merits and declared thiry cases to be inadmissible;" another fifteen views and thirteen admissibility decisions were reached during the next year. ${ }^{334}$ During this period, the number of communications filed with the Committee also increased. ${ }^{335}$

Although the Committee's workload is burgeoning and must be regarded as respectable for a fledgling supranational tribunal in the first twenty years of its existence, ${ }^{336}$ it is still quite modest given the large number of states party to the Optional Protocol (at eighty-six more than twice the number of signatories to the European Convention on Human Rights) ${ }^{337}$ and the vast number of human rights violations occurring every year around the world. Two related factors help explain the relative paucity of cases: the inadequate resources provided to the Committee and the lack of knowledge on the part of potential plaintiffs of the Optional Protocol's function or existence. "is

The material and financial support necessary to create the physical and personal infrastructure for rendering decisions is a critical factor in the

330. See MCGOLDRICK, supra nole 17, at 500 ("The most disappointung teature of the prattice under the Optional Protocol had perhaps been the limited number of communications but there has been a substantial increase in recent years.")

331. See ROBERTSON \& MERRILls, supra note 81 , at 65 This hgure does not include published decisions declaring communications ınadmissiblc

332. Repon of the Human Rights Conmuttee to the General Assembh. L'N GAOR. Hum RLs Comm., 49th Sess., Supp No. 40, at 5. UN Doc No N49/40 (1944) (heteinalter /9y4 Humun Rigins Committee Report].

333. See Consideranon of Communcanoms Under the Ophonal Protocol. L'X GAOR. Hum RLs Comm., 49th Sess., Supp. No. 40, at 64. U.N Dox AV49/40 (1994) (hereanalter / yyt (onsulcration of Communications].

334. See Consideraton of Communtanons Under the Ophomal Protocol. L' $X$ CAOR. Hum RLs

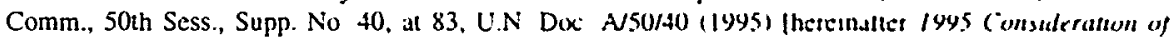
Communications].

335. See id. at 82 .

336. It should be remembered that the number of complants $h_{1} l e d$ with the Eurupean Commissun of Human Rights (and, as a result with the ECHR) was extsemely low for the tist iwo deculds of the tribunals' existence and only increased in the late 1970s and cally 1980s allet the ECIRR dichded xelcial landmark judgments against the states party to the European Conicnton See e g. Brtit)akb), supra nute 86, at 6-7; ROBERTSON \& MERRILLS, supra note 81. dt 310.11

337. Compare text accompanying supra note 79. wilt supra note 15

338. See MCGOLDRICK, supra note 17, at 500 Commentators hase also passted a thred lator the siphoning off of potential clatmants by other international dedudication procedures See al The poltental for such intersystem competition is limited, however, given that mans stales party to the Covenant and the Optional Protocol are not also members of the Europedn or American regtunal humsn nghts regimes In addition, in the absence of a reservation to the Optionsl Protocol, a human right platnull mas bring a complaint before a regional human nghts inbunal and then. 11 rejected. belure the Cummitec 
Committee's ability to enhance its effectiveness. ${ }^{339}$ Members of the Committee are chronically starved for resources. They must follow all proceedings while simultaneously preparing interventions and responding to or commenting on state reports covering complex issues of law and fact. ${ }^{340}$ Most observers conclude that members of the Committee do more than can reasonably be expected, making it impossible for the Committee to assume added work or to work between sessions without substantial additional resources. ${ }^{341}$ The Committee has repeatedly requested such resources from the United Nations, most recently stressing that it could "no longer examine communications expeditiously" in light of its increasing workload and "highlight[ing] the urgent need to reinforce the Secretariat staff." analysis confirms the vital importance of responding to this request.

One way to increase the Committee's caseload without overstraining existing resources would be to streamline its procedures. At present, proceedings under the Optional Protocol are quite drawn out, lasting two to three years. ${ }^{343}$ The states party to the ICCPR could revise the procedures to reduce delay and increase access. For example, the states parties could permit the Committee to decide cases in geographically representative panels with en banc review by the Committee reserved for exceptional cases. ${ }^{344}$

The low, albeit rising, public profile of the Committee's mandate and its case law also explains the relatively modest number of views decided to date. The Optional Protocol procedure is not widely known to national lawyers and

339. Pursuant to Article 36 of the Covenant, "[t]he Secretary-General of the United Nations shall provide the necessary staff and resources for the effective performance of the functions of the Committee under the present Covenant." Covenant, supra note 15, art. 36, 999 U.N.T.S. at 181.

340. See Opsahl, supra note 17, at 433-43. Indeed, Committee members often feel overwhelmed by their heavy workload. See MERRILLs, supra note 77, at 16.

341. See Opsahl, supra note 17, at 381. To reduce the backlog of pending cases under the Optional Protocol, the Committee met an extra week during its 51st session, adopting 16 views and declaring 11 decisions inadmissible. The U.N. Secretary General's failure to provide more staff for this extended scssion, however, resulted in an increased backlog in the processing of new communications. See 1994 Consideration of Communications, supra note 333, at 65.

342. 1995 Consideration of Communications, supra note 334, at 83. The Committee stated further:

[T]he Committee also notes that an increasing number of communications are being submitted in languages which are not among the working languages of the Secretariat, and expresses its concern about the consequent delays in the examination of such communications. The Human Rights Committee reiterates its request to the Secretary-General to take the necessary steps to ensure a substantial increase in the number of staff, specialized in the various legal systems, assigned to service the Committee, and wishes to record that the work under the Optional Id. Protocol continues to suffer as a result of insufficient Secretariat resources.

343. See id.; see also de Zayas et al., supra note 296, at 16.

344. In the absence of such formal revisions, the Committe has implemented several procedures to streamline its examination of communications, including appointing a special rapporteur to process new communications, authorizing a five-member working group that can declare communications admissiblc when all five members agree, and joining consideration of the admissibility and merits of a communicution when both parties consent and the Committee considers it appropriate. These measures have helped to reduce the backlog of cases, albeit to a limited degree. See NowAK, supra note 15, at 688 (noting that the establishment of the rapporteur on new communications has reduced the backlog of cases pending at the pre-admissibility stage). 
advisors in the states parties. ${ }^{345}$ Even though respected for its moral and legal authority as an independent human rights body, the Committee still receives comparatively little interest at either the popular or academic level. ${ }^{3+6}$ The Committee, appreciating the need for greater awareness of its work, has recently taken steps to publicize its activities. In particular, it has authorized the holding of press briefings at each of its sessions, encouraged information exchanges with nongovernmental organizations, urged the media to become more acquainted with its activities, and expedited the issuance of its official publications containing key documents and case law. ${ }^{347}$

In sum, the Committee scores quite low on this measure of effectiveness, both because of the inadequate resources devoted to the Committee's activities and because of the relatively limited use of the petition system by individual claimants. ${ }^{348}$ It would be easier to publicize the Committee's work, of course, if its decisions were formally binding. To this extent, publicity is likely to covary with other factors that we have identified. Another possibility for raising the profile of the Committee without necessarily changing the status of its determinations would be to amend the Covenant and the Optional Protocol to create new channels of access between it and national courts. If, for instance, national courts were allowed to submit questions arising under the Covenant to the Committee for determination, even if these courts were not formally bound by the resulting opinions, the Committee's influence would spread. States parties could explore such models of court-to-court communication without necessarily expanding the formal legal authority of the Committee.

\section{c. Independent Factinding Capacity}

Unlike other supranational courts, the Committee has no authority to conduct independent factfinding or to require states parties to supply information concerning an alleged treaty violation. ${ }^{344}$ Nor may it compel the parties or their representatives to appear before it in person to assess their credibility, query their proof, or evaluate their legal arguments. Instead, the Committee must merely consider the communications it receives "in light of

345. See MCGOLDRICK, supra note 17, at 500

346. See id. at 102. McGoldrick reports that academic altention to the actual practices of the LNHRC is now increasing. See id.

347. See Report of the Human Rights Comunntee to the General Assembly. UN GAOR. Hum Ris Comm., 50th Sess., Supp. No. 40, at 12, U.N. Doc. AV0/40 (1995)

348. We recognize, of course, that increasing the number of petitions filed with the Committee without a concomitant boost in its resources is a recipe for a backlogged docket and frustrsted clatmants Thus. the issue of adequate resources may well be the most critucal one facing states parties

349. Nor, like the ECJ, does the Commitce sit above tribunals that possess independent tattinding powers. See supra notes $122-123$ and accompanying text 
all written information made available to it by the individual and the State Party concerned." 350

Commentators have uniformly criticized the Committee's limited powers in this regard, noting that the current procedure is "unsatisfactory" "has considerably restricted the possibilities for adequate taking of evidence" since the Committee is unable to verify "conflicting depictions of the facts," either by "oral examination of parties or witnesses or by on-site inspection." 352 Accordingly, these commentators have urged the Committee, with the consent of the state party concerned, to hold oral hearings and conduct on-site investigations. ${ }^{353}$ Alternatively, the Committee may suggest, and states parties may seek, an amendment to the Optional Protocol to provide for such procedures.

Although hobbled by its limited textual mandate, the Committee has attempted to compensate for its limited powers by spelling out in detail what is expected of states parties when it brings a communication to their attention. In particular, the Committee has emphasized that a state "should make available to [it] all the information at its disposal," 354 including "copies of the relevant decisions of the courts and findings of any investigations which have taken place into the validity of the complaints made." ${ }^{355}$ The state must also "investigate in good faith all the allegations of violations of the Covenant against it and its authorities and furnish the Committee with detailed information about the measures, if any, taken to remedy the situation." 336

Notwithstanding these procedural requirements, in numerous cases the Committee has received either insufficient or no cooperation from the state involved. To prevent the truculent attitude on the part of such states from vitiating the Optional Protocol procedures, the Committee has developed a default judgment jurisprudence under which the author's plausible and substantiated allegations form the basis for its findings of fact and legal conclusion that the Covenant has been violated. ${ }^{357}$ Although attractive to individuals seeking to hold such states accountable for human rights abuses, this body of decisions nevertheless may be seen as crediting factual assertions

350. Optional Protocol, supra note 15, an. 5(1), 999 U.N.T.S. at 303.

351. MCGOLDRICK, supra note 17 , at 144 .

352. NoWAK, supra note 15 , at 692 .

353. See MCGoLDRICK, supra note 17, at 144-45; Opsahl, supra note 17, at 427. McGoldrick has stressed, however, that the Committee "could not cope with oral hearings without a fundamentul restructuring of its work and servicing." MCGoLDRICK, supra note 17, at 145.

354. Douglas v. Jamaica, No. 352/1989. U.N. GAOR, Hum. Rts. Comm., 49th Scss., Supp. No. 40, Annex X, at 42, 47, U.N. Doc. A/49/40 (1994).

355. Mojica v. Dominican Republic, No. 499/1991, U.N. GAOR, Hum. Rts. Comm., 49th Sess., Supp. No. 40, Annex IX, at 142, U.N. Doc. A/49/40 (1994); see also NowAK, supra note 15, at 694.

356. Minanga v. Zaire, No. 366/1989, U.N. GAOR, Hum. Rts. Comm., 49th Sess., Supp. No. 40, Annex X, at 65, 66, U.N. Doc. A/49/40 (1993).

357. See NowAK, supra note 15 , at 693 . 
that have not been fully substantiated ${ }^{358}$ or skiring difficult legal issues for want of any meaningful adversarial process. ${ }^{35 y}$ This factor, then, clearly weighs against effectiveness, although the Committee's creativity in attempting to close the Covenant's procedural gaps is commendable.

\section{d. Formal Authority or Status as Law.}

The domestic legal status of the Covenant and Optional Protocol, like that of other multilateral treaties including the Treaty of Rome and the European Convention on Human Rights, is a function not of international law but rather of the domestic constitutional and legislative regimes established by the states party to the treaty. In one major respect, however, the ICCPR differs significantly from the European treaty regimes: The "views" of the Committee are not binding under international law on the paries to the dispute before it. ${ }^{360}$ The Committee itself considers this fact "a major shortcoming in the implementation machinery established by the Covenant." 361

The ultimate power to make the Committee's decisions legally binding rests with the states party to the Covenant. Given that states have thus far refused to bind themselves, the Committee initially scores relatively low on this checklist factor as well. The Committee has not permitted states parties to control this issue entirely, however. To the contrary, the Commiltee has taken steps toward imbuing its views with a tone that suggests they are de facto legally binding in character. These steps include articulating in its case law and general comments an interpretation of the ICCPR strongly suggesting that its views must be obeyed ${ }^{362}$ and urging states parties to amend the Optional

358. For example, commentators have reponed that the Committe has hat panticular difticuliy in establishing the truth of allegations that individuals have been subject to arbitrary artest and detention See. e.g., de Zayas, supra note 296, at 36-37.

359. Cf MCGoLDRICK, supra note 17, at 367 (finding the Commuttec's sparse anslysts in carly decisions attributable in part to the states parties' fallure to particupate in the procecding and to provide counterarguments to the authors' allegations).

360. See id. al 151; NowaK, supra note 15, at 710; Opsahl, supra note 17. at +31

361. 1993 Follow-Up on Viess, supra note 317. at 222

362. In Bradshaw v. Barbados, No. 489/1992, UN. GAOR. Hum Ris Comm t thh Sess. Supp No 40, Annex X, at 305, 307, U.N. Doc. A49/40 (1994), the Count of Appeal of Bartusuos had rejected the argument of a death row inmate that "The provisions enabling wniten represenizitions to the Human Rughts Committee, and the procedural and other provisions thereunder." are pan of the law of Barbudos As a result, the defendant had no "legitimate expectatuon that the Sute would not carry out the sentente of dedth before his rights under the Covenant and the Optional Protocol hald teen constdered by the Committee . . ." Id. The Committe critucized this rejectuon of its powers in nu uniertan terms By ratifying the Covenant and the Optuonal Protocol. Barbsdus has undertaken to lultil its obligations thereunder and has recognized the Commilee's competence to recelve and consider communications from individuals .... Whale the Covenant is not pan of the domestic law of Barbados which can be applied directly by the courts, the Stale pany has nevertheless ateepted the legal obligation to make the provistons of the Covenant effecuve To this extent, it is an obligation for the State party to adopt appropnate measures to give legal elfect to the vieus of the Committee as to the interpretation and application of the Covenant in pariculds cases ansing under the Optional Protocol. This includes the Committec's views on the desirability of interim measures of protection to avoid irreparable damage to the vatum of the alleged 


\section{Protocol to make the Committee's views legally binding. ${ }^{363}$}

\section{Factors Within the Control of the Tribunal}

\section{a. Awareness of Audience}

The Committee is highly aware that its audience under the Optional Protocol is comprised principally of individuals who have been aggrieved by a state party's alleged violations of their human rights. Thus the Committee has repeatedly "stressed the fundamental importance of individuals having access to it under the [Optional Protocol]." 364 In terms of admissibility requirements, ${ }^{365}$ exhaustion of domestic remedies, ${ }^{366}$ and the burden of persuasion, the Committee has interpreted the Optional Protocol in a manner favorable to individuals, thereby encouraging them to bring communications before it. This trend has been extensively documented by commentators. ${ }^{367}$

A second audience for the UNHRC is the lawyers who represent individuals before the Committee. Their participation has increased roughly in proportion to the rise in complaints generally, but at roughly fifty percent it has remained steady as a percentage of total cases filed. ${ }^{368}$ Representation by attorneys is particularly common in disputes involving states that are among

violation.

Id. at 309 .

In its recent general comment on the compatibility of state party reservations to the Covenant and the Optional Protocol, the Committee stated that its role under both treaties "necessarily entails interpreting the provisions of the Covenant and the development of a jurisprudence." General Comment No. 24(52) on Issues Relating to Reservations Made upon Ratification or Accession to the Covenant or the Optional Protocols Thereto, or in Relation to Declarations Under Article 41 of the Covenant, U.N. GAOR, Hum. Rts. Comm., 50th Sess., Supp. No. 40, Annex V, at 126, U.N. Doc. AV50/40 (1995). The Committec further stated that "a reservation that rejects the Committee's competence to interpret the requirements of any provisions of the Covenant would also be contrary to the object and purpose of that treaty." Id.

363. In 1993, the Committee urged states parties to amend the Optional Protocol to "undertake to comply with the Committee's views." 1993 Follow-Up on Views, supra note 317, at 225. Given that more than one-third of the states party to the Covenant have thus far refrained from ratifying the existing Optional Protocol, such a move is remarkably bold and forward-looking.

364. MCGOLDRICK, supra note 17, at 199.

365. See ZWART, supra note 17 , at $150-52$.

366. See MCGOLDRICK, supra note 17, at 197 (observing that the Committee has adopted "an individual orientated approach, or at least not a State centred approach" to exhaustion of domestic remedies); NowAK, supra note 15, at 703-04 (noting that the Committec has generally interpreted the exhaustion requirement more liberally than has the European Commission of Human Rights).

367. See, e.g., MCGOLDRICK, supra note 17, at 198-204; NowAK, supra note 15, at 675-707; ROBERTSON \& MERRILLS, supra note 81, at 54-69; Ghandhi, supra note 296; de Zayas et al., supra note 296.

368. A rough comparison of the number of cases in which an individual was represented by counsel (a fact always noted by the Committee on the first page of its decision) in the 37th session as compared to the 49th session illustrates this constancy. During the $37 \mathrm{th}$ session (in the carly 1980s, when the Committee first began hearing a regular stream of individual complaints), four of seven communicutions were submitted by counsel. See Report of the Human Rights Committee to the General Assembly, U.N. GAOR, Hum. Rts. Comm., 37th Sess., Supp. No. 40, at 141, U.N. Doc. A/37/40 (1982). At the 49th session in 1993-1994, 32 of 60 communications were submitted by counsel. See 1994 Human Rights Committee Report, supra note 332 , at 64-66. 
the most frequent defendants before the tribunal. ${ }^{369}$ To the extent that these legal representatives also practice before domestic courts and interact with judges and other legal decisionmakers at the national level, there is increased opportunity for the Committee to disseminate and publicize its views. There is also a greater likelihood that these attorneys will cite the Committee's decisions as a means of influencing the rulings of national cours, thereby leading to enhanced dialogue between the Committee and national courts.

Finally, in recent years, the Committee has targeted its decisions squarely at national courts. In Sara $v$. Finland, ${ }^{370}$ for example, the Committee declared a communication inadmissible after finding that the authors, in challenging Finnish law before national courts, had not argued that the law violated the ICCPR. In a move strikingly similar to that taken by the ECJ in Van Gend \& $\operatorname{Loos}^{371}$ and its progeny, the Committee praised the Finnish courts for their increasing reliance on international human rights standards ${ }^{372}$ and indicated that it would decline to review challenges to Finnish laws where the complainants had failed to raise treaty-based arguments before the Finnish courts. $^{373}$ In this way, the Committee simultaneously promised greater deference to those national courts that invoke the standards of the Covenant in domestic law and encouraged individuals to refer communications to it as the final arbiter of the Convention's meaning. The Committee may thus have established the foundation for a relationship similar to that forged by the ECJ with European national courts. For all of these reasons, the Committee scores positively on this checklist factor, following in the footsteps of its regional counterparts.

\section{b. Neutrality and Demonstrated Autonomy' from Political Interests}

Notwithstanding its limited resources and the vast and divergent national legal systems of the states parties it oversees, the UNHRC has shown an increasing willingness to find national governments to have breached their human rights obligations. It has done so, however, only after ensuring that a

369. These states include Jamaica and the Netherlands At the 49th session. nine out of eleven communications concerning Jamaica, as well as seven out of nine communicaltuns conceming the Netherlands, were presented by counsel. See 1994 Human Rightss Commuttee Repart. supra nole 332. al 6466.

370. No. 431/1990, U.N. GAOR, Hum. Ris. Comm. 49th Sess., Supp No 40. Annex X. st 257. 267. U.N. Doc. A/49/40 (1994).

371. Case 26/62, N.V. Algemene Transp. \& Expediue Ondememing Van Gend \& Loos v Nederlandse administratie der belastingen, 1963 E.C.R. 1.

372. See Sara, U.N. GAOR at 267 ("IT]he Finnish judicial authonues have become increasingly aware of the domestic relevance of international human nghts standards. including the nghts enshrined in the Covenant.").

373. The Committee's practice also parallels that of the ECHR in Van Oostenuyck v Belgumn. 40 Eur Ct. H.R. (ser. A) at 16-17 (1980), in which the cour dismissed the case for falure to rase trealy-based arguments before national courts. See supra note 163 and accompanying text 
complainant has satisfied important procedural and substantive thresholds of proof that a treaty violation has occurred.

For example, on the one hand, the Committee has refused to permit states to evade their treaty obligations by declining to participate in proceedings under the Optional Protocol. Such a stance results in the finding of a violation by default where the author of a petition can substantiate his or her allegations that such a violation has occurred. ${ }^{374}$ And where a state directly flouts the Committee's authority, the Committee has not hesitated to express its condemnation in no uncertain terms. ${ }^{375}$ On the other hand, the Committee has required each complainant to demonstrate that his or her communication is admissible - for example, that he or she has exhausted domestic remedies $^{376}$ - and to provide credible evidence of a human rights violation, even where the state party refuses to challenge his or her allegations. ${ }^{377}$

Further evidence of the Committee's autonomy from political interests can be found in its increasing willingness to adopt an interpretation of the Covenant that is at odds with the positions espoused by states parties. Indeed, although in several of its early rulings the Committee appeared somewhat reluctant to question states parties' arguments, ${ }^{378}$ more recently it has decided

374. See, e.g., Mojica v. Dominican Republic, No. 499/1991, U.N. GAOR, Hum. Rts. Comm., 49th Sess., Supp. No. 40, Annex IX, at 142, 144, U.N. Doc. AV49/40 (1994) (explaining that, in the absence of participation by the state party in Optional Protocol proceedings, "due weight must be given to the author's allegations, to the extent they have been substantiated"); see also MCGOLDRICK, supra note 17, at 149 (noting that "no State party can benefit from its failure to co-operate fully" with the Committec).

375. See 1994 Consideration of Communications, supra note 333, at 70-71 (expressing "indignation" at Trinidad and Tobago for flouting the Committee's request not to execute a defendant pending consideration of his allegations by the Committee and noting that the State's action "has no precedent in the Committee's practice in capital cases under the Optional Protocol").

376. See, e.g., Amisi v. Zaire, No. 497/1992, U.N. GAOR, Hum. Rts. Comm., 49th Sess., Supp. No. 40, Annex X, at 310,311 , U.N. Doc. AV49/40 (1994) (declaring a communication inadmissible where the author failed to provide information on the exhaustion of domestic remedies). See generally MCGOLDRICK, supra note 17, at 134-41 (discussing "admissibility conditions" that petitioners must satisfy). It should be noted, however, that the Committee has not adopted an unduly strict reading of its admissibility criteria. Thus, for example, it does not require the exhaustion of available domestic remedics if exhaustion would be futile or would require an extreme delay in the proceedings. See, e.g., Blanco v. Nicaragua, No. 328/1988, U.N. GAOR, Hum. Rts. Comm., 49th Sess., Supp. No. 40, Annex IX, at 12, 17, U.N. Doc. A $49 / 40$ (1994) (holding that the author of a communication need not exhaust domestic remedies that became available after the submission of a petition where "the application of such remedies would entail an unreasonable prolongation of the author's quest to be vindicated for his detention and alleged illtreatment").

377. See Grant v. Jamaica, No. 353/1988, U.N. GAOR, Hum. Rts. Comm., 49th Sess., Supp. No. 40, Annex IX, at 50, 56, U.N. Doc. A/49/40 (1994) (finding no ill-treatment where police were cross-examined on this issue by the author's attorney in national court proceedings and the author failed to provide any supporting medical evidence); Blanco, U.N. GAOR at 18 (noting that although the author presented insufficient information to substantiate the allegation of discrimination, the allegations of torture and illtreatment were substantiated by "very detailed" allegations mentioning the names of officers responsible for, and witnesses to, ill-treatment); see also A.R.U. v. Netherlands, No. 509/1992, U.N. GAOR, Hum. Rts. Comm., 49th Sess., Supp. No. 40, Annex X, at 327, 329, U.N. Doc. A/49/40 (1994) (articulating the same principle); Barry v. Trinidad \& Tobago, No. 471/1991, U.N. GAOR, Hum. Rts. Comm., 49th Sess., Supp. No. 40 , Annex X, at 283,285 , U.N. Doc. A/49/40 (1994) (declaring a communication inadmissible because the author "failed to substantiate" his allegations).

378. See Bayefsky, supra note 300 , at $409-12$ (analyzing the early case law). 
several controversial cases in favor of individuals over the opposition of national governments and has not shirked from espousing a rights-protective interpretation of the Covenant. ${ }^{379}$ Given the rising number of states party to the Optional Protocol and the Committee's increasingly sophisticated legal reasoning, this jurisprudential trend is likely 10 continue. ${ }^{380}$ On balance. therefore, this factor cuts in favor of the Committee's effectiveness.

\section{c. Incrementalism and Awareness of Political Boundaries}

In its early years, the Committee moved forward cautiously, developing a consensus procedure notable for its absence of politicization and open conflict. This approach allowed the Committee to gain the confidence and respect of states parties. ${ }^{381}$ Additional beneficial contacts between the Committee and states parties occur in the Covenant's reporting procedures, through which the Committee strives to maintain a constructive dialogue with government representatives. ${ }^{382}$

The Committee has developed a similar approach under the Optional Protocol, often following the lead of the ECJ and national courts in articulating its most controversial and rights-protective interpretations of the Covenant in decisions giving judgment in favor of states parties. ${ }^{363}$ In this way, the

379. See, e.g., Toonen v. Australia, No. 488/1992, U.N GAOR. Hum. RLs Comm . 49h Sess. Supp No. 40, Annex X, at 226, 234, U.N. Doc. A/49/40 (1994) (holding that criminal prohibition of same-sex conduct between consenting adults in private violates the rights of pnvacy and nondiscrimunatuon); Mukong v. Cameroon, No. 458/1991, U.N. GAOR, Hum. Ris Comm. 49th Sess. Supp No 40. Annex IX. at 171. 181, U.N. Doc. A/49/40 (1994) (holding that the arrest and detention of a candidate of a political opposition party was not "necessary for the safeguard of national secunty and/or public order" and thus violated the right to free expression); $\mathrm{Ng}$ v. Canada, No. 469/1991, UN GAOR, Hum Rts Cumm, t9rh Sess. Supp. No. 40, Annex X, at 189, 205, U.N. Doc. A/49/40 (1993) (staling that the extradition of defendant to face death by gas asphyxiation is crucl and inhuman treatment). Balliantyne V Caniada, Nos $359 / 1989$ \& 385/1989, U.N. GAOR, Hum. Rts. Comm., 48th Sess., Supp No 40. Annex XII. al 91. 103. UN Doc A/48/40 (1993) (holding that Quebec's French-only sign law volates the nght of free expression). see also NowaK, supra note 15, at 461 (noting that the Committec's ruling in several cases ayalnst the Netherlands that Aricle 26 of the Covenant provides "substanuve equality for women in soctal law" made headlines and prompted the Netherlands to consider denunciation of the trealy and re-ralufication with a reservation to Aricle 26).

380. See Laurence R. Helfer \& Alice M. Miller. Sexual Orientanon and Human Rights Tow ard a U S and Transnational Jurisprudence, 9 HARV. HUM. RTS. J 61. 74 (1996) (notung that the Commuttec's recent practice reflects a willingness to decide cases against states panties)

381. See MCGOLDRICK, supra note 17, at 503.

382. See NowAK, supra note 15 , at 562 . McGoldnck argues that "[c]ountry specific comments and reports which alienated the States parties, divided the [Committee] and polutucized its proceedings would have achieved little in the long term." MCGOLDRICK, supra nolc 17. at 503

383. See, e.g., Casanovas v. France, No. 441/1990. U.N. GAOR. Hum Rts Comm , 4th Sess . Supp No. 40, Annex IX, at 131, 134-35, U.N. Doc. A/49/40 (1994) (finding that a challenge belore an administrative tribunal to dismissal from civil service employment is encompassed within Arucle it's requirement that any "suit at law" include a faur heanng. but refusing to find a violation on the farts presented); Santacana v. Spain, No. 417/1990, U.N. GAOR. Hum Ris. Comm . 4hth Sess. Supp No 40. Annex LX, at 101, 111-12, U.N. Doc. A/49/40 (1994) (adopting a broad definution of family under Arucle 23 but finding no violation of the right to found a family on the facts presented). Bnnkhof $v$ Netherlands. No. 402/1990, U.N. GAOR, Hum. Rts. Comm., 48th Sess., Supp. No 40, Annex XIl, al 124, 129. UN Doc. A/48/40 (1993) (concluding that "no differentiation shall be made among constienuous abjectors on 
Committee has succeeded in advancing an interpretation that favors individuals while at the same time diffusing opposition by states parties. ${ }^{384}$

Nevertheless, the Committee is keenly aware of the political limits of its decisions. Thus, for example, both precedent and logic dictate that where a state ratifies the Optional Protocol some years after it has ratified the Covenant, the Committee is competent to consider allegations of human rights violations that occurred during the interim period. ${ }^{385}$ In practice, however, the Committee has refused to entertain such petitions, ${ }^{386}$ perhaps fearing negative political consequences from the large number of communications that would likely follow such a ruling. ${ }^{387}$ On balance, its incremental approach has probably worked in its favor, particularly given the specific political constraints imposed by the Cold War.

\section{d. Quality of Legal Reasoning}

The importance of the quality of the Committee's legal reasoning to its stature as a quasi-judicial tribunal and to compliance with its decisions has been emphasized by members of the Committee itself and by commentators, all of whom agree that the Committee adheres to the basic requirement that its decisions be "reasoned" in the first instance. ${ }^{388}$ In addition, the Committee

the basis of the nature of their political beliefs," but declining to find a violation on the facts presented).

384. The Committee can achieve the same result by espousing progressive interpretations of the ICCPR in its general comments, which are intended as nonbinding guideposts for all states parties, and later relying on these interpretations in specific cases decided under the Optional Protocol. In this way, the Committee can introduce more rights-protective interpretations of the treaty without incurring full-scale political resistance by a particular state party. The Committee has followed this interpretive approach in at least one instance. See Brinkhof, U.N. GAOR at 129 (relying on an analysis of the state's treatment of conscientious objectors in the general comment on Article 18 in interpreting the obligation of the Netherlands to treat Jehovah's Witnesses and other objectors in the same fashion).

385. The European Commission of Human Rights adopted such a stance for European states that recognized the right of individual petition some years after ratifying the Convention. See ZWART, supra note 17 , at $134-38$.

386. See, e.g., E. v. Hungary, No. 520/1992, U.N. GAOR, Hum. Ris. Comm., 49th Sess., Supp. No. 40, Annex X, at 336, 339-40, U.N. Doc. A/49/40 (1994).

387. See id. at 341 (separate opinion of Chanet) (criticizing the majority's position declaring a communication inadmissible ratione temporis and stressing that the Committee's "decisions should bc guided only by the legal principles found in the provisions of the Covenant itself, and not by political considerations, even of a general nature, or the fear of a flood of communications from countries that have changed their system of Government" (emphasis added)).

388. As Christian Tomuschat (a former Committee member) states most cogently:

Legally, the views formulated by the [UNHRC] are not binding on the State Party concerned which remains free to criticize them. Nonetheless, any State Party will find it hard to reject such findings in so far as they are based on orderly proceedings during which the defendant Party had ample opportunity to present its submissions. The views of the [UNHRC] gain their authority from their inner qualities of impartiality, objectivity and soberness. If such requirements are met, the views of the [UNHRC] can have a far-reaching impact . . . .

Christian Tomuschat, Evolving Procedural Rules: The United Nations Human Rights Committee's First Two Years of Dealing with Individual Communications, 1 HUM. RTS. L.J. 249, 255 (1980). Erik Mose and Torkel Opsahl suggested as early as 1981 that "[i]f the Committee wishes to contribute to the development of the law of the Covenant through giving reasoned interpretations of its provisions on doubtful points," it must "state more elaborate reasons than in the earliest cases published." Erik Mose \& Torkcl Opsahl, The 
has always tried to present the factual and legal positions of both parties as fully as possible before advancing its own analysis. ${ }^{389}$ The core of the Committee's legal reasoning, however, occurs in its analysis of the Covenant's obligations and its application of these legal principles to the facts before it. $^{390}$ In this domain its reasoning has at times been both truncated and opaque, but it is steadily improving.

The Committee now gives reasons for its decisions in every case and addresses the competing arguments advanced by the parties. For example, the Committee has developed an increasingly sophisticated methodology for analyzing those Covenant rights and freedoms that governments may limit where "necessary" or where "necessary in a democratic society"391 to protect various vital interests such as public health, morals or the rights of others. ${ }^{392}$

Optional Protocol to the International Covenam on Civil and Political Rights, 21 SANTA CLAkA L REV 271, 325-26 (1981); see also ROBERTSON \& MERRILLS. supra nole 81. al 66 (“[1]f the Human Rughts Committee is to be regarded as an effective forum for venulatung complants, it is essentual that it should be proficient.").

389. Each decision of the Committee contauns. generally in order, the following elements the facts alleged by the author of the communication, the parties' posilions conceming admissibility, the reasoning behind the decision to declare the communication admissible, a detallod recital of each pany's arguments concerning the merits of the case, and lasuly, the Commutice's own examinituon of the ments See NowAk. supra note 15, at 708-09. As part of this examination, the Commitee often articulates the governing legal principles by referring to the text of relevant Covenant articles, its general comments interpreung those articles, and its prior decisions that provide a gloss on the Covenani's text. It then concludes with a determination that the Covenant has or has not been violated and, in the former case, with the appropnate actions that the state pary should take to remody such a volution. See id. at 709

390. Like other human rights treaties and constitutions, the Covenint does not always specify with precision the scope of a state pary's legal obligations; rather, nearly all of its provisions conlsin equivocal and contextual terms (such as "necessary" or "reasonable") that require interpretation and exposition through the varying fact patterns of individual cases to acquire a setuled meaning Even where the treaty specifies unambiguously what a state party must do or refrain from doung (such as the prohibulion against slavery or medical experimentation), the Committoe must determine whether the facts alleged fall within the stated legal principle.

391. The "necessary" or "necessary in a democrallc sociely" language appears in the ICCPR as a limitation on the following rights: the right to libeny of movement and freadom to choose residence. see Covenant, supra note 15, ar. 12, 999 U.N.T.S. at 176 ("necessary"). the nght to frecdum of thought. conscience, and religion, see id. ar. 18, 999 U.N.T.S. at 178 ("necessiry"): the freedom to hold opmuns without interference, see id. an. 19, 999 U.N.T.S. at 178 ("necessiry"); the nght of peaceable ussembly. see id. art. 21, 999 U.N.T.S. at 178 ("necessary in a democratic socicty"). and the nght of ireculom of association, see id. art. 22, 999 U.N.T.S. at 178 ("necessary in a democratuc society") See. e $g$. ad an 18(3), 999 U.N.T.S. at 178 ("Freedom to manifest one's religion or beliels may be subject to only such limitations as are . . necessary to protect public safety, order, health, or morals, or the fundumental nghts and freedoms of others." (emphasis added)); id. an. 21. 999 UN.TS al 178 ("No resinctions may be placed on [the right to peaceful assembly] other than those which are necessan in a democrattc socien in the interests of national security or public safety, public order (ordre public), the protection ot public health or morals or the protection of the rights and frealoms of others " (emphasis wdued))

392. Developing a workable jurisprudence to balance these competing interests is the hallmark of any successful human rights regime. Sir Rober Jennings wntes

[A] human rights regime that is indeed working-and not a paper idea-will be normally and mainly concerned not so much with the outrageous, but with highly technisul questions. $\mathrm{c} g$. concerning trade unions and their membership. the nght to work. police powers, the minutuse of due process of law, and the like.

Sir Robert Jennings, Hunan Rights and Domesic Law and Courts. in Protrctixo humas Rigrts Thk EURopean Dimension 295, 298 (Franz Matscher \& Herter Petzold eds.. 1988)

In early decisions, the Committec was reluctant to question the balante struck between individual liberties and other countervailing interests. See, e.g. Hertberg v Finland. No 1+/61. UN GAOR, Hum 
The same trend is evident in its interpretation of legal obligations not subject to limitation, such as Article 7's categorical prohibition of "torture or cruel, inhuman or degrading treatment or punishment,"393 and Article 10's unequivocal requirement that "persons deprived of their liberty shall be treated with humanity and with respect for the inherent dignity of the human person." ${ }^{\text {394 }}$ The Committee's initial attempt to give substance to these guarantees has been the subject of much scholarly criticism. ${ }^{395}$ More recently, however, the Committee has made significant, albeit less definitive, advances in specifying the scope of these human rights norms in its general comments $^{396}$ and in case law. ${ }^{397}$

\section{e. Judicial Cross-Fertilization and Dialogue}

Although in early decisions the Committee made few references to the

Rts. Comm., 37th Sess., Supp. No. 40, Annex XIV, at 161, 165, U.N. Doc. A/37/40 (1982) ('The Committee finds that it cannot question the decision of the responsible organs of the Finnish Broadcasting Corporation that radio and TV are not the appropriate forums to discuss issues related to homosexuality, as far as a programme could be judged as encouraging homosexual bchavior."). As its case law has evolved, however, the Committee has become increasingly likely to scrutinize with care the actions of states parties. See, e.g., Sohn v. Republic of Korea, No. 518/1992, Hum. Rts. Comm., 54th Sess., at 7, U.N. Doc. CCPR/C/54/D/518/1992 (1995) ("While the State party has stated that the restrictions were justified in order to protect national security and public order . . the Committee must still determine whether the measures taken against the author were necessary for the purpose stated."); Mukong v. Cameroon, No. 458/1991. U.N. GAOR, Hum. Rts. Comm., 49th Sess., Supp. No. 40, Annex IX, at 171, 181, U.N. Doc. A $49 / 40$ (1994) (indicating that the arrest and detention of a political opponent of the governing party was not "necessary for the safeguard of national security and/or public order" and thus violated the right to free expression); Ballantyne v. Canada, No. 359/1989, U.N. GAOR, Hum. Rts. Comm., 48th Sess., Supp. No. 40, Annex XII, at 91, 103, U.N. Doc. A/48/40 (1993) ("The Committee believes that it is not necessary, in order to protect the vulnerable position in Canada of the francophone group, to prohibit commercial advertising in English. This protection may be achieved in other ways that do not preclude the freedom of expression ....").

393. Covenant, supra note 15 , an. 7, 999 U.N.T.S. at 175.

394. Id. art. 10, 999 U.N.T.S. at 176.

395. Although the Committee considered numerous issues of ill-treatment under both articles, including incommunicado detention, solitary confinement, denial of medical treatment, and severity of prison conditions, commentators characterize its early opinions as "unhelpful, incomprehensible, or ambiguous" in that they fail "to develop a consistent, intelligible categorization of its views leading to a certain element of arbitrariness in its findings." MCGOLDRICK, supra note 17, at 381; see also THEODOR MERON, HUMAN RIGHTS LAW-MAKING IN THE UNITED NATIONS 111 (1986) (arguing that, unlike the ECHR and the European Commission of Human Rights, the UNHRC has "failed to elaborate on the concept of the prohibition [on torture] stated in Article 7'); NowAK, supra note 15, at 137 (describing the Committec's unwillingness to address violations of Article 7).

396. See General Comment 21/44 (rights of detainees), Apr. 6, 1992, reprinted in Nowak, supra notc 15, at 873-74; General Comment 20/44 (prohibition of torture), Apr. 3, 1992, reprinted in NowAK, supra note 15 , at $871-72$.

397. Compare Vuolanne v. Finland, No. 265/1987, U.N. GAOR, Hum. Ris. Comm., 44th Sess., Supp. No. 40, Annex X, at 249, 256, U.N. Doc. A/44/40 (1989) (discussing what constitutes inhuman or degrading treatment within the meaning of Article 7), with Thomas v. Jamaica, No. 321/1988, U.N. GAOR, Hum. Rts. Comm., 49th Sess., Supp. No. 40, Annex IX, at I, 3, U.N. Doc. A/49/40 (1994) (concluding, in an extremely terse opinion, that the facts presented "disclose a violation of articles 7 and 10, paragraph 1 " of the ICCPR). At least in part, the Committee's lack of detailed analysis in these cuses can be explained by the fact that the state party refused to cooperate with the Committee or to submit any evidence challenging the authors' allegations. See MCGoLDRICK, supra note 17, at 367. 
rulings of other supranational tribunals, within the last few years it has begun to engage in a dialogue with other such bodies-most notably the ECHR and the European Commission of Human Rights. The emergence of this dialogue provides additional evidence that the Committee understands the importance of communicating with other supranational tribunals concerning interpretive questions applicable to regional and global human rights regimes and of engaging in a common, mutually supportive enterprise.

To date, several different types of interaction between the European and United Nations human rights systems have occurred. Perhaps the most limited form of communication occurs where one of the parties cites to a prior decision of a regional tribunal as precedent in suppor of its claims before the Committee. ${ }^{398}$ Whether arguments influence the Committee is not always clear, because in the majority of decisions the members have not expressed a view as to the soundness of the regional tribunal's decision or reasoning. ${ }^{340}$

A second form of communication occurs when a litigant brings to the Committee a claim that a regional tribunal has already rejected. In such cases we might expect the Committee to explain its departure from regional practice, particularly where the civil and political rights at issue are protected in similar or identical language in the two treaties. In the two instances in which individuals received a favorable decision from the Committee after their claims were rejected by the European Commission of Human Rights, however, the Committee did not attempt to justify its departure from settled European practice. $^{400}$

The last form of interaction occurs in decisions in which the Committee actively considers the reasoning of regional tribunals in prior cases and attempts to harmonize or distinguish them. The most striking example of this phenomenon emerged in a line of cases analyzing whether prolonged detention on death row and its associated physical and psychological disabilities amounts

398. See, e.g., Celepi v. Sweden, No. 456/1991. UN GrOR. Hum Ris Comm, thh Sess. Supp No. 40, Annex X, al 165, 167, U.N. Doc. A/49/40 (1994) (reponing a state pany's cilation ol a deciston of the European Commission of Human Rights), Howard y Nurway. No $451 / 1991$. U N GAOR. Hum Rts. Comm., 49th Sess., Supp. No. 40, Annex X, at 146. 151-52. U N Doc N49/40 (1944) (reponung a state pany's citation of a judgment of the ECHR and a decision of the Commission). E IV V Netherlunds. No. 429/1990, U.N. GAOR, Hum. Rts. Comm., 48th Sess. Supp No 40. Annex XIII, at 198. 199-200. U.N. Doc. A/48/40 (1993) (citing to case law of the ECHR and the Commission). Bnnkhol $v$ Netherlands. No. 402/1990, U.N. GAOR, Hum. Ris. Comm., 48th Sess. Supp No 40. Annex XIll. 41 124, 128 , U. . Doc. A/48/40 (1993) (reporting a state party's citation of relevant "case law of the European Cummission")

399. In none of the decisions cited supra note 398 did the Commitle in tis examinstion of the ments refer expressly to the European tribunals' analyses

400. See Coeriel v. Netherlands, No. 453/1991, U N GAOR. Hum Ris Cumm, 49th Sess. Supp No 40, Annex X, at 23, U.N. Doc. A/49/40 (1994) (finding a violation of the Cuvensnt atter the Commission rejected the same challenge under the European Conventuon), Brmkliof. UN GAOR at 124 (sime), see also Casanovas v. France, No. 44I/1990. U.N. GAOR. Hum Ris Comm. 49h Sess. Supp No 40. Annex X. at 131, 133-34, U.N. Doc. A/49/40 (1994) (concluding. with only cursory analysis. that "nghts and obligations in a suit at law" in Article 14 of the Covenant encompass dismissal of civil servants trom employment, notwithstanding a contrary conclusion by the European Commission of Human Rights based on identical language in Article 6 of the Convention) 
to inhuman or degrading treatment. The ECHR concluded in Soering $v$. United Kingdom ${ }^{401}$ that such detention can amount to inhuman or degrading treatment, ${ }^{402}$ but the Committee has steadfastly refused to find a violation in similar circumstances. In its first two decisions on this issue, the Committee made no reference to the ECHR's judgment. ${ }^{403}$ But in Kindler $v$. Canada, ${ }^{404}$ the Committee, while reaffirming its position that death row detention is not a per se violation of the Convention, gave careful consideration to the ECHR's approach, adopting much of its reasoning while distinguishing the unique facts of Soering from the case before it:

In determining whether... the imposition of capital punishment could constitute a violation of article 7 , the Committee will have regard to the relevant personal factors regarding the author, the specific conditions of detention on death row, and whether the proposed method of execution is particularly abhorrent. In this context the Committee has had careful regard to the judgment given by the European Court of Human Rights in the Soering v. United Kingdom case. It notes that important facts leading to the judgment of the European Court are distinguishable on material points from the facts in the present case. In particular, the facts differ as to the age and mental state of the offender, and the conditions on death row in the respective prison systems. ... The Committee has also noted in the Soering case that ... there was a simultaneous request for extradition by a State where the death penalty would not be imposed. ${ }^{405}$

Such direct transjudicial communication provides further evidence that the Committee is behaving according to the checklist's prescriptions, although the

401. 161 Eur. Ct. H.R. (ser. A) at 41 (1989).

402. In Soering, the ECHR unanimously concluded that extradition of Jens Socring to face a capital murder charge in Virginia and to await execution on death row would violate the Convention's prohibition of degrading treatment or punishment. In accepting Soering's claim that exposure to the so-called "death row phenomenon" violated the treaty, the court examined several factors, including the six- to cight-ycar delay prior to execution, the conditions on death row, Soering's age and mental statc, the procedures available to challenge his conviction and sentence, and the possibility of extradition to another country where the death penalty had been abolished. See id. at $42-44$.

403. See Barrett v. Jamaica, Nos. $270 / 1988 \&$ 271/1988, U.N. GAOR, Hum. Rts. Comm., 47th Scss., Supp. No. 40, Annex IX, at 254, U.N. Doc. A/47/40 (1992) (refusing to find a violation in a 14-ycar stay on death row); Pratt v. Jamaica, Nos. 210/1986 \& 225/1987, U.N. GAOR, Hum. Rts. Comm., 44th Sess., Supp. No. 40, Annex X, at 222, U.N. Doc. AV44/40 (1989) (refusing to find a violation in a more than seven-year stay on death row). In Barrett, however, Committee member Christine Chanet cited to the Soering judgment in support of her conclusion that "[a] very long period on death row ... cannot exonerate a State party from its obligations under article 7 of the Covenant." Barreft, U.N. GAOR at 246 (separate opinion of Chanet).

404. No. 470/1991, U.N. GAOR, Hum. Ris. Comm., 48th Sess., Supp. No. 40, Annex XII, at 138, U.N. Doc. A/48/40 (1993).

405. Jd. at 151-52 (footnote omitted); see also Rodriguez v. Uruguay, No. 322/1988, U.N. GAOR, Hum. Ris. Comm., 49th Sess., Supp. No. 40, Annex X, at 5, 11 n.b, U.N. Doc. A/49/40 (1994) (distinguishing a state party's reliance on a judgment of the Inter-American Court of Human Rights by reference to a later advisory opinion of the Inter-American court and relevant decisions of the interAmerican Commission on Human Rights). 
Committee should ensure that it actually addresses the regional precedents cited to it.

\section{f. Form of Opinions}

Under the ICCPR, the adoption of views by the Committee requires a majority vote of the members present. ${ }^{406}$ Responding to a request by Sovietbloc states, however, the Committee decided in 1977 to resolve cases by consensus rather than by an official vote. ${ }^{407}$ Any member of the Committee has the right to call for a vote at any time, but "no formal vote has ever been taken." ${ }^{208}$ Although adoption of consensus as a method of work "has made an important contribution to the conciliatory atmosphere in the Committee and to the avoidance of politicization that would impair the efficiency of its work," ${ }^{409}$ it has also "reduce[d] the clarity and precision"10 of the Committee's views, which often reflect "the lowest common denominator of possible levels of agreement." ${ }^{411}$

In practice, the Committee's rules of procedure, which authorize members to append an "individual opinion" to a consensus decision, ${ }^{312}$ have mitigated some of the problems of the consensus approach. Although individual opinions were rarely used in the early years under the Optional Protocol, members have made increasing use of this practice recently, for both decisions on the merits and admissibility decisions. ${ }^{413}$ Moreover, Committee members have become far more likely to denominate their individual opinions as dissents rather than merely elaborating on the consensus position or articulating a concurring view. ${ }^{414}$

406. See Covenant, supra note 15. an. 39(b), 999 UN TS at 181

407. See NowaK, supra note 15, at 712 Rule 51 of the Rules of Procedure adopts the principle of majority voting but states in a footnote that Committee members should normally dtempt to resth decistons by consensus when this does not unduly delay the Commilec's work See id at $5+11+2$

408. Opsahl, supra note 17 , at 384 .

409. NOWAK, supra note 15, at 542.

410. MCGOLDRICK, supra note 17 , al 199

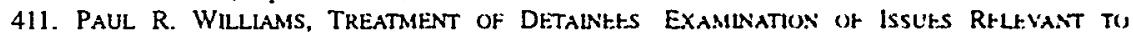
DETENTION BY THE UNITED NATIONS HUMAN RIGHTS COMMITTE 90 (19\%) Wiliams cununues The opinions of the activist members or members with strong and pantculat views sre nut expressed because they are seldom accepted by all the members, whereas the sew of the must reticent members are accepted as basic premises tor the views of the mure telle nembers, and Id. are thus agreed upon and presented in the repon

412. See Consideration of Communications Under the Ophonul Protocol. L'N GAOR. Hum RLs Comm., 48th Sess., Supp. No. 40, at 162-63. UN. Dox A/48/40 (1993)

413. See NowaK, supra note 15, at 712; see also MCGOLIBkiCK. supra nute 17, at 500 ("A number of the more recent views and decisions have occastoned substantial splits within the [Commitice even though this is not evident from the form in which the views appear ")

414. The move to a more juridical style of majority opinuon urutung is stnhingly evident in (wo 1993 decisions conceming Canada's extradition of two Amenisn fugutuses to fate the desth penalty in the United States. In Kindler v: Canada, No. 470/1991, U.N GAOR. Hum Ris Comm, t8th Sess, Supp Nu 40. Annex XII, at 138, 154-77, U.N. Doc. A/48/40 (1993), seven members of the 18-member Commutee hled dissenting opinions from some aspect of the consensus decision that the extradtion did nut violate the nght 
The dubious utility of maintaining a consensus procedure in light of such increasing use of individual opinions, the reduction of political tensions since the end of the Cold War, and the deleterious effect of consensus on the quality of the Committee's reasoning have led commentators to urge the Committee to adopt majority voting for all decisions. ${ }^{415}$ Given the heterogeneous array of states party to the Optional Protocol and the direct communication between the Committee and private parties, our analysis under the checklist would support such a reform.

\section{Factors Often Beyond the Control of States or Judges}

One of the essential characteristics of a global human rights regime is that any nation may seek to join and adhere to the regime's substantive obligations and enforcement procedures. The Covenant is precisely such a regime. The states that have ratified the treaty-in contrast to the states party to the Treaty of Rome or the European Convention on Human Rights--are at all stages of political, social, and economic development and have adopted widely divergent approaches to enforcing the rule of law domestically. This diversity of membership presents the Committee with challenges that its European counterparts are less likely to face, challenges that may ultimately circumscribe its potential for becoming fully effective but that it has nevertheless proven itself prepared to meet.

\section{a. Nature of Violations}

As might be expected from our checklist, the Committee's effectiveness in dealing with gross, systematic human rights abuses is no better than that of any other supranational tribunal. Indeed, the recently published list of states that have failed to provide follow-up information to the Committee includes countries that, as the Committee's views demonstrate, have engaged in gross human rights violations. ${ }^{416}$ Whereas the European Commission of Human Rights had to contend with the aftermath of a coup d'état in Greece, the Committee must contend with systematic repression and grave abuses

to life and the right to be free from cruel or inhuman treatment. And in $\mathrm{Ng} v$. Canada, No. 469/1991, U.N. GAOR, Hum. Rts. Comm., 49th Sess., Supp. No. 40, Annex X, at 189, U.N. Doc. A/49/40 (1993), cight members filed opinions dissenting in whole or in part from the Committee's conclusion that extradition to face death by gas asphyxiation, while not a violation of the right to life, breached the prohibition against cruel and inhuman treatment.

415. See, e.g., NoWAK, supra note 15, at 712 ("Since the East-West contlict has been overcome, the Committee should consider adopting its decisions on individual communications by majority voting."); WILLIAMS, supra note 411 , at $90-91$.

416. See 1995 Follow-Up Activities, supra note 312, at $97-98$ (providing a country-by-country breakdown of replies to the Committee's views and showing that states, such as Cameroon, Equatorial Guinea, Madagascar, Suriname, and Zaire, found to have committed serious human rights violations, had not submitted replies or had submitted inadequate replies). 
anywhere in the world. Even here, however, persistence may pay off. For example, after many years of nonaction, the Committee received a statement from Uruguay indicating that, after a change of government, it had released from imprisonment or offered amnesty to several individuals whom the Committee had determined were victims of serious human rights abuses. ${ }^{+17}$

\section{b. Autonomous Domestic Institutions Committed to the Rule of Law and Responsive to Citizen Interests}

The Committee exercises jurisdiction over a number of countries that affirmatively reject democratic government and that seek primarily to ensure the undivided loyalty of all government institutions to the prevaling political power. Likewise the Committee has jurisdiction over a number of other countries that simply fail, for a variety of historical, economic, and geographical factors, to impose any meaningful rule at all. We argued above that such countries are unlikely ever to comply with the judgments of a supranational tribunal; that states unable to maintain a rule of law domesucally by institutions responsive to the people would not provide channels or openings by which a supranational tribunal could even make itself heard, much less make its influence felt. ${ }^{418}$

On a macro level, the Committee's individual petition syslem may have little power to alter the regime type of the states parties or their commutment to the rule of law. But in building from case to case, the Committec can encourage greater compliance by states and the filing of additional claims for relief by targeting its decisions at private parties and disaggregated domestic government institutions seeking to resist either the centralization or the radical fragmentation of power. When the Committee issues a decision against one state, it must thus bear in mind that its views will be observed by government actors, individuals, and nongovernmental organizations in diverse states throughout the world.

Seeking to reach out to this audience, however, the Committee faces a new problem. As Committee member Rosalyn Higgins states: "What may be an appropriate and sensitive interpretation for the Western European democracies is not necessarily so for a global system embracing highly diverse politucal and economic systems. This is often strongly held by the Western members lof the Committee] themselves." 419 The existence of such a disparale constutuency creates a fundamental paradox for the Committee. On the one hand, if it sets substantive standards for the Convention that are too high, it risks an enforcement gap for states with less salutary human rights records. By contrast,

417. See MCGoldRICK, supra note 17, at 155 \& $223-24$ nn 338-41

418. See supra Subsection III.B.3.b. The inverse, however, did not hold The presence of such institutions committed to the rule of law does not guarantec complance with supranational fudgments 419. Higgins, supra note 8 , at 8 
the Committee must weigh the opposing danger that its decisions will fix a global minimum human rights baseline that is too low for many states with both a strong commitment to the rule of law and stringent domestic protection for constitutional liberties. ${ }^{420}$

To date, the Committee has, perhaps understandably, not articulated any overarching methodology for balancing these competing concerns. Instead, it has addressed each alleged violation of the Covenant on the facts before it, whether those facts concern shocking abuses of the right to life, liberty, and physical integrity, ${ }^{421}$ or whether they concern nuances of social security and other national welfare legislation that may only exist in industrialized nations. ${ }^{422}$ The Committee has indicated, however, that at least in some circumstances it will fix a human rights baseline that requires many states to take remedial measures ${ }^{423}$ or will not permit a government to justify a treaty. violation by reference to the social, political, or economic conditions prevailing in its territory. ${ }^{424}$ The Committee also has not shied away from openly wrestling with and often rejecting the arguments of states parties with comparatively strong human rights records. It thus appears that the Committee is willing to interpret the treaty to provide a level of rights protection more stringent than many states parties would prefer.

We strongly encourage the Committee to continue this course. The logic of the checklist suggests that in many cases "states" or "governments,"

420. See Bayefsky, supra note 300 , at $412-13$ (noting that the Committe "has tended to resolve the standard of compliance with international human rights law on a minimum common denominator" and concluding that the Optional Protocol "is in danger of becoming insignificant for individuals from states with generally good human rights records").

421. See, e.g., Kone v. Senegal, No. 386/1989, U.N. GAOR, Hum. Rts. Comm., 50th Sess., Supp. No. 40, Annex X, at 1, U.N. Doc. A/50/40 (1995) (discussing torture and arbitrary detention for four-and-onehalf years); Mojica v. Dominican Republic, No. 449/1991, U.N. GAOR, Hum. Rts. Comm., 49th Sess., Supp. No. 40, Annex X, at 142, U.N. Doc. A/49/40 (1994) (discussing disappeared persons and torture); Mika Miha v. Equatorial Guinea, No. 414/1990, U.N. GAOR, Hum. Rts. Comm., 49th Sess., Supp. No. 40, Annex IX, at 96, U.N. Doc. A/49/40 (1994) (discussing arbitrary detention and torturc).

422. See, e.g., Pepels v. Netherlands, No. 484/1991, U.N. GAOR, Hum. Rts. Comm., 49th Sess., Supp. No. 40, Annex IX, at 221, U.N. Doc. A/49/40 (1994); Neefs v. Netherlands, No. 484/1991, U.N. GAOR, Hum. Rts. Comm., 49th Sess., Supp. No. 40, Annex IX, at 120, U.N. Doc. A/49/40 (1994).

423. In Parkanyi v. Hungary, No. 410/1990, U.N. GAOR, Hum. Rts. Comm., 47th Sess., Supp. No. 40, Annex IX, at 325, 329-30, U.N. Doc. A/47/40 (1992), for example, the Committec held that limiting a prisoner's personal hygiene and outdoor exercise to a total of ten minutes per day violated Article 10 of the Covenant, which states that "[a]ll persons deprived of their liberty shall be treated with humanity and with respect for the inherent dignity of the human person," Covenant, supra note 15, art. 10, 999 U.N.T.S. at 176. According to a leading commentator on the Committee's work, "many countries in all regions of the world actually do not comply with this minimum standard." Nowak, UNHRC Activities, supra note 18. at 18 .

424. See Mukong v. Cameroon, No. 458/1991, U.N. GAOR, Hum. Rts. Comm., 49th Sess., Supp. No. 40, Annex IX, at 171, 176, U.N. Doc. A/49/40 (1994) (rejecting the state's contention that "the exercise of the right to freedom of expression must take into account the political context and situation prevailing in a country at any point in time"); id. at 180 (stating that "certain minimum standards regarding conditions of detention must be observed regardless of a State party's level of development"); see also General Comment 21/44, Apr. 6, 1992, reprinted in NowaK, supra note 15, at 873-74 (rejecting the claim that compliance with acceptable conditions of detention could be "dependent on the matcrial resources available" in a particular state). 
understood monolithically, will disregard the Committee no matter how flexible or contextual it tries to be. Only individuals or institutions who are independently resisting (or thinking of resisting) "government" policies and trying to establish an independent power base are likely to be heard. In such a setting it is vital that the Committee establish a universal baseline that legitimates these forces as part of a global community.

\section{c. Cultural and Political Homogeneity}

The Committee's ability to improve compliance with its judgments will prove an important test of the cultural and political homogeneity thesis. The Committee and the treaty it superintends are founded on a universalist premise: that basic rights and liberties transcend cultural and political differences by virtue of a shared humanity. Nevertheless, it may be true that institutions such as the Inter-American Court of Human Rights will prove more effective, as the ECHR has been, based in part on their greater legitimacy as the voices of particular geographic regions. Only time, and the emergence of more regional tribunals, will tell.

\section{Summing Up the Committee's Performance Under the Checklist}

Application of the checklist factors to the UNHRC reveals an institution struggling to carry out a wide variety of functions, both quasi-judicial and nonjudicial, with extremely limited resources and a rapidly increasing constituency of states parties, individuals, and nongovernmental actors. Although the Committee's effectiveness is nowhere near that of the ECJ and the ECHR, it is the similarities to, rather than the differences from, its effective European neighbors that we find most striking.

Even given the Committee's vastly broader scope of operations and the necessarily limited attention it can pay to individualized decisionmaking under the Optional Protocol, it is an institution struggling to achieve a distinctively judicial voice and to assert for itself, as have the ECJ and the ECHR, authority as the final arbiter of the meaning of the treaty regime it oversees. What is most noticeable is the Committee's effor, sometimes independently of states parties, to take many of the steps that we identify as likely to improve the effectiveness of its decisions: the improvements in the quality of its reasoning; the wider range of competing arguments aired by its increasing use of concurring and dissenting opinions; its willingness to take a position contrary to that of states parties in high-profile cases; its incremental and cautious advances in interpreting the treaty; its increased efforts to target an audience of individuals and their representatives as well as national courts; and its increasing dialogue with other supranational tribunals. These steps demonstrate a commitment to making the petition system more like a court and as effective 
a court as possible. Indeed, the Committee has even taken a position with respect to those variables over which it has no formal control, such as the legally binding character of its decisions and compliance with those decisions by states parties.

If the number of states party to the treaty and the number of communications filed with the Committee continue to increase, states parties will soon face a clear choice. If they wish the Committee to continue on its current trajectory, they can seek to alter those checklist factors within their control. Alternatively, they can hobble the Committee's operations by starving it of resources. The Committee itself, however, is likely to continue, within the limits of its abilities and resources, to transform its petition system and to emulate other supranational judicial tribunals in seeking to maximize its effectiveness.

\section{A PRESCRIPTION FOR ENHANCING THE EFFECTIVENESS OF THE HUMAN RIGHTS COMMITTEE: CONVERGING WITH THE ECHR IN A GLOBAL COMMUNITY OF LAW}

Having analyzed the UNHRC's performance in light of our checklist of factors correlated with "effective" supranational adjudication in Europe, the question remains how the Committee and states parties should proceed if they wish to create a more effective supranational regime for redressing human rights abuses. At the most general and perhaps simplistic level of analysis, a prescription is easy to articulate: The Committee and states parties should, within their respective spheres of competence, seek to enhance the Committee's performance with respect to all of the checklist factors. For the Committee, such a prescription would essentially counsel members to continue in the direction that they are already moving, reinforcing those characteristics that tend to make the Committee more "court-like." At its most extreme, such a prescription might include urging states to amend the Covenant and the Optional Protocol to create two supranational institutions: a nonjudicial body charged with monitoring states' obligations under the treaty's reporting process and a separate International Court of Human Rights with investigatory powers and the authority to issue binding decisions as a matter of international law.

Even if, however, such a revolutionary reworking of the Covenant were politically feasible (a dubious proposition at best), the balance of our checklist of factors provides a number of reasons to reject such an ambitious proposal. Although a bifurcated system would maximize many of the factors in the first and second clusters, the supranational judicial body it envisions might well find that compliance with its judgments falters because of shortcomings related to the third cluster of factors, in particular the existence of autonomous domestic institutions responsive to citizen interests, the commitment by states 
parties to the rule of law within their respective national legal systerns, and the grave nature of the violations.

One of the most important lessons of the European experience is that supranational courts and tribunals must move cautiously in their early years, striking a delicate balance between independence and deference, permitting states to adjust and respond to the mechanisms of supranational adjudication. Only after states develop a level of comfort with these mechanisms-and with complying with unfavorable outcomes in specific disputes-will it be feasible to enhance and extend the architecture of the system itself. ${ }^{.35}$ Accordingly, we believe that for the immediate future a far more modest proposal is in order, one that takes into account the Committee's existing and somewhat limited powers (both quasi-judicial and nonjudicial), the relatively poor record of compliance with the Committee's decisions, and the increasing importance of communication among judicial and quasi-judicial arbiters of individual rights disputes. Our proposal is thus only a first step in a longer-term strategy, the details of which should be reassessed as additional evidence becomes available.

Before elaborating on this proposal, we first describe the core elements of a "community of law" as it has developed in Europe, relating it to the various factors on the checklist. The following section discusses the expansion of this community through transjudicial communication and the emergence of actual transnational judicial institutions. Finally, we spell out the details of our proposal for the UNHRC to engage in a more structured and formal dialogue with the European human rights tribunals as the first step in an effort to build a global community of law.

\section{A. Elements of a Community of Law}

A community of law emerges alongside effective adjudication, simultaneously contributing to and reflecting the success of a particular tribunal. The ECJ has both drawn on and built a community of law among private parties, lawyers, and courts in the member states of the European Union; the ECHR has benefited from the foundations laid by the ECJ in exploiting and constructing a distinct but overlapping community of law among the same actors in the states party to the Convention. Once a community of law has been constructed, the various factors on the checklist have greater resonance.

425. The experience with Protocol No. 11 to the European Conventon aptly demunstrates this phenomenon. It was only after more than 30 years of supranitional review under the Convenuon that European nations agreed to make the nght of individual petition manditon; authonzing aggneved individuals to seek relief from the ECHR (rather than the Commission) in all cases See supra nutes $92-98$ and accompanying text. 
A fully constructed community of law has three attributes. First, it is a web of relations among subnational and supranational legal actors capable of interacting directly with one another. The ECJ used the Article 177 procedure to create links to lower national courts and to litigants, lawyers, and professors with a direct stake in European Community law. ${ }^{426}$ Similarly, the ECHR has benefited enormously from the innovation of the Optional Protocol allowing individuals direct access to the court. ${ }^{427}$ Checklist factors such as the availability of resources to publicize tribunal decisions, awareness of audience, judicial dialogue, and the limited nature of violations within liberal democracies all contribute to widening and deepening these channels of communication and action.

A second attribute of a community of law is that the interaction between subnational and supranational actors is consistent with the incentives of the individual participants. The ECJ provided incentives for individual litigants, their lawyers, and lower national courts to participate in the construction of the Community legal system. In the process, it enhanced its own power and the professional interests of all parties participating directly or indirectly in its business. ${ }^{428}$ Similarly, when the ECHR decides a case against a state, it is deciding for an individual litigant and her lawyer. It is thereby creating incentives for similarly situated litigants and lawyers to consider pursuing a remedy within the ECHR system. As lawyers become more familiar with the jurisprudence of the ECHR, a matter largely of the availability of translation, they become aware of how they can use these decisions to advance their clients' interests. ${ }^{429}$ At the same time, public interest groups and nongovernmental organizations with a global human rights agenda can find clients to bring test cases to the court to increase pressure for domestic political reform. ${ }^{430}$ Legal academics round out this network, actively pushing

426. For a further description of this web of actors, see Burley \& Matui, supra note 60 , at 58.

427. This description of the Optional Protocol is likely to resonate with political scientists more than with lawyers. From a legal perspective, the Optional Protocol is the instrument that gives substance and impact to the substantive provisions of the European Convention on Human Rights. Robertson and Merrills offer a typical account:

Under traditional international law the individual has no locus standi, on the theory that his rights will be championed by his government. But how can his government be his champion when ex hypothesi it is the offender? What is necessary, therefore, is to give the individual access to an international organ which is competent to afford him a remedy even against the government of his national State. The great merit of the European Convention on Human Rights is that it contains just such a procedure.

ROBERTSON \& MERRILLS, supra note 245, at 109.

428. For further discussion of the role of individual self-interest in the construction of the European Community legal system, see Burley \& Mattli, supra note 60, at 60 .

429. See DRZEMCZEWSKI, supra note 90 , at 305 .

430. Kathryn Sikkink describes such groups as forming "principled issue-networks," linked by shared values or principled ideas-beliefs about what is right or wrong. Kathryn Sikkink, Human Rights, Principled Issue-Nenvorks, and Sovereignty in Latin America, 47 INT'L ORG. 411, 411-12 (1993). Such a view is not inconsistent with the emphasis on interest in the text; such groups are simply using a supranational tribunal to pursue a different set of (nonmaterial) interests. 
domestic courts to take account of ECHR case law. ${ }^{431}$

Many of the same factors on the checklist that help create a web of subnational and supranational actors also appeal to the interests of those actors, including factors such as tribunal resources to publicize activities and awareness of audience. In addition, both casuist reasoning and dissenting opinions can permit a tribunal to speak civilly enough to the losing litigant to encourage her to sue another day. Finally, with respect to our third category of factors, liberal democracies are likely to provide a more hospitable environment for courts and private actors whose interests align with the promotion of a supranational rule of law and who have the freedom to pursue those interests.

A third and final attribute of a community of law is the self-awareness of all participants that they are operating in a nominally apolitical context. They should understand themselves to be linked by a common training and set of basic normative commitments to the autonomy and integrity of the legal process. While it is vital to appreciate the interest-based pillar of a community of law, the normative pillar is equally important. Factors on the checklist such as status as law, capacity for independent factfinding, the quality of legal reasoning, neutrality or autonomy from political interests, and incremental decisionmaking all acknowledge and bolster at least a formal distinction between law and politics that allows the community of law to be an insulated community, shielded from direct political interference.

In some sense, this division between the legal and the political is undoubtedly artificial. As just noted, participants in a community of law are aware that they are operating in a nominally apolitical context. In another sense, however, the political context is very real-as when the German government was prevented from overturning an ECJ decision contrary to its interests because of a domestic outcry that an action was "inconsistent with the principle of a Rechststaat, a state ruled by law.".332 More generally, the ECJ has benefited from both ignorance as to the long-term political significance of many of its legal rulings and the inability of member state governments committed to the domestic rule of law to justify interfering with an international tribunal operating in the same way as, and directly linked to, domestic courts. ${ }^{433}$ Equally relevant is the distinction between the treatment of decisions by the ECHR (and to a somewhat lesser extent the European Commission of Human Rights) and the treatment by the Committee of

431. See Polakiewicz \& Jacob-Foltzer, supra note 91, at 137 (desenbing Swiss tتademies" "filerce criticism" of the constitutional interpretation prohibitıng the federal court from judging the conformity of national laws by ECHR standards); see also Alter, supra note 261. at 111 (discussing the role of academic lawyers in pushing domestic courts to accept European Community law)

432. See Alter, supra note 261 , at 12 (describing the incident in detall)

433. For further elaboration of the significance of a "nominally dpolitucal context" to the construction of a community of law in the European Community, see Burley \& M1atti, supra note 60 . at $69-70$ 
Ministers, an explicitly political body charged with handling the more politically sensitive cases. In several states, the public prosecutor is empowered to ask domestic courts to quash decisions found contrary to the Convention by a decision of the ECHR, but not a decision by the Committee of Ministers. ${ }^{434}$ More generally, as Andrew Drzemczewski points out in his pioneering study, the courts in a number of countries simply pay less attention to the decisions of the Committee of Ministers, as determined by actual references to Committee versus ECHR decisions. ${ }^{435} \mathrm{He}$ attributes this discrepancy, in part, to "the political character of the organ itself.",436

In sum, a community of law is a community of interests and ideals shielded by legal language and practice. It is a community in which the participants-both individuals and institutions-understand themselves to be linked through their participation in, comprehension of, and responsibility for legal discourse. Equally important, participants are perceived by nonparticipants-politicians and other domestic institutions-as engaged in activity that should ordinarily be protected from direct political interference. A community of law thus offers channels through which some parts of the state can circumvent others, or whereby nonstate actors can bypass or at least pressure state actors. The desirability of these channels will depend on preexisting domestic politics - on the extent to which these various state and nonstate actors perceive themselves to be blocked by other state actors and have the freedom and desire to maneuver around them.

\section{B. Building a Global Community of Law}

Can a community of law be constructed at a global level? As the specific elements of the checklist and the more general attributes discussed above suggest, a true community of law is likely to be limited, at least in the short and medium term, to groups of countries or regions with a strong domestic tradition of the rule of law. Many judges around the world, however, are beginning to conceive of themselves as members of a global community, by virtue of either their role in implementing international norms or a common conception of their role and function within domestic legal systems and a common commitment to the rule of law.

434. See Polakiewicz \& Jacob-Foltzer, supra note 91, at 70 (discussing Belgium); id. at 135 (discussing Spain). On the other hand, in Austria, Switzerland, and the Netherlands, decisions of the coun and of the Committee of Ministers are granted binding status, while decisions of the Commission are treated as those of an intermediate body. See id. at 67 (discussing Austria); id. at 128 (discussing the Netherlands); id. at 137 (discussing Switzerland). Nevertheless, in countries in which courts are formally instructed to give equal weight to decisions of the court and the Committee of Ministers, in practice they favor the court.

435. See DRZEMCZEWSKI, supra note 90 , at $273,287,314,324$.

436. Id. at 273. 
In this context, an increase in judicial dialogue can reinforce the concept of a global sphere of law that is at least partially protected from direct political interference. As argued above, ${ }^{437}$ judges who look to the decisions of their fellow judges in other countries or regions are acknowledging engagement in a common enterprise in which the power of reason and the advantage of prior experience with a particular problem create a presumption of persuasion. In referring to and reinforcing one another, they create a space that is insulated, but not isolated, from politics, economics, and society.

Judges on national and supranational tribunals are citing each other, and by no means only in Europe. Commonwealth judges, the judges of national constitutional courts the world over, judges in fledgling democracies looking to their more established counterparts-all are talking to one another. Their conversations are hard to track but are beginning to attract the attention of scholars and litigants. ${ }^{438}$

Perhaps the paradigm case in this regard is a recent decision handed down by the South African Constitutional Court concerning the constitutionality of the death penalty. ${ }^{439}$ The decision contains an entire section titled "International and Foreign Comparative Law." $4+40$ This section systematically canvasses decisions relating to the death penalty from international tribunals such as the European Cour of Human Rights, the U.N. Human Rights Committee, the Inter-American Court on Human Rights, and the European and Inter-American commissions. In addition, the opinion reviews high-court decisions from the United States, India, Hungary, Canada, Germany, and Tanzania. Finally, the opinion takes account of decisions from two state courts in the United States, California and Massachusetts.

The court's reasons for conducting this survey were iwofold. First, it observed that the "international and foreign authorities are of value because they analyze arguments for and against the death sentence and show how courts of other jurisdictions have dealt with [the] vexed issue [of] the death penalty." "F41 "For that reason alone," the cour continued, "they require our

437. See supra Subsection III.B.2.e.

438. See GLenDON, supra note 203, at 158: Glenn, supra note 205. at 263 (discussing the use of nonbinding foreign legal sources as "persuasive authority"). Slaughter, supra nute 146, at 102-12 (discussing a variety of types of transnational judicial nouce). see also CONSTITUTIONALISM AND RIGHTS THE INFLUENCE OF THE UNTTED STATES CONSTITUTION ABROAD) (LOULS Henkin \& Alben J Rosenthal eds. 1989); INTERNATIONAL LAW DECISIONS IN NATIONAL COURTS (Thomas M Franck \& Gregory H Fox eds. 1996); Anthony Lester, The Overseas Trade in the American Bill of Righus, 88 CoLUM L REV 537. 541 (1988) ("When life or liberty is at stake, the landmark judgments of the Supreme Coun of the United States . . . are studied with as much attenuon in New Delh or Strasbourg as they are in Washington. D C. or the State of Washington, or Springfield, Illinors."). The Foderal Judicial Center and the Amencan Soctety of International Law also regularly publish a newsletter on transnational judsetal actuvity utled the International Judicial Obsenier.

439. See S. v. Makwanyane, 1995 (3) SA 391 (CC)

440. Id. at 17.

441. Id, at 18 
attention." 442 Second, these foreign decisions "may... have to be considered" 443 in light of the provision in the South African constitution that requires South African courts to "have regard to public international law applicable to the rights entrenched in this Chapter [of the Constitution],"' and that authorizes the courts "to have regard to comparable foreign case law." The court was thus unequivocal as to the value of comparative analysis as an important contribution to the deliberation process. Implicit in this claim, as argued above, is recognition of a community of courts around the world, units engaged in a common endeavor.

Such judicial conversations are not confined to paper. One of the signal developments in the transnational judicial world is the increase in face-to-face meetings among judges. A growing number of both formal and informal fora are dedicated to bringing judges together. The European supreme courts meet every two or three years and publish their proceedings. ${ }^{445}$ Following suit, the organization of "Supreme Courts of the Americas" was created in October 1995, at a meeting featuring representatives of the supreme courts of twentyfive countries of the western hemisphere. The delegates to the conference approved a charter with the stated aims of promoting and strengthening "judicial independence and the rule of law among the members, as well as the proper constitutional treatment of the judiciary as a fundamental branch of the state." ${ }^{446}$ These objectives are to be achieved through activities such as the provision of "a permanent link" between national judicial systems and various educational and technical assistance systems "designed to promote international judicial cooperation in the hemisphere."

The Washington-based Center for Democracy has also sponsored three conferences to date involving courts of "ultimate appeal" in Central and Eastern Europe and the former Soviet Union. ${ }^{448}$ These conferences have also been attended by judges and representatives of the ECHR, the European Commission, the Parliamentary Assembly, the Council of Europe, the U.N. Center for Human Rights, and the countries of Albania, China, Ethiopia, Germany, Italy, Slovakia, and the United States. ${ }^{49}$

Less formal meetings between judges around the world are sponsored by a variety of private organizations. The Mentor Group, based in Boston, has hosted a series of conferences between Justices of the U.S. Supreme Court and justices of the ECJ. New York University Law School also hosted a major

442. Id. (emphasis added).

443. Id. (emphasis added).

444. Id. (quoting S. AFR. CoNST. ch. III, art. 35(1)).

445. See Slaughter, supra note 146 , at 103 \& n.13.

446. Charter of the Organization of the Supreme Courts of the Americas att. II, $\S 2.1$.

447. Id. $\S 2.2$.

448. European Justices Meet In Washington To Discuss Common Issues; Problems, INT'L JUD. OBSERVER, Jan. 1996, at 2, 3.

449. See id. 
conference of judges from both national and international tribunals from around the world in February 1995. ${ }^{450}$ The organization InteRights, a nongovernmental organization based in London, has similarly dedicated itself to increasing contacts among judges in commonwealth countries. The aim is to develop awareness of comparative constitutional law, paricularly concerning the protection of individual rights. The founder of InteRights reports that judges who have attended its conferences often send each other decisions with cites to both international and other foreign tribunals. ${ }^{\text {st }}$ Finally, the American Bar Association's Central and Eastern European Law Initiative (CEELI) periodically sends American judges to various Central and Eastern European countries to assist with law reform, codification efforts, and judicial training. ${ }^{452}$

Personal contacts and professional cross-citation may ultimately build a sense of transnational judicial solidarity. Equally important, the resulting decisions can contribute to the development of a genuinely transnational or supranational body of law: a set of principles informed by and building on one another, textually and culturally differentiated as necessary but acknowledging the promise of universality. Such a phenomenon is particularly promising with respect to tribunals charged with interpreting and applying instruments that are themselves avowedly universal (though overlapping with their regional counterparts), such as the Universal Declaration of Human Rights ${ }^{453}$ and its progeny.

\section{A Modest Proposal: Dialogue and Convergence Between the European Human Rights Tribunals and the Committee}

\section{Thoughtful Convergence}

Against this backdrop, we offer the following specific proposal for the UNHRC. Although the numerous and diverse variables on our checklist make any single proposal necessarily incomplete in some respects, we believe that the Committee can enhance its effectiveness as a quasi-judicial tribunal by engaging in a dialogue with the ECHR and the European Commission of Human Rights ${ }^{454}$ as an important first step toward a broader effor to

450. Papers from the conference were subsequently published in INTEkNiATIONAL LAW DECISIONS IN NATIONAL COURTS, supra note 438.

451. Interview with Lord Lester, Founder, IntcRights, in Cambndge, Mass (January 25, 1995) The international human rights group is also developing a databise of commonwealth constututional jurisprudence. Id.

452. See CEELI Updare, ABA INT'L L. NEws (ABA. Washinglun, D C ). Summer $|\$ 9|$, at 7

453. G.A. Res. 217, U.N. GAOR, 3d Sess., al 71. U.N DOن A/810 (1948) [hereinalter Universal Declaration].

454. As noted above, see supra notes $92-98$ and accompanying text, althuugh the Cummisston will be phased out once all states parties have ratified Protocol No 11 to the Convention. its substuntual boxdy of case law will continue to be an impontant resource for the UNHRC for many years to come 
increase communication with other supranational tribunals and national courts over the interpretation of shared human rights standards. More specifically, we urge the Committee to harmonize its decisions with the case law of the European human rights tribunals. ${ }^{455}$ By striving to achieve a policy of thoughtful convergence with European jurisprudence, supplemented by informed divergence where there are justifiable and articulated reasons for doing so, the Committee can link its activities to an established community of law that has nurtured the existence and growth of effective supranational adjudication.

European human rights decisions are a natural point of departure for the Committee in many instances. The ECHR has decided hundreds of cases; the Commission, tens of thousands. "Today there remains hardly any substantive provisions of the Convention that have not been the object of a ruling" by these tribunals. ${ }^{456}$ Many of their decisions concern rights and freedoms whose texts are either identical or substantially similar to those protected by the Covenant. It would be a serious omission for the Committee to ignore this relevant body of precedents and the considerable judgment and experience they represent as it confronts similar difficult interpretive questions under the Covenant.

In several cases discussed above, ${ }^{457}$ the Committee has recently departed from settled European jurisprudence without any explanation or indication that it was doing so, thereby creating divergent interpretations of parallel treaty texts. Such divergences, particularly those that cannot be justified by arguments grounded upon textual or other differences between the two treaties, create the potential for forum shopping ${ }^{458}$ and tend to destabilize the previously harmonious relationship between regional and universal human rights

455. More than 25 years ago, A.H. Robertson anticipated the need to harmonize the workings of the two human rights regimes:

[I]t should not be beyond the wit of [hu]man[ity]-and more particularly, of lawyers-to work out adequate measures of harmonization of the two systems, the European and the universil, the more so as the fundamental objective of both of them is the same: the better protection of the rights of the common man and of the rule of law throughout the world.

A.H. ROBERTSON, THE INTERNATIONAL PROTECTION OF HUMAN RIGHTS 48 (1970). For years, however, the potential for differing interpretations of the Covenant and the European Convention remained only a theoretical problem. With few decided cases, there was little if any possibility for contlict in specific factual settings. As the preceding discussion demonstrates, however, the increased dialogue between the Committec and the European human rights tribunals has recently resulted in significantly divergent interpretutions of parallel rights and freedoms protected by both treaties.

456. Polakiewicz \& Jacob-Foltzer, supra note 91, at 65.

457. See supra Subsection IV.B.2.e.

458. Indeed, in the Coeriel and Brinkhof cases, individuals received a favorable decision from the Committee after the European Commission of Human Rights dismissed their cases. See Cocricl v. Netherlands, No. 453/1991, U.N. GAOR, Hum. Rts. Comm., 49th Sess., Supp. No. 40. Annex X, at 23, U.N. Doc. A/49/40 (1994) (finding a violation of the Covenant after the Commission rejected the same challenge under the European Convention); Brinkhof v. Netherlands, No. 402/1990, U.N. GAOR, Hum. Rts. Comm., 48th Sess., Supp. No. 40, Annex XII, at 124, U.N. Doc. A/48/40 (1993) (same). 
regimes. ${ }^{459}$ They also create confusing choices for national courts secking to take international human rights standards into account when construing analogous liberties protected by domestic constitutions.

The quality of the Committee's legal reasoning would also benefit from the Committee's acknowledging the existence of prior relevant European precedents and wrestling with the question of whether to follow or distinguish them. In doing so, the Committee is likely to engage in more rigorous theoretical and conceptual analysis to determine the contours of Covenant rights and freedoms and how they interact with the civil and political liberties protected by overlapping regional and universal human rights regimes. Open dialogue also helps to expose the weaknesses and the strengths of opposing positions and the competing values that undergird them. ${ }^{+\infty}$ Finally, dialogue encourages the Committee to participate in a global community of actors in a nominally apolitical process, thereby helping to insulate its rulings from overtly political influences. ${ }^{461}$

Although our proposal for convergence is directed primarily to the European human rights system, ${ }^{462}$ we by no means intend to discourage the Committee from consulting the rulings of the Inter-American Cour of and

459. One example of the danger of divergence can be found in the Eurupesn Convention for the Prevention of Torture and Inhuman or Degrading Treatment or Punishment. Noy 24. 1987. Eurup TS No. 126, 27 I.L.M. 1152 (1988). That treaty establishes the Committee Against Tunure to conduct factfinding investigations within states parties and to issue nonbunüing recommendations See Antionto Cassese, A New Approach to Human Rights: The European Com enton for the Pres ention of Torture. 83 AM. J. INT'L L. 128, 129-31 (1989). Although the case law of the ECHR and Commission will provide the Commituee Against Torture with a "source of guidance" in making its recommendations, the Commitee Against Torture is not precluded from consulting the "case law" develuped by other internationsl bodies. including the UNHRC. Id. at 138-39 The Commitce Aganst Tonure will be able to casry out its responsibilities far more easily if it can draw upon a coherent body of jursprudence in determinung the existence of a treaty violation. See id. al 135 (noung. with concern. the possibility that the Commutee Against Torture might adopt an interpretation of the Conventuon "that contlicted with the [ECHR's] jurisprudence on the matter, undermining the authonty of the ECHR and creatung undesirable confusion")

460. Thus, the Committee's ruling that a long period of delention on desth row is nut a per se violation of the Covenant was strengthened by its citstion to. and open distingushung of. the ECHR's Soering judgment, which found such detention to violate the Europesn Convention only stler dssessing the particular facts and circumstances of the case betore il. See supra noles $401-405$ and sicompunying text

In a recent decision, stx dissenting members of the Commillee stated that the majonty had retrealed from its prior commitment in Kindler 1 : Canada. No 470/1991. UN GAOR. Hum Ris Comm, 48th Sess., Supp. No. 40, Annex XII, at 138. U.N. Doc A/48/40 (1993), to ex.mme the tatts of each death row detention case and, as a result, had chaned an insulficiently nghis-protex(I)e course as compared to the European system. See Johnson v Jamatca, No. 588/1994. Hum Rts Comm. 56th Sess. al 1. 11-15 U . N Doc. CCPR/C/56/D/588/1994 (1996) (individual dissentung opinons of Chanel, Bhagustl. Cells, Puxas. Vallejo, and Urbina). Their dissenting vews compelled the mujonty to diknowledge "that ts junsprudence has given rise to controversy" and to "set out tis position in detal "/t at 6 We tind it signiltad that the Committee feels compelled to employ more ngorous legal reasoning when analyang an issue with respect to which it has engaged in an open dialogue with the ECHR

461. See supra Sections V.A-B.

462. The ECJ has developed its own human nghts junsprudence, but the lack of textual uverlap between the Treaty of Rome and the Covenant. the defining of ECJ human rights nurms pnnipally by reference to the constitutional traditions of the 15 European Unun member sidtes. and the aggressively teleological nature of ECJ jurisprudence, suggest that there will be tew ECJ cuses to which the Cummitec may profitably refer for guidance. 
Commission on Human Rights or the decisions of other treaty bodies charged with reviewing individual complaints concerning human rights abuses. ${ }^{463}$ Indeed, as the case law of these courts and quasi-judicial tribunals grows, we encourage the Committee to consult their relevant precedents in addition to European case law. Such consultation could lead to a richer and more nuanced transjudicial communication among all arbiters of civil and political liberties. It bears noting, however, that the Inter-American tribunals have been even less active than the Committee in addressing human rights complaints ${ }^{464}$ and that the U.N.-based treaty bodies are still in their infancy ${ }^{465}$ As a result, there are likely to be far fewer bases for comparison. ${ }^{466}$

\section{A Bounded Framework for Divergence}

Our proposal for informed convergence would undoubtedly be opposed by many states, especially those that are not members of any regional human rights regime. These states might argue that in ratifying the Covenant and the Optional Protocol they never intended to be bound by the decisions of the

463. The Committee on the Elimination of Race Discrimination and the Committce Against Torture are authorized to receive complaints from individuals alleging violations of the treaties they oversec. See Bymes \& Conners, supra note 12, passim. The Committee on the Elimination of All Forms of Discrimination Against Women cannot receive such complaints but has recommended that an optional protocol to the Convention on the Elimination of All Forms of Discrimination Against Women be drafted to permit them to be filed. See id. at 770-73; see also id. at 784-97 (reprinting the proposed optional protocol).

464. See ScotT Davidson, The InTER-AmERICAN COURT OF HUMAN Riohts 195 (1992) ("It is perhaps an abuse of speech to refer to the lack of use of the [Inter-American] Court's contentious jurisdiction. It is possibly more accurate to describe the prevailing situation as one of 'nonuse'."); James F. Smith, NAFTA and Human Rights: A Necessary Linkage, 27 U.C. DAVIS L. REV. 793, 839.40 (1994) ("The Inter-American Court's jurisprudence is neither extensive nor impressive but its achicvements so far demonstrate that its potential is enormous."); $c f$. Moravcsik, supra note 9, at 181-82 (discussing reasons for the relative ineffectiveness of the Inter-American tribunal).

465. See Byrnes, supra note 12, at 539 (noting that the Committee Against Torture's seven cases during the same time period were all declared inadmissible); Partsch, supra note 12, at 363 (noting that the Committee on the Elimination of Race Discrimination decided only two cases at the end of 1991).

466. By directing our proposal to the Committee, we do not mean to imply that the European tribunals should ignore the Committee's views. To the contrary, we believe that a two-way dialoguc between the human rights bodies will improve the reasoning and outcomes of both institutions. Indeed, litigants before the ECHR and the European Commission regularly consult the text of the Covenant and the Committce's case law to achieve a more coherent interpretation of the rights and freedoms protected by the Convention. See, e.g., Abdulaziz v. United Kingdom, App. Nos. 9214/80, 9473/81 \& 9474/81, 77 Eur. Ct. H.R. (scr. B) at 27 (1990) (Commission report) (citing and following the Committee's views that immigration controls may infringe the right to respect for family life); Silver v. United Kingdom, 51 Eur. Ct. H.R. (ser. B) at 218 (1987) (noting "the clear connection between Article 13 of the Convention and Article 2.3 of the International Covenant; their common intent; and the fact that those concerned in the drafting of the European Convention were dealing with concepts to be found in the United Nations Instruments" (tabulation omitted)); Young v. United Kingdom, App. Nos. $7601 / 76$ \& 7806/77, 39 Eur. Ct. H.R. (ser. B) at 55-56 (1984) (Commission report) (Kellberg, J., dissenting) (comparing the scope of freedom of association in the Convention to the scope of the right in other intemational instruments, including the Covenant). 
ECHR and the Commission and that any reliance on European jurisprudence is therefore illegitimate. ${ }^{467}$

We would reject any theory of convergence that recommended such slavish adherence to regional standards as to prevent the Committee from charting its own interpretive course for the Covenant. Our proposal for convergence is not nearly so absolute. To the contrary, we acknowledge that in many instances it will be both legitimate and necessary for the Committee to diverge from settled European case law. If the Committee is to diverge from an established European interpretation, however, it must bear the burden of justifying and explaining its departure. In the sections that follow, we spell out several possible bases for divergence and explore their legitimacy.

\section{a. Differences in the Rights Protected by the Two Treaties}

The most obvious ground for the Committee to decline to follow European precedent exists when the Covenant guarantees a right that is not found in the Convention. The Committee would have no need to consult regional case law for those civil and political rights that have no European analogue. ${ }^{+6 s}$

467. These states might also claim that a practuce that compels the Committec to consult regronal sources is itself a violation of the Covenant in that it confers powers on the Commitee not expressly specified in the text of the treaty. Several points undermine the force of this argument

First, although it is the general practice of international montonng bodies to rely solely on their own constituent treaties and decisional law, that practice has not boen unversally followed in the human nghts context. See DAVIDSON, supra note 464, at 57, 70, 193-95. M1tRON, supra nute 395. at 160-62 Eurupean human rights tribunals often refer to the texts of other human nghts trealtes and case law of uher human rights tribunals in determining the scope of the obligattons their own treaties impuse. and the ECJ has looked for inspiration to the jurisprudence of the ECHR when interpretung lundamental rights under Community law. See supra Subsection III.B.2.e.

Second, on numerous occasions, the Committe has already been requested by parties to adupt or diverge from a decision of the European tribunals. See supra nule 398 and atcompunying text in deciding whether or not to follow Europe's lead, the Committex was compelled to cunsider arguments based on European case law. Reference to such case law even where the parties have nor requested that the Committee do so would provide the Commiltec with an additunsl interpreuve metholulogy that would permit it to reach better reasoned decisions, even when it chooses to diverge trom a settled Eurupean interpretation.

Finally, for many years commentators have used the more developed case law under the Cunvention to forecast outcomes under the Covenant. There can be litle doubt that this body of scholarship has alteduly influenced the Committee's thinking. See, e.g., Higguns, supra note 8 . at 6 (nuting, as a Bnish member of the Committee, that the Covenant "does not exist in isolition and provistons in uther instruments can unavoidably intrude upon (the Committee's interpreuvel (unction"). Torkel Opsahl, The Coexistence Between Geneva and Strasbourg: Inter-Relationship of the Internattonal Cotenumt on Cual and Political Rights and the European Convention on Hunan Rights and Their Respecme Organs of Implementatun. 1991-1992 CAN. HUM. RTS. Y.B. 151, 164 (stating, as a Nonweglan member of the Commitiee. that in interpreting whether individuals will have access to a cour in admunistratuve ciases. "Il is sale to predict that [the issue] will cause many discussions, and many references to the Europesn seene in yedrs (o cume")

468. The rights and freedoms guaranted by the Covenunt that ane absent trom the Cunvention include the right of all peoples to self-determination, see Covenant, supra note 15. an 1. yy LNTS 4 173. the right of all individuals deprived of their libery to be treated with humanity and respect. see id ant 10.999 U.N.T.S. at 176; the right to recognition everywhere as a persun beture the law. see id an 16.999 U.N.T.S. at 177; the prohibition of propaganda for war and of incitement to disconmantion. see ad an 20. 999 U.N.T.S. at 178; the rights of the child, including protection trom discrimination. registration immediately after birh, the right to a name, and the nght to acyure a natuonality, see ad an 24,999 
Divergence is also justifiable where both the Convention and the Covenant protect the same right, but the definitions of that right differ in a substantial way. The Committee should consult European precedents when analyzing clauses in the Covenant that are identical or substantially similar to parallel texts in the Convention. But where the language defining the two provisions is not comparable-in other words where the Covenant is either more or less rights-protective than the Convention-the Committee need not defer to European case law. ${ }^{469}$ The degree of overlap for this cluster of "definitionally distinct" rights will, of course, necessarily vary with the specific language of each article.

\section{b. Divergence Where Object and Purpose Differ}

It has long been accepted practice under international law to resolve potentially troublesome questions of textual interpretation by reference to a treaty's "object and purpose." ${ }^{470}$ To the extent that the Convention and the Covenant enshrine different substantive goals, those differences may well be relevant to the Committee's analysis and, in certain contexts, can justify a departure from settled European case law. In what follows, we compare the similarities in the object and purpose of both treaties and then consider two ways in which they differ.

Both the European tribunals and the Committee agree that there is something special about human rights conventions that make them unlike many

U.N.T.S. at 179; and the right of ethnic, religious, or linguistic minorities to enjoy their own culture, praclice their own religion, or use their own language, see id. art. 27, 999 U.N.T.S. at 179.

This catalogue of rights was first identified by A.H. Robertson in 1968. See A.H. ROBkRTSON, HUMAN RIGHTS IN NATIONAL AND INTERNATIONAL LAW 36-40 (1968). We have omitted from this list the right to equality before the law and the equal protection of the laws protected by Article 26 of the Covenant. See Covenant, supra note 15, ant. 26, 999 U.N.T.S. at 179. While the Covenant guarantes an autonomous right to equality, the Convention protects against discrimination linked to other protected rights and freedoms. See NowaK, supra note 15 , at 461 . The test used by the European tribunals to ferret out invidious discrimination, however, is substantially similar to that applied by the Committee and thus can serve as an important point of consultation for the Committee in determining whether a state party's classification of similarly situated groups violates the Covenant.

We have also omitted from the list those Covenant articles that later were protected in a protocol to the Convention. See Protocol No. 4 to the Convention for the Protection of Human Rights and Fundamental Freedoms, Sept. 16, 1963, art. 2, 7 I.L.M. 978, 978 (1986) (protecting liberty of movement and choice of residence within a state); Protocol No. 7 to the Convention for the Protection of Human Rights and Fundamental Freedoms Concerning Civil and Political Rights, art. 1, 24 I.L.M. 535, 535 (1985) (hereinafter Protocol No. 7] (providing procedural safeguards for aliens under threat of expulsion).

469. Robertson identifies four clusters of rights with respect to which there are important definitional differences: (1) the right to life; (2) the right to a fair trial; (3) the right of marriage; and (4) political rights. See ROBERSTON, supra note 468 , at 30-36. With respect to fair trial and marriage rights, scveral provisions omitted from the Convention were subsequently included in one of its optional protocols. For example, the right to an appeal in criminal cases, the right to compensation for a miscarriage of justice, the principle of double jeopardy (ne bis in idem), and equality of rights and responsibilities between spouses "as to marriage, during marriage and in the event of its dissolution" werc all included in the seventh optionul protocol. See Protocol No. 7, supra note 468, arts. 2-5, 24 I.L.M. at 535-36.

470. Vienna Convention on the Law of Treaties, an. 31(1), opened for signature May 23, 1969, 1155 U.N.T.S. 331, 341 [hereinafter Vienna Convention]. 
other international agreements. Specifically, these instruments create enforceable rights for individuals, rather than simply obligations of states parties to one another. ${ }^{471}$ It follows that a state's surrender of sovereignty is not to be construed strictly, ${ }^{472}$ but rather must be given an autonomous international interpretation ${ }^{43}$ to make the rights and freedoms guaranteed effective rather than illusory. By construing the treaties in a rights-protective manner, both the tribunals and the Committee ensure that the protections established by the drafters do not become hollow promises honored more in the breach than in the observance. But beyond these important underlying similarities, there are important differences between the two treatues, differences that have become increasingly apparent as each institution's jurisprudence has developed.

\section{i. Reference to Democratic Principles}

The first difference concerns the European system's emphasis on the principles that prevail in democratic societies. The importance of these principles to the Convention can be gleaned from several sources: the requirement that all states parties must accept "the rule of law and democratic values," ${ }^{\prime 74}$ the text of the Convention itself, the preamble and numerous articles that refer to the phrase "democratic society," 776 and the case law of the ECHR and the Commission, which emphasizes that certain rights and

471. See Austria v. Italy, App. No. 788/60, 4 Y B Eur Conv on H R 116,135 , Eur Comm'n H R 1961) (stating that the Convention is not designed to create reciprocal obligstouns among states but ralhet to establish a "common public order" for Europe). Coxv Candus. No $539 / 1993 . \mathrm{Hum}$ Ris Comm. 52nd Sess., at 1, 18 U.N. Doc. CCPR/C/52/D/539 (1994) (Herndl and Sudi, concurnng) ("Admilledly, since the primary beneficiaries of human nghis treatues are not States but human beings. the protection of human rights calls for a more liberal approach than that normally applicable in the case of antiguuus pruvistons of multilateral treaties").

472. See J.B. v Canada. No 118/1982, UN GAOR. Hum Ris Comm. Alst Sess, Supp Niv to. Annex IX, at 151, 162, UN Doc. A/41/40 (1986) (Indwidual opunoms of Higgins. Lallah. M/sirummatts. Opsahl, and Wako) (stressing that the focus on object and purpuse is "especially impunant in a teaty for the promotion of human nghts, where limitation[s] of the exercist of nights are nut sesdils to be presumed"); see also NowaK, supra note 15. at Xxiv ("|G|enerally recognized rules of interpretulion tor human rights texts call for a liberal interpretation of nghts ('in dubio pro libertate') and a nastow interpretation of restrictions").

473. See Van Dusen v. Canada, No. 12/50. UN GAOR, Hum Ris Comm. 37th Sess. Supp . Vu t0. Annex XII, at 150, 155, U.N. Doc. A/37/40 (1982) The Commutec reasuned that the interpretation and application of the [Covenant] has to be based on the principle that the terms and concepts of the Covenant are independent of any particular national system of lat and of all dictionary definitions. Although the terms of the Covenant are derived trom long tradittons within many nations, the Committee must now regard them as having an atunomous meaning

Id.; see also Nowak, supra note 15, at Xxiv: Higgins, supra note 8. At S-6

474. Statute of the Council of Europe. May 5, 1949. pmbl. 87 L'NTS 103. 103, ad an 1. 87 U.N.T.S. at 103; id. an. 3, 87 U.N.T S. at 103

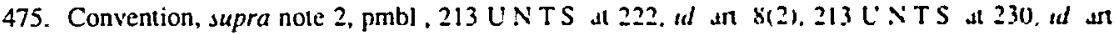
9(2), 213 U.N.T.S. at 230; $t$. ant. 10(2), 213 UNTS at 230. dd an 111(2). $213 \mathrm{~L} X \mathrm{~N}$ S 230 
freedoms and certain kinds of conduct are "hallmarks of democratic societies" that serve as touchstones for interpreting the entire Convention. ${ }^{476}$

The references to democratic societies in the Covenant are less prevalent, although by no means entirely absent. The treaty does not require states parties to adopt any particular political philosophy as a condition precedent to ratification. Nor does the preamble refer to democratic principles, although it does draw inspiration from the Universal Declaration of Human Rights, ${ }^{477}$ which itself refers to democratic societies in circumscribing the restrictions that states can impose on protected rights and freedoms. ${ }^{478}$ Significantly, however, three articles of the Covenant expressly condition restrictions on rights to those that are "necessary in a democratic society," 479 mirroring precisely the language of the Convention. ${ }^{480}$

Some commentators have argued that these limited references to democratic societies are sufficient to warrant the conclusion that democratic principles pervade the entire Covenant and should serve as a point of reference for every right it protects. ${ }^{481}$ Although civil and political rights have their roots in the liberal democratic tradition, the text of the Covenant belies the argument that democratic principles must inform every clause of the treaty. Indeed, for several articles, the phrase "democratic society" was expressly rejected by the drafters. ${ }^{482}$

The Covenant's limited references to democratic societies have important interpretive consequences. The Committee need not follow the ECHR's practice of using the traditions of democratic liberalism to infuse its interpretation of the entire treaty. Stated another way, there is no single

476. Young v. United Kingdom, 44 Eur. Ct. H.R. (ser. A) at 25 (1981). Although the ECHR and the Commission are still in the process of developing these principles, several important guidelines have already emerged. First, the court has placed special emphasis on the rights of minorities, noting that states partics must respect the principles of "pluralism, tolerance and broadmindedness" in their treatment of individuals. See id. Certain rights and legal doctrines have also been viewed as especially significant to the maintenance of democratic societies, including respect for the rule of law, freedom of expression and assembly, and the right to political representation. See MERRILLS, supra note 77, at 125-49.

477. Universal Declaration, supra note 453.

478. The Declaration provides:

In the exercise of his rights and freedoms, everyone shall be subject only to such limitations as are determined by law solely for the purpose of securing due recognition and respect for the rights and freedoms of others and of meeting the just requirements of morality, public order and the general welfare in a democratic society.

Id. art. 29 , at 75 .

479. See supra note 391 .

480. See supra note 475 and accompanying text.

481. See, e.g., Alexandre Charles Kiss, Pennissible Limitations on Rights, in ThE INTERNATIONAL BILL OF RIGHTS, supra note 15, at 290, 307 (arguing that "even in the limitations clauses where no explicit mention is made of a democratic framework, the idea of democracy is always underlying").

482. See NowaK, supra note 15, at 352 (discussing the dralters' omission of "democratic socicty" from limitations on freedom of expression and concluding that "[e]ven though this decision . . . in vicw of the great significance accorded freedom of expression for the functioning of democracy, may not seem understandable, it must nevertheless be taken into account in a system of interpretation of the Covenant"); see also Kiss, supra note 481 , at 306 (noting the drafters' rejection of the phrase from, inter alia, the Covenant's protection of freedom of thought, conscience, and religion). 
political vision toward which states pary to the Covenant must strive. ${ }^{483}$ Indeed, the essential point of a universal human rights treaty is to encourage all states, regardless of their political composition or stage of development, to ratify the agreement. Thus the Committee's reference to democratic principles is likely to be more limited and restricted to particular Covenant rights and freedoms.

Perhaps the most compelling case for the Committee to seek guidance from Europe exists for those Covenant articles in which the phrase "necessary in a democratic society" appears. For these protected rights and freedoms, the Committee should draw inspiration and suppor for its analysis from the case law of the ECHR and the Commission construing the same phrase in parallel Convention articles. For example, a state party attempting to limit freedom of assembly would have to demonstrate that its restriction of that right is consistent with such democratic principles as "pluralism, tolerance and broadmindedness," groups, ${ }^{485}$ and is narrowly circumscribed to keep the infringement of the

483. A telling counterexample to the practice we propose for the Commitce is the deciston of the Inter-American Court of Human Rights in its advisory opinuon in Compulson Wembershup in an Association Prescribed by Law for the Practice of Joumalsm. No OC-5/85. Nov 13. 1985, reprtmed in 7 HUM. RTS. L.J. 74 (1986). Like Article 19 of the Covenant, Antcle 13 uf the Inter-Amencan Cunvention guarantees freedom of expression but authorizes restnctions "necessary" to ensure several cumpeting interests. See id. at 82. Unlike Article 10 of the European Conventuon, huwever, these restrotuons need not be "necessary in a democratic society." Notwithstanding this omission, the Inter-Amencan Count louked to other articles of the Inter-Amencan Convention that reveal the primacy of demucratic prnnctples in interpreting the rights guaranteed by the treaty. See id at 83 After ciling to European case law. the court used democratic theory to bolster its conclusion that the Inter-Amencan Convention plates an extremely high value on free expression:

Freedom of expression is a comerstone upon which the very existence of a democratic society rests. It is indispensable for the formation of public opinion it is also a conderto seme qua non for the development of political partes, trade unions, scienufic and cultural sueielies and, in general, those who wish to influence the public. It represents, in shon, the means that enable the community, when exercising its options, to be sufficiently informed Consequenuly, $\|$ in be said that a society is not well informed that is not a socicly that is truly frec

1d. at 89. Thus, the court effectively read democratic udeals even into those conventuon articles where the phrase "democratic sociely" did not appear. Cf. DAvidSON, supra note 464 . at 195 (clamming that the approach of the Inter-Amencan Court "is clearly within the Wesiern liberal democratic tradituon which predicates a certain form of political, social and cconomic organisation. which in turn has implications tor both the interpretation and application of human rights").

484. Young v. United Kingdom, 44 Eur. C. H.R. (ser A) at 25 (1981) As Nowak nutes State measures to restrict frecolom of assembly must also comespond to a common. munumun democratic standard. This standard is lower in a unversal intemilional treaty than in a regional one, such as the ECHR. Nevertheless, the cniena of pluralism, tolerance. and broudmindedness mentioned by the European Cour of Human Rights in the Handyside case may be deemed valid as a general standard for democratic societies. This is accompaned by the principle of people's sovereignty, i.e., popular paricipation in the poltucal deciston-making process, and by the respect for and active protection of human rights, in parucular the requirement of democratic equality.

NowaK, supra note 15, at 379 (footnotes omitted) (ciung Handyside v United Kingdom. 24 Eur CI H R (ser. A) (1976).

485. See Platuform "Ärzte für das Leben" v. Austna, 139 Eur C H R (ser A) at 12 (1988) (holdıng that states parties have an affirmative obligation to ensure that demonstratuons promoting controversial or unpopular views are protected). 
right to an absolute minimum. ${ }^{486}$ Although there is less support for applying the same stringent democratic principles to those rights that states may limit where "necessary," the Committee need not dismiss the relevance of any gloss that the European tribunals have placed on these rights. Instead, the overlap of the word "necessary" in both treaties creates a powerful link that can provide the Committee with valuable insight determining the necessity of a restriction. ${ }^{487}$

\section{ii. Teleological Methods of Interpretation}

The ECHR's determination that the Convention is a "living instrument" to be construed "in light of present day conditions" is one of its most significant and well-documented interpretive tools. ${ }^{488}$ Far from being bound by the intent of the treaty's drafters, the court canvasses legal, social, and political developments in Europe as a supplementary means of interpreting open-ended clauses in the treaty and of ensuring that the clauses are relevant to modernday human rights problems. Where a large majority of European states have, over time, enlarged the scope of a protected right or narrowed the restrictions that may permissibly be imposed on its exercise, the ECHR has often found that a state not keeping pace with these reforms has violated the Convention. ${ }^{489}$

While the European tribunals continue their struggle to develop common European standards, the Committee has focused its attention primarily on defining the application of the Covenant's text to specific factual situations. ${ }^{490}$ Although the Committee has never expressly rejected the idea

486. See Dudgeon v. United Kingdom, 45 Eur. Ct. H.R. (ser. A) at 21 (1981) (holding that the court makes a final evaluation as to whether a government's arguments for restricting a right are relcvant and sufficient and "whether the interference complained of was proportionate to the social nced claimed for it").

487. As Nowak explains:

[T]he requirement of necessity is subject to an objective minimum standard, which may be subsequently reviewed by the Committee. The decisive criterion for evaluating whether this standard has been observed is ... not the principle of democracy but rather that of proportionality (Verhältnismäßigkeit) in the given case. Every interference thus requires a precise balancing between the right . . . and those interests to be protected by the interference. Interference is necessary only when its severity and intensity are proportional to a purpose listed in [the text].... The requirement of necessity underscores the principle that restrictions on Covenant rights are always exceptions and may therefore not become the rule. As a result, they are to be interpreted narrowly in cases of doubt.

NoWAK, supra note 15, at 211 (footnotes omitted).

488. E.g., Marckx v. Belgium, 31 Eur. Ct. H.R. (ser. A) at 19 (1979); Tyrer v. United Kingdom, 26 Eur. Ct. H.R. (ser. A) at 15 (1978).

489. Textual support for this teleological approach is found in the preamble to the Convention, which states that "the aim of the Council of Europe is the achievement of greater unity between its Members" and that one of the methods by which the aim is to be pursued is the "further realization" of a "common understanding and observance" of human rights in Europe. Convention, supra note 2, pmbl., 213 U.N.T.S. at 222; see also Cossey v. United Kingdom, 184 Eur. Ct. H.R. (ser. A) at 27 (1990) (Martens, J., dissenting) (citing to the preamble as a basis for the court to develop uniform European standards).

490. See, e.g., Gregory H. Fox, The Right to Political Participation in International Law, 17 YALB J. INT'L L. 539, 561 (1992) ("Unlike the U.N. Human Rights Committec, which rarely ventures beyond 
of a teleological method of interpretation, ${ }^{\$ 11}$ several factors militate against its adopting such an approach to the degree practiced by the ECHR and the Commission.

First, with one notable exception, ${ }^{49 z}$ nothing in the language of the Covenant authorizes the Committee to engage in such a practuce. Although it is undoubtedly the Committee's function to ariculate global human rights standards based on the language of the Covenant and its object and purpose, there is no basis for it aggressively to raise the global baseline in accordance with rights-enhancing law reforms.

Second, practical difficulties counsel the Committee against adopting an aggressively teleological interpretation similar to that employed by the European tribunals. Unlike the European system, which currently compnses 40 states with largely concordant legal systems, the 136 states party to the Covenant span a wide range of legal, political, social, and cultural traditions. Were the Committee to canvass all of these legal systems as a supplementary means of interpreting the rights contained in the Covenant, it would be unlikely to find the high degree of consensus that frequently occurs within the European regional system.

Instead, the Committee will likely adhere to more widely accepled methods of treaty interpretation, construing the Covenant in light of its text, object, and purpose, and where appropriate, the traviux preparatoires. ${ }^{\text {'3 }}$ Although subsequent practice of states parties is relevant to interpreting the Covenant, ${ }^{494}$ the Committee can authoritatively rely on such practice only where a large number of states have adopted it. Given that the pace of legal

treaty language in its decisions on paricipatory nghts. European (ribunals hase adduced extra-texiual participatory rights to reflect the common expectations of the parties to the European Cunvention ")

491. See MCGoldRICK, supra note 17, at 159 ("There has as yel been no parallel in the [Committee's] jurisprudence to the 'dynamic approach' to interpretation under the [Convention] "). of DaviDsox. supra note 464, at 138 ("[T]he Amencan Coun has had litule opponunity to engage in the kind of judicial legislation undertaken by its European analogue. This is not to say that elements of telcology are not evident in the jurisprudence of the Amencan Court ")

492. Aricle 6 of the Covenant, which tolerates applicauon of the Jeath penalty under nurrowly limited circumstances, states that "In]othing in this anicle shall be invoked to delay or to prevent the abolituon of capital punishment by any State Pany to the present Covenant" Covenant. supra nute 15, ant $6(6)$, 999 U.N.T.S. at 175. In its general comment on the nght to life, the Committec suggested that "would be especially vigilant in scrutinizing use of the death penalty and would exhon stites parties toward total abolition:

While it follows from arucle 6(2) to (6) that States parties are not obliged to abolish the death penalty totally, they are obliged to limit its use and, in particular. to abolish to other than for the "most serious crimes." Accordingly, they ought to consider reviewing thetr crumual laws in thus light ... The article also refers generally to aboltuon in terms which strongly suggest (paras $6(2)$ and (6)) that abolition is desirable. The Commitee concludes that all measures of abolthon should be considered as progress in the enjoyment of the right to life and should be reported to the Commitree. The Committe notes that a number of States have alteady abolished the death penalty or suspended is application.

General Comment 6/16, supra note 287 (emphasis addod). reprinsed un Nowik. supra nute 15. At 852

493. See Vienna Convention, supra note 470, an. 31(1), 1155 U N T S d38, see also Nowak. supra note 15 , at xxiii-xxiv.

494. See Vienna Convention, supra note 470, an 31(3)(b). 1155 UN T S at 337 
developments on a global scale is slow and that resort to a teleological method of interpretation may reduce Covenant standards to the level of its least rightsprotective states parties, ${ }^{495}$ the Committee's reliance on an expressly teleological approach is likely to be exceedingly rare.

\section{Divergence from a "European Gloss" on Human Rights}

The differing functions of the teleological method for interpreting the Covenant and the Convention raise one of the most troublesome areas of potential divergence: whether the Committee should follow European jurisprudence where the ECHR and the Commission have relied on uniquely European legal developments to expand the scope of Convention rights and freedoms. Arguably, where the tribunals have breathed new life into the Convention by relying primarily on European law reforms that have no analogue elsewhere on the planet, it would be improper for the Committee to impose the European human rights experience on the entire international community. ${ }^{496}$

It may be possible, however, for the Committee to divorce the "European gloss" on human rights from other beneficial aspects of the tribunals' reasoning

\section{Andrew Byrnes argues:}

Under a universal human rights treaty . . . to which more than 100 States parties with a wide variety of cultures, legal systems, stages of development are party, an international body might not so easily identify an actual or evolving international standard or, if it can do so, that standard may be heavily influenced by the least common denominator "drag"-the feeling that any decision must command a broad level of acceptance within the relevant constituency.

Andrew Bymes, Towards More Effective Enforcement of Women's Human Rights Through the Use of International Human Rights Law and Procedures, in HUMAN RIGHTS OF WOMEN: NATIONAL AND INTERNATIONAL PERSPECTIVES 189, 194 (Rebecca J. Cook ed., 1994) (emphasis added).

496. For example, several early rulings of the European Commission of Human Rights permitted European states to criminalize homosexual conduct between consenting adults. See, e.g., X. v. Fcderal Republic of Germany, 3 Y.B. Eur. Conv. on H.R. 184, 194 (Eur. Comm'n H.R.). In Dudgeon v. Unised Kingdom, 45 Eur. Ct. H.R. (ser. A) at 21 (1981), the European court changed direction and held that such laws violate the right of privacy. An important, although by no means exclusive, basis for this decision was the markedly changed views concerning homosexual conduct in the member states of the Council of Europe. The count reasoned that

there is now a better understanding, and in consequence an increased tolerance, of homosexual behavior to the extent that in the great majority of the member states of the Council of Europe it is no longer considered to be necessary or appropriate to treat homosexual practices . . . as in themselves a matter to which the sanctions of the criminal law should be applicd; the Court cannot overlook the marked changes which have occurred in this regard in the domestic laws of the member States.

Id. at 23-24.

Arguably, such a peculiarly European interpretation of human rights standards should not be persuasive for the Committee. For example, as of 1993, at least 74 countries around the world still criminalized homosexual conduct between consenting adults; moreover, states in Africa, the former communist nations, and other parts of the developing world are those primarily retaining these restrictions. See Rob Tielman \& Hans Hammelburg, World Survey on the Social and Legal Position of Gays and Lesbians, in THE THIRD PINK BOOK: A GLOBAL VIEW OF LESBIAN AND GAY LIBERATION AND OPPRESSION 150-51 (Aart Hendriks et al. eds., 1993). If the Committee were to rely unthinkingly on European precedents concerning homosexuality, it could well be accused of imposing a specialized view of human rights throughout the planet. 
and analysis. Rather than concentrating on the ECHR's use of European law reforms to interpret the Convention, the Committee might, through careful linedrawing, rely on European case law to assist it in developing an analytical framework for interpreting Covenant rights and freedoms. ${ }^{297}$ In addition, the Committee may validly rely on European case law that has expanded the Convention to include a level of rights protection already guaranteed by the Covenant. ${ }^{498}$ In this circumstance, the European teleological approach has merely brought the two human rights systems into harmony, thereby permitting the Committee to consult relevant European precedents when interpreting the Covenant.

\section{Divergence Where the Committee Improv'es on European Precedents}

A final basis for divergence may exist where the Committee has openly acknowledged the existence of relevant regional precedents but has concluded that their reasoning is unpersuasive and that a different interpretation is more consistent with the spirit of the Covenant. In such a situation, the Committee can legitimately depart from a European approach even where the texts of the two treaties are identical.

In determining whether it can improve upon European jurisprudence, the Committee may consider several factors: whether a relevant decision is an isolated case or part of a stable line of precedent that has been applied in a

497. The Committee appears to have followed this approach in its recent decision in Toonen : Australia, No. 488/1992, U.N. GAOR, Hum. Rts. Comm., 49th Sess. Supp No t0. Asnex IX. 4230.232 U.N. Doc. CCPR/C/52/D/488 (1994), in which tt concluded that crmmal sanctions on adult homoscxual conduct in Tasmania were an "arbitrary and unlawful interference with . pnvacy" under Article 17 of the Covenant. After construing the term "arbitrary" to require interferenees provided by law to be "reasonable in the circumstances," the Committee interpreted the requirement of reasonableness "to imply that any interference with privacy must be proportonal to the end sought and be necessary in the circumstances of any given case." Id. This analysis is strikingly similar to the ECHR's reasoning in the Dudgeon case. See 45 Eur. Cl. H.R. (ser. A) at $21-22$ (stating that interferences with pnvary must be "necessary in a democratic society," satisfy a "pressing social need," and be "proponionate to the legumate aim pursued"). Significantly, the Committee did not cite to the ECHR's case law, nor did it adopt the ECHR's teleological method of interpretation.

498. For example, although the Convention prohibits discrimination on the grounds of sex in precisely the same language that it prohibits other forms of discrimmation. the ECHR has concluded that the "advancement of the equality of the sexes is today a major goal in the member states of the Council of Europe. This means that very weighty reasons would have to be advanced before a difference of treatment on the ground of sex could be regarded as compatible with the Convention "Abdulazuz $y$ United Kingdom. 94 Eur Ct. H.R. (ser. A) at 38 (1985). Although the Commitce has yet to apply a similar heightened level of scrutiny for evaluating gender-based classifications, there is strong textual suppon for th to do so in addition to the two nondiscrimination clauses that include a reference to sex, see Covenant, supra note 15. an. 2(1), 999 U.N.T.S. at 173; id. an. 26, 999 U.NTS at 179. the Covenant contauns an adduonal guarantee "ensur[ing] the equal right of men and women to the enjoyment of all cuvil and political nghts set forth in the present Covenant." Id. ant. 3,999 U.N T.S. at 173 It would thus be appropnate for the Committee to view as highly persuasive decisions of the ECHR applying a stnngent standard of review to distinctions based on sex, inasmuch as the advancement of sexual equality is as important a goal among the Covenant's signatories as among the Council of Europe's member sijtes 
variety of factual circumstances; ${ }^{499}$ whether the case was decided by the Commission or the ECHR; ${ }^{500}$ whether the tribunals faithfully applied established doctrinal standards in deciding the case, ${ }^{501}$ and, if the same issue has been considered in the Inter-American system, whether its regional tribunals have adopted the European interpretation or diverged from that interpretation. ${ }^{502}$ Although divergence on this basis may be rare, the Committee should not be foreclosed from improving upon the tribunals' reasoning. Indeed, the ECHR and the Commission may eventually reconsider their approach in light of the Committee's conclusions, enhancing the two-way dialogue between the United Nations and Europe.

\section{CONCLUSION}

The twentieth century opened with a plethora of efforts to encourage peaceful settlement of disputes through judicial or quasi-judicial settlement, leading to the Permanent Court of Arbitration and ultimately the Permanent Court of International Justice. ${ }^{503}$ Over the course of the century many other tribunals have been created, both regional and global, general and issuespecific. Many are devoted to the resolution of classic "international" disputes between states. A new generation of tribunals more properly labeled "supranational" addresses disputes between private parties and national governments arising under international agreements. Even as parts of the globe plunge into a new round of conflict and atrocity, new proposals for war crimes tribunals and a permanent international criminal court have quickly followed. ${ }^{504}$ Existing mechanisms for international adjudication, such as

499. By applying a judicially created doctrine to a wide range of problems, the European tribunals can test the viability of that doctrine and adapt or modify it to changing circumstances. Prior to such adjudication, there will always be "grey areas" in the tribunals' jurisprudence. Cf. O'Boyle, supra note 91, at 285 (discussing current open issues in the ECHR's freedom of expression case law).

500. In several instances, the Commission's interpretation of the Convention was later rejected by the ECHR. See MERRILLS, supra note 77, at 15.

501. See, e.g., Colin Warbrick, Coherence and the European Court of Human Rights: The Adjudicative Background to the Soering Case, 11 MICH. J. INT'L L. 1073, 1084-85 (1990) (discussing two frecdom-ofexpression cases in which the court failed to adhere to established doctrine).

502. See, e.g., DAvidson, supra note 464, at 57, $193-94$ (discussing instances in which the InterAmerican court relied on reasoning of the European tribunals).

503. See Joseph Modeste SWEeney et al., The INTERNational Legal System 44-47 (3d ed. 1988).

504. See, e.g., MichaEl P. SChaRF, Balkan Justice: The StORY Behind the First INTERnational War Crimes Trial Since NuREmberg (1997); M. Cherif Bassiouni, From Versailles to Rwanda in Seventy-Five Years: The Need To Establish a Permanent International Criminal Court, 10 HaRv. HuM. RTS. J. 11 (1997); M. Cherif Bassiouni \& Christopher L. Blakesley, The Need for an International Criminal Court in the New International World Order, 25 VAND. J. TRANSNAT'L L. 151 (1992); Cristopher L. Blakesley, Obstacles to the Creation of a Permanent War Crimes Tribunal, 18 FLETCHER F. WORLD AFr. 77 (1994); Joel Cavicchia, The Prospects for an International Criminal Court in the 1990s, 10 DiCK. J. INT'L L. 223 (1992); Timothy C. Evered, An International Criminal Court: Recent Proposals and American Concerns, 6 PACE INT'L L. REV. 121 (1994); Michael P. Scharf, Getting Serious About an International Criminal Court, 6 PACE INT'L L. REv. 103 (1994). 
WTO and NAFTA panels, are adding supranational elements by increasing the access of private parties to the proceedings. Individuals are even being given a right of direct petition against international institutions such as the World Bank.

This renewed millennial faith in the ability of courts to hold states to their international obligations is more likely to be justified than the experience of the intervening decades might suggest. Two tribunals - the European Cour of Justice and the European Court of Human Rights-have been strikingly successful. They issue judgments that have a direct impact on the lives of ordinary Europeans, by securing them rights and privileges enshrined in international instruments and by holding their governments-signatories to those instruments-to their word. The two tribunals have compensated for their lack of direct coercive power by convincing domestic government institutions to exercise power on their behalf, through both direct persuasion and pressure from private litigants. We identify this relationship with domestic government institutions as the hallmark of "effective" supranational adjudication.

What lessons can be learned from the European experience? By consulting the analyses of close observers of these tribunals-scholars, lawyers, and the judges themselves-we develop a "checklist" of effective supranational adjudication. We divide it into three sets of factors: those that are within the control of the states party to an agreement establishing a tribunal, those that are within the control of the tribunal itself, and those that are often not subject to the control of either states or jurists. We rank the factors in each category roughly in order of relative impact. Overall, we intend the resulting list to be used both by scholars seeking to evaluate the effectiveness of other tribunals and by judges themselves seeking to improve their own effectiveness.

A striking feature of the checklist is the way in which the judges on the ECJ and the ECHR have exploited the opportunities granted them by the provision of supranational jurisdiction. They have built strong bridges to private litigants, creating a constituency for their judgments that is interested and able to pressure domestic government institutions to take heed and comply with those judgments. They also have forged direct relationships with different domestic institutions: The ECJ deliberately wooed national courts, and the ECHR earned support from courts, administrative agencies, and some national legislators. The majority of the checklist factors within the control of states or judges are linked to this process of constituency-building.

In a growing number of areas of international law, such as human rights law and trade law, individuals have a direct interest in calling their governments to account for violation of international obligations. Individuals also do not face the fears of a reciprocal response or diplomatic ramifications in other issue areas that often deter states from calling one another to account. In this context, the European experience of supranational adjudication augurs well for the prospect of "privatizing" public obligations by translating them 
into individual rights, creating a potential constituency that an adroit supranational tribunal can bring to life. Ernst-Ulrich Petersmann, for instance, argues that the "rights-based approach [of the ECJ and the ECHR], enabling self-interested individuals to enforce international guarantees of freedom and non-discrimination through the courts, . . . confirms that individuals . . may be the best guardians and promoters of rule-oriented international cooperation." 505

Beyond the language of interests, however, lies a deeper point, one that flows from changing conceptions of the state itself and of the sovereignty to which it is entitled. In democracies in which individuals are mobilized in support of the judgment of a supranational tribunal, compliance with that judgment becomes less a question of ceding sovereignty than of responding to constituent pressure. The state is no longer an interlocking set of government institutions in its domestic affairs, with sovereignty lodged in the people, and a unitary entity in its foreign relations, with sovereignty a fundamental attribute of its statehood. Instead, its internal and external face begin to mirror one another, as sovereignty becomes inextricably interwoven with accountability.

The checklist itself and our analysis of the way in which the checklist factors intersect with the unique features of supranational adjudication at least provide the basis for a positive answer to the question posed at the outset of this Article: whether it is possible to expand effective supranational adjudication beyond Europe. In the second half of this Article we apply the checklist to a human rights tribunal that is itself evolving from an explicitly nonjudicial entity into a quasi-judicial one. Over the past decade in particular, the U.N. Human Rights Committee has handed down more and better reasoned opinions, proved itself more willing to stand up to governments accused of human rights violations, and generally moved from a more diplomatic style of dispute resolution emphasizing compromise and avoidance of conflict to a more legal mode of consistent application of general principles. We evaluate this trajectory in terms of each of the factors on the checklist and conclude that the Committee is independently taking many of the steps we enumerate there: improving the quality of its legal reasoning; airing a wider range of competing arguments; being more willing to take a position contrary to that of states parties in high-profile cases; targeting an audience of individuals and their representatives as well as national courts; and increasing dialogue with those courts and with supranational tribunals. From this perspective, the Committee

505. Petersmann, supra note 54 , at 443 . David Wirth reaches a similar conclusion regarding the mechanism of the International Labour Organisation (ILO) allowing workers' and employers' organizations to participate with their governments as formal members of national delegations. See David A. Wirth, Legitimacy, Accountability, and Parmership: A Model for Advocacy on Third World Environmental Issues, 100 YALE L.J. 2645, 2664 (1991). The ILO gives these substate groups "access to a number of mechanisms to adjudicate nonobservance of binding standards established under ILO auspices." Id. These procedures, while far from being universally effective, "have been highly successful in encouraging ILO member statcs" adherence to binding treaty obligations like those in World Bank loan agreements." Id. 
is becoming more court-like and is enhancing its effectiveness within the explicit and implicit constraints and resource limitations imposed by the states subject to its jurisdiction.

Those constraints and limitations are very real, however. The universal scope of UNHRC jurisdiction necessarily means that the Committee oversees many different types of political regimes, including a number of governments that are not accountable to their citizens and that are apparently monolithic, with courts, administrative agencies, and legislatures tightly controlled by the reigning political authorities. These states seem relatively immune to a supranational tribunal's efforts to mobilize constituents from below. Notwithstanding these obstacles, however, we argue that the Committee should be able to replicate another dimension of the European experience: the construction of a "community of law." Participation in this community is open not to states per se, but to specific government institutions-particularly courts-that seek to challenge the prevailing political authorities through law.

A community of law has three principal elements: a network of subnational and supranational legal actors (lawyers, judges, and legal scholars) with independent channels of communication; a set of incentives encouraging these actors to interact with one another and to maximize the impact of supranational decisions; and a set of norms distinguishing law from politics in ways that promote an autonomous realm of law protected from direct political interference. Law may be the continuation of politics by other means, but the requirement that political interests be promoted through legal formulations and argument constrains the process. These constraints create a measure of autonomy for legal actors and an internal dynamic that achieves results other than those that would be achieved by direct political jockeying and bargaining.

Communities of law can be created on a national and a supranational basis. They can overlap and reinforce one another. An important mechanism for such reinforcement is judicial dialogue: the cross-citation of decisions by tribunals that have no direct relationship to one another. Invoking the reasoning of another tribunal that has no link to a particular case other than that its previous consideration and pronouncement on an analogous problem acknowledges the power of reason and the value of deliberation over time as well as across cultures. The result does not deny the imporance of local legitimacy and cultural diversity; nor does it assume that law can genuinely "float free" of the politics, economics, and cultural traditions of particular peoples. But it assumes the possibility of universal values and professional ideals and seeks to capture and reinforce a concept of transjudicial solidarity.

In this context, we conclude this Article with a specific proposal for linking the UNHRC to the human rights jurisprudence of the ECHR, as a contribution to a genuinely global dialogue among a wider range of supranational and international tribunals and domestic courts. According to this proposal, the UNHRC would actively seek convergence with ECHR reasoning 
in cases concerning rights and freedoms where the texts at issue are either identical or substantially similar to those protected by the Covenant. At the same time, however, a number of circumstances would prompt divergence from the ECHR's reasoning and results: (1) cases in which the rights protected by the European Convention and the Covenant differ on their face; (2) cases in which the Convention and the Covenant appear to enshrine different substantive goals; (3) cases in which the relevant ECHR precedent reflects a distinctive "European gloss" on the rights under consideration; and (4) cases in which the UNHRC concludes that it can improve on the relevant European precedent.

We advance this proposal in the spirit of the times. Part $\mathrm{V}$ begins with a review of a number of ways in which both national and supranational jurists around the world are increasing both formal and informal contacts with one another. The United States has traditionally been the most resistant to such efforts, but a more cosmopolitan outlook is emerging even here. Justice Sandra Day O'Connor, for instance, recently exhorted U.S. judges and lawyers to broaden their intellectual horizons, observing that ample historical precedent exists for "looking beyond American borders in our search for persuasive legal reasoning." 506 She pointed out that while U.S. judges have become "more inward-looking ... [o]ther legal systems continue to innovate, to experiment, and to find new solutions to the new legal problems that arise each day, from which we can learn and benefit." ${ }^{\circ 07}$ Vigorous and sustained dialogue between the UNHRC and the ECHR will add a supranational dimension to increasing transnational dialogue among judges. To the extent that these two supranational tribunals themselves draw on national traditions, they will also act as agents of increased cross-fertilization of national laws and judicial decisions. Most importantly, however, such interaction should strengthen both the awareness and the actuality of a common enterprise for all participating judges.

Its length notwithstanding, this Article is only a beginning. Supranational adjudication is a growing phenomenon, both in its pure form and in a number of variations in which private parties play increasingly direct roles in purportedly state-to-state litigation. ${ }^{508}$ A full-fledged theory of effective supranational adjudication could use the checklist as a point of departure for assessing the effectiveness of these other tribunals but would inevitably modify

506. Sandra Day O'Connor, Broadening Our Horizons: Why American Judges and Lawyers Must Learn About Foreign Law, 4 INT'L JUD. OBSERVER 2, 2 (1997).

507. Id.

508. Thus, for example, although disputes before ad hoc GATT panels were formally brought by one state against another, it has been observed that "there usually is some kind of a private disputc behind these GATT cases." Andreas F. Lowenfeld, Transcript of Discussion Following Presentation by Kelmeth $W$. Abbott, 1992 Colum. Bus. L. REv. 155, 161. Similarly, the newly adopted Agreement on Trade Related Aspects of Intellectual Property Rights states that intellectual property rights are "private rights," notwithstanding that only states may participate in the treaty's dispute resolution processes. Marrakesh Agreement Establishing the World Trade Organization, Apr. 15, 1994, Annex IC, pmbl., reprinted in 33 I.L.M. 1197, 1198. 
it in light of new data confirming or disconfirming our analysis. Commentators analyzing the track record or predicting the future behavior of other supranational and international tribunals and adjudicatory bodies identify many of the same factors that appear in our checklist, but they do not examine the relative impact of these factors within a systematic comparative framework. ${ }^{509}$ As such analysis proceeds, theoretical parsimony will be inevitably harder to achieve, giving ground to the nuance and detail of specific case studies. But a more developed theory, useful both for assessing the performance of existing supranational tribunals and generating recommendations on how to improve that performance, is a worthy and attainable goal.

"Effective supranational adjudication" may still seem a pipe dream to many, part of a utopian vision of global governance that is as likely to be realized as the Kantian vision of perpetual peace. Nevertheless, it has been achieved in large measure in at least one region in the world, for many distinctly non-utopian reasons. The search for those reasons and the effor to formulate them as preconditions is as likely to yield pessimistic prognoses for some regions as it is to bolster the prospects for others. Many of the factors on the checklist, even those within the power of the tribunals themselves or of the states that create them, may simply be unattainable. Nevertheless, we hope that the effort to distill such a checklist will help shift the debate over supranational adjudication away from the familiar tropes of realism versus idealism and toward the pragmatics of building regional and, perhaps, ultimately global communities of law.

509. See, e.g., Rochelle Cooper Dreyfuss \& Andreas Lowenleld, Two Admesements of the Uruguat Round: Putting TRIPs and Dispure SenlemenI Together. 37 VA J LNT'L L (furthomung 1997) (credung hypothetical cases to analyze general rules for appropriate resolution of disputes by panels interpreting the Agreement on Trade Related Aspects of Intellectual Propeny Rights and noing such tatturs as the quality of legal reasoning, incremental development of jurisprudence. dislogue with the World Intellectus! Propeny Organization, the composition of the panel, and the background of the members), Loper, supra nule 12 , at 172, 178 (surveying the first two years of dispulc resolutuon under NAFTA and noung that ceratn decisions were "thorough and well-written" and that pantl opinons oflen contancd indwidual cuncurnng and dissenting opinions): Phulip Nichols, GATT Doctrme. 36 VA J INT'L L 379. 388 n 40. 396, 394. 425. 431, 455 (1996) (providing a comprehensive analysis of pre-L'ruguay Round GATT panel decistuns and identifying such factors as the compostion of panels and backgrounds of members, unanimity ul Lecisions. the number of complaints filed and cases decided, and the consislency and reasuning ut punel dex isiuns). Jeffrey Waincymer, Reformulated Gasolme Under Reformulated WTO Dispute Somlement Procedures Pulling Pandora out of a Cliapeau?, $18 \mathrm{MICH}$ \& INT'L L 141, 143. 165.66 (19\%) (andly/ng the hirst decision by the WTO appellate body and stressing such factors as "approsthes to legal reasuning" and "citation of ICJ and other international law cases"). Daniel S Sullusn. Note. Effectu e litiernational Dispute Settlement Mechanisms and the Necessan Condinon of Luberal Democrac. 81 Gito L J 2369 (16)3) (linking the effectiveness of supranational dispute sethliment to the political tegume-ly pe (I) states parties). see also Shell, supra note 12, at $911-22$ (proposing that prudte patties be graticd standmg telore IVTO panels); Schleyer, supra note 12, at 2275 (same) 
